\title{
Expedition 345 summary ${ }^{1}$
}

K.M. Gillis, J.E. Snow, A. Klaus, G. Guerin, N. Abe, N. Akizawa, G. Ceuleneer, M.J. Cheadle, Á. Adrião, K. Faak, T.J. Falloon, S.A. Friedman, M.M. Godard, Y. Harigane, A.J. Horst, T. Hoshide, B. Ildefonse, M.M. Jean, B.E. John, J.H. Koepke, S. Machi, J. Maeda, N.E. Marks, A.M. McCaig, R. Meyer, A. Morris, T. Nozaka, M. Python, A. Saha, and R.P. Wintsch²

\section{Chapter contents}

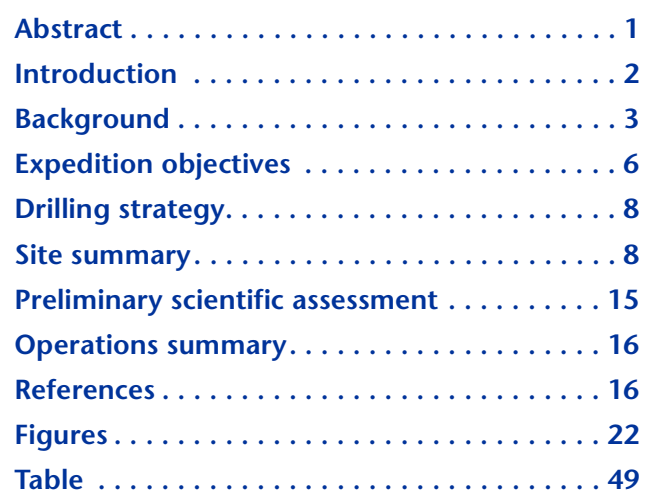

${ }^{1}$ Gillis, K.M., Snow, J.E., Klaus, A., Guerin, G., Abe, N., Akizawa, N., Ceuleneer, G., Cheadle, M.J., Adrião, Á., Faak, K., Falloon, T.J., Friedman, S.A., Godard, M.M., Harigane, Y., Horst, A.J., Hoshide, T., Ildefonse, B., Jean, M.M., John, B.E., Koepke, J.H., Machi, S., Maeda, J., Marks, N.E., McCaig, A.M., Meyer, R., Morris, A., Nozaka, T., Python, M., Saha, A., and Wintsch, R.P., 2014. Expedition 345 summary. In Gillis, K.M., Snow, J.E., Klaus, A., and the Expedition 345 Scientists, Proc. IODP, 345: College Station, TX (Integrated Ocean Drilling Program).

doi:10.2204/iodp.proc.345.101.2014

'Expedition 345 Scientists' addresses.

\section{Abstract}

Integrated Ocean Drilling Program (IODP) Hess Deep Expedition 345 was designed to sample lower crustal primitive gabbroic rock that formed at the fast-spreading East Pacific Rise (EPR) in order to test competing models of magmatic accretion and the intensity of hydrothermal cooling at depth. The Hess Deep Rift was selected to exploit tectonic exposures of young EPR plutonic crust, building upon results from Ocean Drilling Program Leg 147 as well as more recent submersible, remotely operated vehicle, and nearbottom surveys. The primary goal was to acquire the observations required to test end-member crustal accretion models that were in large part based on relationships from ophiolites, in combination with mid-ocean ridge geophysical studies. This goal was achieved with the recovery of primitive layered olivine gabbro and troctolite with many unexpected mineralogical and textural relationships, such as the abundance of orthopyroxene and the preservation of delicate skeletal olivine textures.

Site U1415 is located within the Hess Deep Rift along the southern slope of the intrarift ridge between 4675 and $4850 \mathrm{~m}$ water depths. Specific hole locations were selected in the general area of the proposed drill sites (HD-01B-HD-03B) using a combination of geomorphology, seafloor observations, and shallow acoustic subbottom profiling data. A total of 16 holes were drilled. The primary science results were obtained from coring of two $\sim 110 \mathrm{~m}$ deep reentry holes (U1415J and U1415P) and five single-bit holes (U1415E and U1415G-U1415I). Despite deep water depths and challenging drilling conditions, reasonable recovery for hard rock expeditions (15\%-30\%) was achieved at three 35-110 $\mathrm{m}$ deep holes (U1415I, U1415J, and U1415P). The other holes occupied during this expedition included three failed attempts to establish reentry capability (Holes U1415K, U1415M, and U1415P) and six jet-in tests to assess sediment thickness (Holes U1415A-U1415D, U1415F, and U1415L).

Olivine gabbro and troctolite are the dominant plutonic rock types recovered at Site U1415, with minor gabbro, clinopyroxene oikocryst-bearing gabbroic lithologies, and gabbronorite. These rocks exhibit cumulate textures similar to those found in layered mafic intrusions and some ophiolite complexes. All lithologies are primitive, with Mg\# between 76 and 89, falling within the global range of primitive oceanic gabbros. Spectacular modal and grain size layering was prevalent in $>50 \%$ of the recovered core, display- 
ing either simple or diffuse boundaries. Magmatic foliation largely defined by the shape-preferred orientation of plagioclase and olivine is moderate to strong in intervals with simple modal layering but weak to absent in troctolitic intervals and largely absent in intervals with heterogeneous textures and/or diffuse banding. The abundance of orthopyroxene found in these primitive rocks was unexpected and deviates from the standard model for mid-oceanridge basalt crystallization. Localized preservation of delicate skeletal olivine grains suggests that on a small scale the lower crust was not subjected to significant hypersolidus or subsolidus strain.

Metamorphic mineral assemblages record cooling of primitive gabbroic rock types from magmatic conditions $\left(>1000^{\circ} \mathrm{C}\right)$ to zeolite facies conditions $\left(<200^{\circ} \mathrm{C}\right)$ associated with Cocos-Nazca rifting and exposure at the seafloor. Greenschist to subgreenschist facies alteration dominates and is most pervasive in olivinerich lithologies and within zones of brittle fracturing and cataclasis. Amphibolite facies metamorphism is not abundant in comparison to the upper gabbro at the Hess Deep Rift.

Core recovered at Site U1415 originated at a stratigraphic level at least $2 \mathrm{~km}$ beneath the sheeted dikeplutonic transition and thus represents intervals of the lower half to one third of the EPR plutonic crust. The orientation of the magmatic fabrics and magnetic inclinations of the core suggest that Site U1415 is composed of a series of blocks (30 to $>65 \mathrm{~m}$ vertical thickness) formed by mass wasting. Sampling three or four blocks of relatively fresh rock proved advantageous, as it facilitated observations of two distinct types of layering and troctolite units with varying grain size, lithologic associations, and textures.

The results of the IODP Hess Deep Expedition 345 provide a reference section for primitive fast-spreading lower crust that did not exist before. The mineralogical and textural observations show that in several respects the Oman ophiolite is not the ideal model for fast-spreading ocean crust and call into question some aspects of both of the end-member accretion models that were to be tested. This highlights the necessity of ocean drilling to address questions related to the origin and evolution of the lower ocean crust.

\section{Introduction}

The accretion of new ocean crust at mid-ocean-ridge spreading centers is one of the fundamental processes of Earth evolution. Understanding the nature of the crust and mantle and the underlying geologic processes that form them is an ongoing fundamental justification for drilling in ocean basins (Hess, 1960; see Ocean Drilling Program [ODP] science plan at www.odplegacy.org/program_admin/

long_range.html and Integrated Ocean Drilling Program [IODP] Initial Science Plan at www.iodp.org/ isp). At mid-ocean-ridge spreading centers, magmas are delivered to the base of the crust and pass through a lower crustal filter on their way to higher level magma chambers and eventual eruption as mid-ocean-ridge basalt (MORB) (see review by Klein, 2007). These melts evolve through complex processes of crystallization and deformation in the lower plutonic crust, most of which take place within the first million years of lithospheric evolution (see Coogan, 2007, for a broad overview). Our knowledge of these lower crustal processes has been strongly influenced by ophiolite studies (e.g., Pallister and Hopson, 1981; Nicolas, 1989), but only direct observation of modern ocean crust can inform a definitive understanding.

Two drilling approaches have been used to directly observe modern plutonic ocean crust: total penetration, whereby holes are initiated in the upper lavas with eventual penetration into the plutonic crust (ODP Site 1256), and offset drilling, in which holes are directly initiated in tectonic exposures of the plutonic crust, thus bypassing the upper crust entirely (e.g., ODP Sites 735 and 894 and IODP Hole U1309D). The concept of offset drilling is that by drilling relatively short holes that start at a variety of crustal levels, a composite section could be constructed that equals or even improves upon the results that could be obtained through a total crustal penetration. This approach is particularly effective for areas such as the Hess Deep Rift where use of complementary technology (remotely operated vehicles and submersibles) allows for regional-scale characterization of the crust, providing a comprehensive geological framework on which to hang the offset sections.

The structure of the ocean crust, and in particular the nature of the plutonic sequence, varies significantly for mid-ocean ridges formed at different spreading rates (Fig. F1). The classic view of a layered, continuous ocean crust, the so-called Penrose model (Fig. F1A), is expected to be representative of fast-spreading crust (Anonymous, 1972). The structure of slow-spreading crust varies with position along the ridge, with segment centers having a thicker crustal component than segment ends (Fig. F1B, F1C) (Dick, 1989; Cannat, Karson, Miller, et al., 1995). Ultraslow-spreading crust also shows signifi- 
cant variation in the thickness and rock type distribution with depth (Dick et al., 2003). However, the plutonic section of fast-spreading crust has been sampled in relatively few localities (Gillis, Mével, Allan, et al., 1993; Perk et al., 2007). To date, ocean drilling has recovered some significant sections of the ocean crust, both by total penetration holes (i.e., Deep Sea Drilling Program [DSDP] Hole 504B and ODP Hole 1256D) and offset drilling legs with numerous shallow to deep holes (e.g., ODP Legs 118, 147, 153, 176, and 209 and IODP Expedition 304/ 305) (Fig. F1).

The principal objective of IODP Expedition 345 was to sample the young primitive plutonic crust that formed at the fast-spreading East Pacific Rise (EPR), filling in a major lithologic gap in our sampling of the lower oceanic crust (blue rectangle in Fig. F1A). The expedition took advantage of exposed primitive gabbroic rock at the Hess Deep Rift. Current knowledge of Hess Deep crustal sections (see "Previous research at the Hess Deep Rift"), in combination with geophysical studies of the EPR, drilling of the plutonic crust of slow-spread crust, and studies of ophiolite complexes, allows for the formulation of a series of specific questions that may be tested by drilling at Hess Deep.

\section{Rationale for Hess Deep drilling}

The Hess Deep Rift was selected for Expedition 345 as it is the best-studied tectonic window into fastspreading oceanic crust. An unprecedented geological framework for fast-spreading crust is available based on extensive investigation of contiguous sections of the mid- to upper crust along the Northern and Southern Escarpments and sections of the midto lower crust and uppermost mantle along the rift valley floor (Francheteau et al., 1990; Karson et al., 1992, 2002; MacLeod et al., unpubl. data), and Leg 147 (Gillis, Mével, Allan, et al., 1993) (see "Previous research at the Hess Deep Rift"). These geological relationships, coupled with investigations of recovered samples, provide a comprehensive framework for the igneous, metamorphic, and deformation processes active at the fast-spreading EPR.

\section{Background}

\section{Crustal accretion models for fast-spreading crust}

Two end-member models for crustal accretion at fastspreading ridges have emerged from geophysical observations in the modern oceans and geological evidence derived from the Oman and other ophiolites (e.g., Nicolas et al., 1988) (Fig. F2). Seismic reflection studies at the EPR identify axial melt lenses $<1-2 \mathrm{~km}$ below the seafloor that are $\sim 1 \mathrm{~km}$ wide and a few tens of meters thick (Detrick et al., 1987; Hooft et al., 1997; Kent et al., 1990; Singh et al., 1998). A low-velocity zone that underlies axial magma chambers (AMCs) is interpreted to be partially molten, containing <20\% melt (e.g., Dunn et al., 2000). The internal structure of this region, such as the distribution of melt and its geometry, is not well constrained because of, for example, the uncertainties of converting compressional wave velocity with varying melt distribution. Locally, melt has been shown to pool at or below the Mohorovicic discontinuity (Moho), both on- and off-axis, and also within the lower crust off-axis (Garmany, 1989; Crawford and Webb, 2002; Durant and Toomey, 2009; Canales et al., 2009).

The geological framework for the crustal accretion models is largely based on the Oman ophiolite, in which there are significant contrasts between upper and lower gabbro in terms of its composition and deformation fabrics (e.g., Pallister and Hopson, 1981; Nicolas et al., 1988; Coogan et al., 2002b). The lava sequence, sheeted dike complex, and upper gabbro have mafic phases and calculated melt compositions that are not consistent with direct derivation from liquids in equilibrium with the upper mantle, as expressed, for example, by their Mg\#. In the lower gabbro, compositions are more primitive and range between those of the upper gabbro and melts in equilibrium with the upper mantle.

The first crustal accretion model is the gabbro glacier model (Henstock et al., 1993; Quick and Denlinger, 1993; Phipps Morgan and Chen, 1993), in which most crystallization occurs within a shallow melt lens and the resulting crystal mush subsides downward and outward by crystal sliding to generate the full thickness of the plutonic layer (Fig. F2A). The latent heat of the plutonic crust is largely lost to the overlying hydrothermal system through the melt lens on-axis. The alternative sheeted sill model (Kelemen et al., 1997; Korenga and Kelemen, 1997, 1998; MacLeod and Yaouancq, 2000) predicts that almost all of the lower crust crystallizes in situ in a sheeted sill complex, such that melts pond repeatedly as they are transported through the lower crust, with crystallization occurring from the Moho to the upper melt lens (Fig. F2C). The heat delivery to the lower crust is so high that conductive mechanisms alone cannot remove that heat, requiring extensive hydrothermal cooling along the sides of the crystal mush zone to remove the latent heat of crystallization on-axis (Chen, 2001). Hybrid models have also been proposed, in which some crystallization occurs in the $\mathrm{AMC}$ and some in situ within the plutonic crust (Fig. 
F2B) (Boudier et al., 1996; Coogan et al., 2002b; Maclennan et al., 2004). In fact, both end-member models require some portion of each process. In the gabbro glacier model, the melt lubricating subsiding crystals, allowing them to flow, would crystallize in the deeper crust, and in the sheeted sill model, more rapid cooling at shallow levels in the crust requires some crystal subsidence to prevent the AMC from solidifying (e.g., Maclennen et al., 2004).

Predictions for a range of chemical and physical parameters for the two end-member models are shown in Figure F3. The gabbro glacier model predicts nearly constant $\mathrm{Mg \#}$ for plutonic rock and cumulate minerals throughout the plutonic sequence, with most crystallization occurring in a nearly steadystate shallow magma chamber. The predicted increase in Mg\# with depth in the sheeted sill model is based on partial in situ crystallization of magmas in the lower crust and upward migration of evolved liquids. The two models predict different changes in strain with depth, with increasing strain in the gabbro glacier model as a consequence of lower crustal flow.

Predictions for the response of the hydrothermal system are critical to the distinction of the two models. The sheeted sill lower crust requires deep, on-axis convective cooling to remove the latent heat, resulting in a higher hydrothermal fluid flux and a greater overall intensity of hydrothermal alteration in the lower crust than does the conductively cooled gabbro glacier model. Theoretical studies focusing on the axial heat budget have investigated the viability of the lower crustal accretion models (Sleep, 1975; Morton and Sleep, 1985; Chen, 2001; Cherkaoui et al., 2003; Maclennan et al., 2004). Both accretion models, as well as hybrids of the two, have been shown to be viable (e.g., Cherkaoui et al., 2003; Maclennan et al., 2004); however, the lack of observational constraint on key input parameters (e.g., permeability) make the interpretation of these thermal models uncertain.

How do the predictions of the crustal accretion models compare with our current knowledge of gabbroic sequences from fast-spreading ridges? Shallow-level gabbros sampled at Hess Deep, Pito Deep, and Site 1256 all show evolved compositions (Hékinian et al., 1993; Perk et al., 2007; Wilson et al., 2006; Koepke et al., 2011). At Pito Deep, however, nearly all gabbro from $>300 \mathrm{~m}$ below the base of the sheeted dike complex is much more primitive than at the same structural level at Hess Deep (Hanna, 2004; Perk et al., 2007). This compositional difference suggests that primitive, mantle-derived magma may be transported to shallow depths with little fractionation occurring along the way (Pito Deep) and that crystal fractionation and postcumulus reactions may produce evolved rocks at these depths as well (Hess Deep and Site 1256) (Perk et al., 2007). Tests of the predictions for hydrothermal processes are less complete because of the absence of observations of deeper level gabbros. What has been documented to date are rapid cooling rates in the shallow-level gabbros (Coogan et al., 2007) and calculated heat fluxes across a contact aureole (Gillis, 2008) that are indicative of substantial heat loss through the axial melt lens. Collectively, observations from Site 1256 and Hess and Pito Deeps suggest that the competing accretion models may both be viable, when spatial and/or temporal variability in magmatic processes along the EPR are considered (Coogan, 2007).

\section{Geological setting of the Hess Deep Rift}

The Hess Deep Rift is located in the vicinity of the Galapagos triple junction (ridge-ridge-ridge), at the intersection of the Cocos, Nazca, and Pacific plates (Fig. F4) (Hey et al., 1972, 1977; Holden and Dietz, 1972). The north-south-trending EPR is spreading at $130 \mathrm{~mm} / \mathrm{y}$, and the east-west-trending Cocos-Nazca Rift is propagating westwards toward the EPR at a rate of $42 \mathrm{~mm} / \mathrm{y}$. Reconstruction of the bathymetry in this region suggests that the current configuration of the Galapagos triple junction has been active for at least 10 m.y. (Smith et al., 2011). The Galapagos microplate was initiated at $1.5 \mathrm{Ma}$. Although the cause is not known, this initiation may be related to the formation of seamounts in the vicinity of Dietz Deep (Fig. F4) (Lonsdale, 1989; Smith et al., 2011; Schouten et al., 2008).

The EPR at the latitude of the Hess Deep Rift is made up of many short, first-order ridge segments separated by second-order overlapping spreading centers (Lonsdale, 1988). Thus, the crust exposed at the Hess Deep Rift likely formed within a short segment, perhaps at a segment end (Lonsdale, 1988). Reconstructions of the EPR flanks indicate several recent episodes of migrating offsets, suggesting that the crust exposed in the Hess Deep Rift could have formed on the western side of the EPR (Lonsdale, 1989; Smith et al., 2011; Schouten et al., 2008). New high-precision zircon dates of between 1.420 and 1.271 Ma for gabbroic rock from the intrarift ridge (Rioux et al., 2012) support this reconstruction, as they place this gabbro to the west of the EPR at the time of its formation.

The Hess Deep Rift is a complex region that formed by deep crustal extension ahead of the westward propagation of the Cocos-Nazca spreading center. The surface expression of rifting is first evident $\sim 30$ $\mathrm{km}$ from the EPR where, from west to east, two $5 \mathrm{~km}$ wide, east-west grabens merge and the rift broadens to $\sim 20 \mathrm{~km}$ and deepens to $>5400 \mathrm{~m}$ at Hess Deep 
(Fig. F5). An intrarift ridge rises to 3000 meters below sea level (mbsl) north of Hess Deep. Further to the east, the tip of the Cocos-Nazca spreading center starts to build a volcanic ridge that spreads at 55 $\mathrm{mm} / \mathrm{y}$. Uplifted rift escarpments contiguous with the EPR crust rise to depths $<2200$ mbsl north and south of the rift.

A composite section of EPR crust and uppermost mantle is exposed along the rift escarpments and valley floor of the Hess Deep Rift. Multichannel reflection profiling along the EPR flanks north of the Northern Escarpment indicates a crustal thickness of 5-5.5 km (Zonenshain et al., 1980). The thickness of the upper crust ranges from 0.7 to $1.2 \mathrm{~km}$ (Karson et al., 2002), so the plutonic crust is $\sim 3.8-4.8 \mathrm{~km}$ thick.

The subseafloor geology of the western end of the intrarift ridge and its southern slope has been investigated by on-bottom seismic and gravity surveys (Ballu et al., 1999; Wiggins et al., 1996). Results of these geophysical surveys, in combination with the regional geology, have led to a model whereby coherent crustal blocks were unroofed by detachment faulting and block rotation on listric normal faults (Francheteau et al., 1990; Wiggins et al., 1996; MacLeod et al., 1996b; Pariso et al., 1996). The viability of this model has been called into question based on new high-resolution bathymetric data collected as part of the JC21 site survey cruise for Expedition 345 (C.J. MacLeod et al., unpubl. data). Revised models consider the role of mass wasting linked with rifting (Ferrini et al., 2013) and dynamic uplift associated with the Cocos-Nazca spreading center (MacLeod et al., 2008).

The results of Expedition 345 substantiate the role of mass failure as being a dominant process along the southern slope of the intrarift ridge (see below).

\section{Previous research at the Hess Deep Rift}

The Hess Deep Rift exposes contiguous sections of the mid- to upper crust along the Northern and Southern Escarpments and sections of the mid- to lower crust along the rift valley floor. The EPR upper crustal sections include laterally extensive outcrops of the lava and sheeted dike complex that are normal, depleted MORB (Stewart et al., 2002). Lateral variation in the thickness and internal structure of the volcanic sequence and sheeted dike complex are attributed to temporal variations in magma supply (Karson et al., 2002). Hydrothermal alteration of the upper crust is largely focused in the sheeted dike complex, where the dikes are variably altered to amphibole- or, locally, chlorite-dominated assemblages (Gillis, 1995; Gillis et al., 2001).
Shallow-level gabbros are exposed along the Northern Escarpment and at the summit of the western end of the intrarift ridge. The northern scarp exposures, which directly underlie the sheeted dike complex, are dominated by gabbronorite, with lesser amounts of Fe-Ti oxide and amphibole gabbro, varitextured gabbro, olivine gabbronorite, Fe-Ti oxide gabbronorite, and rare tonalite (Hanna, 2004; Kirchner and Gillis, 2012; Natland and Dick, 1996). The shallow-level gabbro has a wide range in $\mathrm{Mg \#}$ (mean $\mathrm{Mg} \#=0.56$; range $=0.30-0.76$ ), with gabbronorite being the most primitive and Fe-Ti oxide \pm amphibole gabbro being the most evolved end-members (Hanna, 2004; Kirchner and Gillis, 2012; Natland and Dick, 1996). Rock types exposed at the summit of the western end of the intrarift ridge are similar to the Northern Escarpment, with gabbronorite, oxide gabbronorite, gabbro, olivine gabbro, and patches of pegmatitic amphibole gabbro (Fig. F6) (Gillis, Mével, Allan, et al., 1993; Hékinian et al., 1993: Lissenberg et al., 2013). This shallow-level gabbro is slightly less evolved (mean $\mathrm{Mg} \#=0.58$; range $=0.35-0.68$ ) than Northern Escarpment shallow gabbro, with the most evolved samples located along the northern margin of the intrarift ridge, close to dolerite interpreted as sheeted dikes (Blum, 1991; C.J. MacLeod, pers. comm., 2009; Pedersen et al., 1996; Gillis, Mével, Allan, et al., 1993). In both locations, shallow gabbroic rock lacks modal layering but locally contains lithologic boundaries identified by grain size variation (Gillis, Mével, Allan, et al., 1993; Hékinian et al., 1993).

Plutonic rock exposed along the central and eastern region of the southern slope of the intrarift ridge, between 4400 and $5400 \mathrm{mbsl}$, include gabbro, gabbronorite, olivine gabbro, and lesser troctolite (Fig. F6) that are, on average, more primitive than the summit of the intrarift ridge (mean $\mathrm{Mg} \#=0.71$; range $=0.39-0.85)($ Blum, 1991; C.J. MacLeod, pers. comm., 2009). As with the shallow-level gabbro, modal layering has not been documented for the deeper gabbro. It is important to note that the stratigraphic depth of this more primitive gabbro is not known, as these rocks likely migrated downslope by mass wasting processes.

A weak to strong magmatic foliation defined by the shape-preferred orientation of plagioclase laths is found in some samples from throughout the gabbroic sequence (Hékinian et al., 1993; Coogan et al., 2002a; Gillis, Mével, Allan, et al., 1993; MacLeod et al., 1996a). Reorientation of sections of the shallow gabbros in ODP Hole $894 \mathrm{G}$ to geographical coordinates shows that foliation is steeply dipping (mean $\operatorname{dip}=69^{\circ}$ ) with a nearly north-south orientation par- 
allel to the EPR, and that there is a steeply plunging lineation (MacLeod et al., 1996b). Measurements of the anisotropy of magnetic susceptibility in samples also show that a magnetic fabric is parallel to the plagioclase fabric (Richter et al., 1996). Crystal-plastic deformation is rare throughout the gabbroic sequence, with minor undulose extinction and very rare deformation twins in plagioclase.

Hydrothermal fluid flow throughout the entire gabbroic sequence was dominated by pervasive fluid flow along grain boundaries, microfractures, and fractures. The shallow-level gabbro and the limited suite of deeper gabbro show that incipient flow occurred at amphibolite facies (average temperature $=$ $720^{\circ} \mathrm{C}$ ) conditions and is manifest by amphibole veins that display no preferred orientation (Manning et al., 1996; Coogan et al., 2002a) and replacement of pyroxene by amphibole-dominated assemblages (Früh-Green et al., 1996; Gillis, 1995; Kirchner and Gillis, 2012). Whole-rock samples unaffected by a lower temperature stage of brittle deformation (see below) are depleted in $\delta^{18} \mathrm{O}$ relative to fresh values (Agrinier et al., 1995; Lecuyer and Reynard, 1996) and show minor enrichment in ${ }^{87} \mathrm{Sr} /{ }^{86} \mathrm{Sr}$ (data for shallow-level gabbro only) (Lécuyer and Gruau, 1996; Kirchner and Gillis, 2012). Calculated fluid/ rock ratios using both isotopic systems range from 0.1 to 1 (Lécuyer and Gruau, 1996; Lecuyer and Reynard, 1996; Kirchner and Gillis, 2012). The rate of cooling of the shallow-level gabbro is rapid $\left(1,000^{\circ}\right.$ to $60,000^{\circ} \mathrm{C} / \mathrm{m}$.y.) and comparable to the upper gabbro section in the Oman ophiolite (Coogan et al., 2007; Faak et al., 2011).

When the shallow-level gabbro exposed along the intraridge rift cooled to $\sim 450^{\circ} \mathrm{C}$, it became influenced by the effects of Cocos-Nazca rifting, creating a dense array of east-west tensile fractures filled with greenschist to zeolite facies assemblages and local cataclasis cemented with the same assemblage (FrühGreen et al., 1996; Manning and MacLeod, 1996). The consequences of Cocos-Nazca rifting on deeper gabbro have not yet been constrained.

Mantle peridotite is exposed in the vicinity of ODP Site 895, southeast of Site 894 (Fig. F5). Clinopyroxene-poor harzburgite, at the most depleted end of the range for abyssal peridotite, is interpreted to be the residue of melting of a normal (N)-type MORB source (Natland and Dick, 1996). The association of dunite-troctolite-olivine gabbro with depleted harzburgite records the interaction of migrating melt with depleted harzburgite wall rock in the shallowest mantle (Natland and Dick, 1996; Arai and Matsukage, 1996; Arai et al., 1997). The geometry of these associations suggests that at least some melt trans- port was fracture-controlled. Significant modal layering in peridotite-hosted gabbroic rocks, a feature of the Oman mantle transition zone (Korenga and Kelemen, 1997), was not observed.

\section{Expedition objectives}

The principal objective for drilling at the Hess Deep Rift was to test competing hypotheses of magmatic accretion and hydrothermal processes in the lower ocean crust formed at the fast-spreading EPR. These hypotheses make predictions that can only be tested with drill cores, including the presence or absence of systematic variations with depth in mineral and bulk rock compositions, presence or absence of modally layered gabbro, variation of strain/deformation, and the extent and nature of hydrothermal alteration and deformation (Fig. F3). Specific scientific questions that address these predictions are outlined below.

\section{How is melt transported from the mantle through the lower crust?}

Melts erupting at mid-ocean ridges are rarely saturated in all four mantle phases at plausible segregation depths (O'Hara, 1968; Stolper and Walker, 1980). The upper mantle and crustal processes responsible for the evolution of mantle primary melts into primitive MORB are the subject of a great many studies in the geochemical literature (e.g., Kelemen et al., 1997). Melts are transported and aggregated by porous flow at both mantle and crustal levels; the latter process may be identified on the basis of textural and chemical evidence. The different mechanisms of igneous differentiation (e.g., fractional crystallization, equilibrium crystallization, assimilation, and porous reactive flow) strongly influence the chemical evolution of residual liquids and host cumulates. Melt transport through the lower crust is an important boundary condition of the crustal accretion models. Is melt transported largely by porous flow through the lower crust, or is it transported in dike-like brittle fractures (Kelemen and Aharonov, 1998)? Previous studies at Hess Deep suggest that the liquid line of descent of lower crustal magmas may significantly differ from established models of MORB petrogenesis (Coogan et al., 2002a). This involves a much earlier and much more important role for orthopyroxene, such that primitive orthopyroxene is found in deeper level gabbro and in greater abundance in the Hess Deep shallow-level gabbro (Site 894) than in either the Oman ophiolite or slowspreading ridges (i.e., Legs 118 and 176 and Expedition 304/305). Mineral and bulk chemical data for 
the core will provide tests for these and potentially other mechanisms of igneous differentiation and melt transport in the base of the ocean crust.

\section{What is the origin and significance of layering?}

Modally and compositionally layered gabbroic rock is common in the lower crustal sections of ophiolite (e.g., Anonymous, 1972). A layered lower crust is therefore one of the key and nearly ubiquitous features of all models of fast-spreading lower crust. However, pronounced modal layering of the sort observed in major ophiolites has rarely been observed or sampled on the ocean floor. This may be due to the lack of drilling into the deeper levels of fastspreading plutonic crust; commonly used sampling and observation methods are not ideal to detect such layering readily, the right areas have not been sampled, or pronounced modal layering is absent. If ophiolites indeed represent sections of normal midocean ridge crust, we expected to drill significant thicknesses of layered igneous rock during this expedition. The nature and extent of layering is likely to have a strong bearing on the applicability of ophiolite-based accretionary models for the formation of the lower ocean crust.

\section{How, and how fast, is heat extracted from the lower plutonic crust?}

It is generally accepted that hydrothermal fluids initially penetrate all levels of the plutonic crust along microfracture networks at high temperatures, with fractures sealing at $600^{\circ}-800^{\circ} \mathrm{C}$ (Alt et al., 2010; Manning et al., 1996; Coogan et al., 2002a). Initiation of incipient cracking in the upper gabbro at Hess Deep overlaps the solidus temperatures of the most evolved lithologies, as recorded by magmatic amphibole $\left(850^{\circ}-925^{\circ} \mathrm{C}\right)$ (Gillis et al., 2003) and zircon $\left(690^{\circ}-790^{\circ} \mathrm{C}\right)($ Coogan and Hinton, 2006) using plagioclase-amphibole and Ti-in-zircon thermometry, respectively. Whether this is the case in the lower plutonic crust, where more primitive lithologies dominate, is not known. Penetration of fluids at high enough temperatures could promote hydrous partial melting (Koepke et al., 2007) as observed in slow-spreading and ophiolitic environments. Whether and at what depths this process occurs in fast-spreading lower crust is not known. Cooling rates for upper gabbro sections from fast-spreading crust and equivalent sections from the Oman ophiolite are rapid $\left(1,000^{\circ}-60,000^{\circ} \mathrm{C} / \mathrm{m}\right.$.y.) (Coogan et al., 2002b, 2007), indicative of significant convective cooling. Slower cooling rates in deeper level gabbro suggest that heat flow was largely conductive (Coogan et al., 2007); cooling rates for lower gabbro sections from fast-spreading crust are not known. Key questions that will be addressed include

- What is the rate of cooling with depth?

- Is hydrothermal flow along microfracture networks an effective mechanism to cool the lower crust?

- When is hydrothermal cooling initiated?

- Does fluid penetration occur at high enough temperatures to induce hydrous partial melting?

- Does the lower crust cool largely by conductive or convective heat transport? This question is intimately linked to the overall crustal accretion models, as the gabbro glacier model is conductively cooled, while the sheeted sill model requires convective cooling of the lower crust.

\section{What are the fluid and geochemical fluxes in the East Pacific Rise lower plutonic crust?}

Our understanding of the extent of fluid flow and reaction in the oceanic lower crust is presently very limited. Thermal models developed to test the crustal accretion models predict that advective cooling of the lower plutonic crust at or very close to the EPR would lead to a progressive decrease in the fluid flux and attendant fluid-rock interaction with depth, whereas more gradational conductive cooling over a broader timeframe would likely lead to lower fluid fluxes and more limited fluid-rock interaction (Fig. F3). Bulk rock Sr isotope data have constrained the time-integrated fluid fluxes for the upper crust (Bickle and Teagle, 1992; Gillis et al., 2005; Teagle et al., 2003; Kirchner and Gillis, 2012), and application of this approach will allow us to constrain fluid fluxes in the lower crust. Thermodynamic modeling predicts that high-temperature fluid flow and reaction would leave little macroscopic evidence (McCollum and Shock, 1998), which is supported by $\delta^{18} \mathrm{O}$ data for petrologically fresh samples (Alt and Bach, 2006; Gao et al., 2006). Thus, it will be critical to combine petrological and geochemical data to assess the extent of fluid-rock interaction in the lowermost plutonic crust. Key questions that will be addressed include

- How does the total extent of alteration vary with depth?

- How does fluid flux vary with depth?

- What is the extent of chemical exchange between the lower crust and seawater?

- At what temperature is fluid-rock interaction initiated?

- What is the role of magmatic fluids? 


\section{Drilling strategy}

The highest priority for drilling at Hess Deep was to sample one or more 100 to $\geq 250 \mathrm{~m}$ long sections of primitive gabbroic rock. The Expedition 345 Scientific Prospectus (Gillis et al., 2012) identified three primary drill sites (proposed Sites HD-01B-HD-03B), with the intention that if coring was proceeding well in the first or second sites, it would be continued as long as possible in order to capitalize on good drilling conditions and obtain the longest possible continuous sample. Site survey data in conjunction with on-bottom observations collected during the expedition were used to plan specific hole locations in the vicinity of proposed Sites HD-01B-HD-03B.

We anticipated that drilling, coring, and logging operations in the Hess Deep Rift could be quite challenging. Thus, the operations team prepared a range of potential operational approaches that could be applied to address challenges that included water depths in excess of $4500 \mathrm{~m}$, very thin sediment cover, initiating/maintaining a hole through the basement contact, and coring deeply through potentially unstable basement. These approaches included the possible deployment of a standard reentry cone, deployment of a free-fall funnel (FFF) or "nested" FFFs, bare rock hole without installation of a seafloor structure, and bare rock installation of a reentry cone with a short entry pup. In addition, the experiences of previous hard rock drilling expeditions were reviewed for best practices (see "Operations plan" in the Expedition 345 Scientific Prospectus [Gillis et al., 2012] for more details).

The initial focus for drilling during Expedition 345 was a flat-lying east-west-trending sedimented bench at $\sim 4850$ mbsl along the southern slope between the intrarift ridge and Hess Deep in an area previously shown to be dominated by primitive gabbro (Fig. F7). During the early stages of the expedition, permission was granted by the Environmental Protection and Safety Panel to expand the initial approved area of operations to the north of the bench to maximize drilling options along the southern slope of the intrarift ridge.

\section{Site summary}

Site U1415 is located along the southern slope of the intrarift ridge between 4675 and 4850 mbsl (Fig. F6). A series of 16 holes were drilled at Site U1415, two $\sim 110$ meters below seafloor (mbsf) reentry holes (U1415J and U1415P), six single-bit holes (U1415E and U1415G-U1415I, U1415O), two failed reentry holes (U1415K and U1415M), and six holes in which jet-in tests were conducted to assess sediment thick- ness (Holes U1415A-U1415D, U1415F, and U1415L) (Figs. F8, F9; Table T1).

Site U1415 is centered on a $\sim 200 \mathrm{~m}$ wide, flat-lying east-west-trending bench at $4850 \mathrm{mbsl}$ that is covered with approximately $<10-30 \mathrm{~m}$ of largely gabbroic rubble overlain by a few meters of pelagic sediment mixed with lithic debris. Holes U1415EU1415J and Holes U1415O and U1415P are in an area where primitive $(\mathrm{Mg} \#=75-85)$ gabbroic rocks were recovered from above and below the bench during the JC21 site survey (C.J. MacLeod, pers. comm., 2009) (see distribution of olivine gabbros in Fig. F7; see also Fig. F8). Holes U1415K-U1315N are situated along a $\sim 100 \mathrm{~m}$ wide, flat-lying shoulder at $\sim 4675 \mathrm{mbsl}, \sim 160 \mathrm{~m}$ shallower than the bench (Fig. F8), where slightly more evolved gabbroic rocks were recovered during the JC21 site survey (Fig. F7).

Specific hole locations were selected in the general area of the proposed drill sites (HD-01B to HD-03B) using a combination of geomorphology, seafloor observations, and shallow acoustic subbottom profiling data. Early in the expedition, exploratory visual and seismic surveys combined with jet-in tests showed that the sediment thickness on the bench was at most a few meters. This meant deployment of a standard reentry system was not feasible; thus an approach using a hard rock FFF reentry system with casing was implemented (see "Operations summary"). Our early drilling results lead us to reevaluate the origin of the seafloor morphology observed in the microbathymetry of the bench area. Smallscale topography was reinterpreted to be related to mass wasting above and within the bench rather than extensional faulting along the bench, as previously thought. Thus, the strategy for placing the drill holes was modified slightly to focus on structural promontories separating areas where slumping may have dominated.

Drilling at Site U1415 also revealed that, at least locally, the bench was not a coherent fault block as originally proposed (Ferrini et al., 2013). Near-bottom $3.5 \mathrm{kHz}$ acoustic subbottom profiling data suggest the presence of several fault or slump blocks with complicated structural relationships both along and across strike. Variations in inclination of stable, high unblocking temperature magnetic components indicated that at least two blocks had been sampled in each reentry hole, providing evidence of relative displacements of individual, internally coherent units. The scale of these blocks can be assessed in the two deepest holes, U1415J and U1415P (Figs. F10, F11). In Hole U1415J, consistency in the dip of magmatic foliation and magnetic inclinations identify two discrete blocks with vertical thicknesses of 29 and $\geq 50 \mathrm{~m}$. In Hole U1415P, rock type and magnetic 
inclinations suggest two blocks of 65 and $\geq 42 \mathrm{~m}$ thickness.

The evidence of local mass wasting observed at Site U1415 and the prediction that mass wasting is a regional phenomenon (Ferrini et al., 2013) call into question the sensibility of assigning a stratigraphic position for any samples recovered along the southern slope of the intrarift ridge. The exception is the crest of the intrarift ridge. Here, the stratigraphic position of the gabbroic rocks is well constrained as being close to the sheeted dike-gabbro transition. This conclusion is based on the presence of dolerites with EPR compositions interpreted as sheeted dikes along the northern slope of the intrarift ridge (Fig. F6) and cooling rates comparable to the uppermost gabbro along the Northern Escarpment of the Hess Deep Rift (Coogan et al., 2007). Thus, we do not present our expedition results in a regional depth context and strongly caution against the use of depth profiles for any samples recovered from the southern slope of the intrarift ridge (cf. Hékinian et al., 1993; Lissenberg et al., 2013).

A precise stratigraphic context for Site U1415 is not required to address most of the specific scientific objectives of Expedition 345. It is important, however, to comment on what can be constrained concerning the original depth of the Site U1415 primitive gabbro in the EPR plutonic crust. No primitive gabbro occurs within $1 \mathrm{~km}$ of the base of the sheeted dike complex along the northern escarpment of Hess Deep Rift (Hanna, 2004; Kirchner and Gillis, 2012; Natland and Dick, 1996). Primitive olivine gabbro along the southern slope of the intrarift ridge first crops out at 3800-4000 mbsl, within $\sim 2 \mathrm{~km}$ of the inferred sheeted dike complex (Lissenberg et al., 2013) (Fig. F6). As these samples were recovered along a very steep slope inferred to be the head wall of a large mass wasting feature, we suggest they are in place in the context of the intrarift ridge block itself (unlike samples recovered at greater depths). Thus, we conclude that the primitive lithologies at Site U1415 formed at a minimum of $2 \mathrm{~km}$ beneath the sheeted dike complex, in the lower half to onethird of the $3.8-4.8 \mathrm{~km}$ thick plutonic sequence.

\section{Magmatic accretion of fast-spreading East Pacific Rise lower crust}

\section{Major units recovered during drilling}

Olivine gabbro and troctolite are the major plutonic rock types encountered at Site U1415, with minor gabbro, clinopyroxene oikocryst-bearing troctolite, clinopyroxene oikocryst-bearing gabbro, and gabbronorite (Fig. F12). The primary science results were obtained from core recovered from reentry Holes
U1415J and U1415P (located $110 \mathrm{~m}$ apart) and the single-bit Hole U1415I (located $10 \mathrm{~m}$ south of Hole U1415J) (Figs. F8, F9). Paleomagnetic analysis demonstrates that rock types sampled in these holes carry stable magnetizations that unblock close to the magnetite Curie temperature; these are considered to represent primary thermoremanent magnetizations acquired during crustal accretion. Significant and abrupt downhole changes in the inclination of these magnetization components (Fig. F13) cannot be explained by EPR- or Hess Deep-related faulting. Instead, they indicate that Holes U1415J and U1415P penetrated discrete, 30 to $\geq 65 \mathrm{~m}$ sized blocks displaced during mass wasting. The discontinuities in magnetic inclination downhole in each hole correspond to the major changes in lithology and dip of magmatic fabrics (foliation, and/or layering). Hence, it is possible to divide the recovered rocks into coherent units (Figs. F10, F11, F14, F15, F16) based on a combination of rock type, structural, and paleomagnetic inclination data, with boundaries between units representing discontinuities between adjacent displaced blocks.

Layered gabbroic rock is encountered beneath the rubble unit in each hole, but varies in characteristics between holes. We define a Layered Gabbro Series in Hole U1415I (Unit II) and an Oikocryst-Bearing Layered Gabbro Series in Hole U1415J (Unit II) (Figs. F10, F16) that are composed of olivine gabbronorite, olivine-orthopyroxene gabbro, and clinopyroxene oikocryst-bearing troctolite. These units have moderate to strong magmatic foliation subparallel to the igneous layering. The units are host to spectacular modal and grain size layering, with boundaries between layers defined by changes in mineral modes and/or grain size, and are primarily sutured such that individual mineral grains span the boundary (Fig. F17). The Layered Gabbro Series in Hole U1415I and the Oikocryst-Bearing Layered Gabbro Series in Hole U1415J (Figs. F10, F11, F16) are considered correlative (Fig. F15) because of similarities in their depth of recovery, lithology, and dip of magmatic layering and foliation and their very close proximity (Fig. F9). This combined layered series has a subsurface horizontal extent of at least $10 \mathrm{~m}$ and a vertical thickness of $\sim 30 \mathrm{~m}$.

The Multitextured Layered Gabbro Series in Hole U1415P (Unit II) is composed of a $\sim 52 \mathrm{~m}$ thick sequence of olivine gabbro and orthopyroxene-bearing olivine gabbro with considerable banding, skeletal olivine textures, and occasional noritic bands (Fig. F11). This heterogeneous series is significantly different from the layered series in Holes U1415I and U1415J and reveals an extraordinary variety of textures that include variations in grain size, crystal 
morphology, and mineral fabrics. The series consists of a sequence of interfingered intervals that range from homogeneously textured primitive orthopyroxene-bearing olivine gabbro to dramatically banded or layered olivine gabbro with moderate to strong magmatic foliation. Banding can be divided into two broad categories: the more common, steeply dipping, asymmetric and sometimes diffuse leucocratic banding and less common, more regular, gently dipping grain size and modal layering.

Finally, a Troctolite Series was sampled at the base of Holes U1415J (Unit III) and U1415P (Unit III) (Figs. F10, F11, F15). These rocks are lithologically similar between holes, with melanocratic to leucocratic troctolite that commonly hosts weak olivine-plagioclase foliation in Hole U1415J and moderate to strong foliation in Hole U1415P, and contains little to no modal layering (Fig. F18). Paleomagnetic data from both holes indicate that the Troctolite Series carries a stable remanence with moderate negative inclinations but with potential for some relative rotation of the sampled sections between holes (Figs. F13, F15).

\section{Gabbroic rock}

Olivine gabbro is the dominant rock type recovered at Site U1415, occurring in both the layered series in Holes U1415I, U1415J, and U1415P and the Troctolite Series in Hole U1415P (Figs. F10, F11) (see below). Olivine gabbro is dominantly medium grained with equigranular granular to granular poikilitic textures and consists of olivine (5\%-30\%), plagioclase (45\%-70\%), and clinopyroxene (5\%-45\%), with trace amounts of orthopyroxene and oxides. Olivine is subhedral to euhedral with an equant to amoeboid to skeletal habit, tabular plagioclase is euhedral to subhedral, and clinopyroxene is anhedral, dominantly subequant, and often poikilitic. In Hole U1415P, multitextured olivine gabbro displays complex variation in modal proportions of minerals, grain size, and mineral habit.

An unexpected observation is the prevalence of orthopyroxene-bearing rock types, predominately orthopyroxene-bearing olivine gabbro and minor olivine-bearing gabbronorite (Figs. F10, F11). These medium- to coarse-grained, equigranular granular rocks consist of olivine $(10 \%-20 \%)$, plagioclase $(50 \%-70 \%)$, clinopyroxene $(15 \%-30 \%)$, orthopyroxene $(1 \%-4 \%)$, and trace amounts of oxide (Cr-spinel). Olivine is subhedral to anhedral with an equant to amoeboid to skeletal habit, plagioclase is euhedral to subhedral with a tabular habit, clinopyroxene is anhedral forming interstitial grains, and orthopyroxene is euhedral to anhedral forming subequant to equant prismatic or interstitial grains (Fig. F19). In some occurrences, orthopyroxene appears as an early phase, in which it is locally intergrown with olivine, followed by late-stage clinopyroxene (Fig. F20).

Troctolite is the second most abundant lithology, forming decimeter-scale intervals within the Layered Gabbro Series, Oikocryst-Bearing Layered Gabbro Series, and Multitextured Layered Gabbro Series and is the dominant lithology in the Troctolitic Series (see below). In Hole U1415J, troctolite consists of olivine $(20 \%-80 \%)$, plagioclase $(20 \%-5 \%)$, clinopyroxene $(<1 \%-10 \%)$, and trace amounts of oxide (possibly Cr-spinel). In Hole U1415P, troctolite has dominantly olivine $(20 \%-60 \%)$ and plagioclase $(40 \%-$ $80 \%)$ and only trace amounts of clinopyroxene $(<1 \%-4 \%)$ and oxide $(<1 \%$; Cr-spinel). In both holes, olivine is euhedral to subhedral with a subequant to amoeboid to skeletal habit, plagioclase is euhedral to anhedral with a tabular habit, and clinopyroxene is anhedral with an interstitial habit. Troctolite has an equigranular granular texture (Fig. F18).

Clinopyroxene oikocryst-bearing troctolite forms decimeter-scale intervals within the Layered Gabbro Series and Multitextured Layered Gabbro Series (Figs. F10, F16). Troctolite is medium grained, seriate poikilitic-granular rock with a strong grain size contrast between minerals in the troctolitic matrix and chadacrysts in large clinopyroxene oikocrysts (Fig. F21A). Troctolite consists of olivine $(10 \%-42 \%)$, plagioclase (45\%-70\%), and clinopyroxene oikocrysts (3\%$35 \%$ ), with trace amounts of oxide (possibly Cr-spinel) and orthopyroxene. Olivine is fine grained and subhedral to anhedral with an elongated, irregular amoeboid habit. Plagioclase is fine grained subhedral to euhedral with a tabular habit. Large clinopyroxene oikocrysts (up to $15 \mathrm{~mm}$ in diameter) are anhedral and poikilitic, with a distinctive population of irregularly shaped plagioclase chadacrysts (Fig. F22). Plagioclase chadacrysts are oriented in a random manner within the oikocrysts, in contrast to the surrounding foliated plagioclase fabric. Plagioclase chadacrysts are commonly deformed. Olivine is absent as a chadacryst phase.

Gabbro primarily occurs in centimeter-scale intervals in the Layered Gabbro Series and Multitextured Layered Gabbro Series (Figs. F10, F15) where is fine to medium grained and has an equigranular granular texture. The primary mineralogy of gabbro is dominated by plagioclase $(55 \%-75 \%)$ and clinopyroxene $(25 \%-45 \%)$, with trace amounts of olivine, orthopyroxene, and oxide. Plagioclase is euhedral to subhedral with a tabular habit, whereas clinopyroxene is anhedral with a subequant habit.

\section{Bulk chemistry of gabbroic rock}

Olivine gabbro and gabbro recovered in Holes U1415H-U1415J and U1415P have high Mg\# (79- 
87) and Ca\# (77-92), high Ni contents (130-570 ppm), low $\mathrm{TiO}_{2}$ contents (0.1-0.3 wt\%), and incompatible lithophile element contents (e.g., $\mathrm{Y}<11$ ppm). Five samples are distinguished by a significantly higher $\mathrm{Cr}$ content (1500-2500 ppm) compared to neighboring gabbro (36-825 ppm). Clinopyroxene oikocryst-bearing troctolite and gabbro from the Layered Gabbro Series are similar in composition to the olivine gabbro. Orthopyroxene-bearing olivine gabbro has primitive compositions similar to neighboring gabbro and olivine gabbro and is characterized by high Mg\# (80-85) and Ca\# (77-87), high Ni (174-460 ppm) and $\mathrm{Cr}(150-2560 \mathrm{ppm})$ contents, low $\mathrm{TiO}_{2}$ contents $(0.1-0.3 \mathrm{wt} \%)$, and trace element contents (e.g., $\mathrm{Y}<6 \mathrm{ppm}$ ).

Troctolite overlaps in composition with gabbro but has, on average, more primitive compositions with high Mg\# (81-89) and Ca\# (79-98), high Ni (260$1500 \mathrm{ppm})$ and $\mathrm{Cr}(365-1100 \mathrm{ppm})$ contents, low $\mathrm{TiO}_{2}$ contents $(<0.1 \mathrm{wt} \%)$, and incompatible lithophile element contents (e.g., Y $<3$ ppm). The most primitive troctolite sampled in Hole U1415P has compositions overlapping the field of impregnated mantle peridotite, including that from the Hess Deep Rift (Fig. F2; see also Fig. F1 in the "Geochemistry summary" chapter [Gillis et al., 2014]). However, these samples are low in $\mathrm{Ni}$ relative to their high

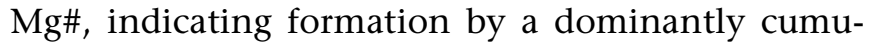
late process (see below).

The gabbroic rocks at Site U1415 are far more primitive than the shallow-level gabbro at the Hess Deep Rift and are similar in bulk composition to gabbro from the shallow gabbro from Pito Deep where fastspreading EPR crust is exposed (Perk et al., 2007). These primitive rock types fall within the range of primitive oceanic gabbro from fast-spreading crust, as illustrated in a $\mathrm{Mg \#}$ versus $\mathrm{Cr}$ content plot (Fig. F23). The Cr contents of these rocks likely reflect the crystallization of Cr-spinel from a Cr-rich primitive parent magma. For comparison with oceanic gabbro cores recovered from slow-spreading ocean crust, see the "Geochemistry summary" chapter (Gillis et al., 2014).

\section{Basaltic and hypabyssal rock}

Basalt and dolerite were largely recovered from the surficial rubble zone. The relationship between these rocks and the gabbroic units was only documented in the Troctolite Series in Hole U1415J where minor dikes are associated with zones of brittle deformation. The primary rock types in Hole U1415N are moderately to highly olivine-phyric basalt and dolerite. Compositions of these basalts are at the primitive, depleted end of the EPR trend. Basalts found within the cataclastic intervals are discussed below.

\section{Hydrothermal alteration of fast-spreading East Pacific Rise lower crust}

The metamorphic mineral assemblages in the rocks recovered at Site U1415 record the cooling of primitive gabbroic lithologies from magmatic $\left(>1000^{\circ} \mathrm{C}\right)$ conditions at the EPR to zeolite $\left(<200^{\circ} \mathrm{C}\right)$ facies conditions associated with Cocos-Nazca rifting and exposure onto the seafloor. The intensity of alteration varies with igneous lithology, in particular the modal abundance of olivine, grain size, and proximity to zones of brittle fracturing and cataclasis.

\section{Pervasive alteration}

The freshest rock types at Site U1415 are found in the Layered Gabbro Series of Hole U1415I, the Oikocryst-Bearing Layered Gabbro Series of Hole U1415J, and the Multitextured Layered Olivine Gabbro Series in Hole U1415P. The average alteration intensity in these units is $\sim 40 \%(<10 \%-90 \%)$. Olivine is the most altered primary mineral (average $=55 \%-65 \%$ ), followed by clinopyroxene and orthopyroxene (average $=30 \%$ ) and plagioclase (average $=10 \%-20 \%$ ). The Troctolite Series in Holes U1415J and U1415P are more pervasively altered than the gabbroic series, with Hole U1415J troctolite being more altered $(\sim 80 \%)$ than in Hole U1415P ( 65\%). This likely reflects the presence of brittle cataclastic zones in Hole U1415J (see below). Similar to the gabbroic series, olivine is the most altered primary mineral $(65 \%-$ $75 \%)$, followed by plagioclase $(\sim 60 \%)$ and clinopyroxene (35\%-40\%). In summary, away from zones of brittle deformation alteration intensity is largely controlled by the bulk composition of the rock such that the most olivine-rich lithologies display the most alteration.

The secondary mineral assemblages display some differences between the gabbroic lithologies in the Layered Gabbro Series, Multitextured Layered Olivine Gabbro Series, and Troctolitic Series (Fig. F24). These differences are primarily related to the relative abundance of the secondary phases replacing olivine and plagioclase. In all of the layered series, serpentine is slightly more abundant than talc, chlorite, and clay minerals. All assemblages have lesser amounts of amphibole, clay minerals, minor secondary oxides, and sulfides. In contrast to the layered series, olivine replacement in the Troctolitic Series is dominated by serpentine with lesser and varying proportions of chlorite and clay minerals and lesser talc, amphibole, minor secondary oxides, and sulfides. Similar to olivine, the relative abundance of the secondary minerals replacing plagioclase varies with rock type. The abundance of prehnite and chlorite are approximately equal in all of the layered series, whereas prehnite is the most abundant secondary phase in 
the troctolites. In both rock types, secondary plagioclase, amphibole, and/or clay minerals also replace plagioclase. Secondary mineral assemblages replacing the other primary phases are not lithologically controlled. In all lithologies, clinopyroxene and orthopyroxene are largely replaced by amphibole and lesser chlorite.

A characteristic feature of altered olivine-rich gabbroic rocks is a concentric zonal aggregate of tremolite and chlorite that develops as a reaction product between olivine and plagioclase in oceanic gabbroic rocks (e.g., Nozaka and Fryer, 2011). Such corona textures are variably developed in all of the olivinebearing gabbroic lithologies recovered at Site U1415 but the completion of the corona-forming reaction (i.e., absence of relict olivine inside a corona) appears most frequently in the Troctolitic Series in Hole U1415J.

\section{Brittle fracturing and vein formation}

Alteration veins represent a ubiquitous, although volumetrically insignificant, component of the rock types recovered at Site U1415. They reflect the later stages of cracking, fluid circulation, and fluid-rock reaction experienced by the gabbroic rock recovered. Vein density is low except in the zones of extensive cataclasis found in Hole U1415J. The orientation of alteration veins is globally random; they form a network with no preferred orientation that is consistent with hydraulic fracturing.

A variety of vein mineralogies are observed at Site U1415, including amphibole, epidote, chlorite, serpentine, prehnite, carbonates, zeolite, and clay minerals. A systematic hierarchy in crosscutting relationships between veins with different fillings is hard to establish. Where present, amphibole and epidote veins are early, and mutually crosscutting relationships are observed for chlorite and prehnite. Zeolite veins are always late, crosscutting all other assemblages.

\section{Significant new observations}

\section{Layering}

A layered lower crust is one of the key and nearly ubiquitous feature of all models for the formation of fast-spreading lower crust. Despite this, observations of modal and/or grain size layering in fast-spreading oceanic gabbro, indeed gabbro formed at all spreading rates, is rare and restricted to short intervals (e.g., Pito Deep [Perk et al., 2007], ODP Hole 735B [Dick, Natland, Miller, et al., 1999], and IODP Site U1309 [Blackman, Ildefonse, John, Ohara, Miller, MacLeod, and the Expedition 304/305 Scientists, 2006]). This lack of layering is in contrast to ophiolite in which layering is nearly ubiquitous in the deeper levels of plutonic sequences. Recovery of the wide range of layering observed in the Site U1415 gabbroic rock is therefore of great significance, both for confirmation of its presence in fast-spreading crust and for its variety.

Two types of layering are seen at Site U1415: (1) simple centimeter- to decimeter-scale layering defined by differences in modal mineralogy and, more rarely, in grain size and (2) asymmetric and sometimes diffuse leucocratic banding (Fig. F25). Regular layering is largely defined by variation in modal olivine, plagioclase, and to a lesser extent pyroxene; the layers have sharp planar boundaries on a $<1 \mathrm{~cm}$ scale (Fig. F25A, F25B). In Hole U1415J, some of the boundaries show grain size variation caused by the appearance of large $(2-5 \mathrm{~mm})$ pyroxene crystals and others by increases in olivine grain size from 1-2 to $>5 \mathrm{~mm}$. This type of layering is particularly well developed in intervals of olivine gabbro and gabbro in the Layered Gabbro Series in Hole U1415I and the OikocrystBearing Layered Gabbro Series in Hole U1415J. Weak to strong magmatic foliation is common in intervals with simple layering where its orientation is generally parallel to the layers.

Diffuse layering or banding, restricted to the olivine gabbro and gabbro intervals in the Multitextured Layered Gabbro Series in Hole U1415P, is defined by modal, grain size, and shape variations in plagioclase, olivine, orthopyroxene, and clinopyroxene and mainly manifests as variably distinct leucocratic and melanocratic bands (Fig. F25C). Magmatic foliation areas are poorly developed to absent in the Multitextured Layered Gabbro Series.

Layer boundaries are mainly sutured (Fig. F17) with minor gradation, implying that they developed at hypersolidus conditions. The simple layering observed in Holes U1415I and U1415J is reminiscent of that found in mafic layered intrusions (Parsons, 1986). The diffuse banding in Hole U1415P is different, with textures and modal layering suggestive of magma mixing.

\section{Orthopyroxene in primitive gabbroic rock}

The common occurrence of orthopyroxene in primitive gabbroic rock at Site U1415 was not expected. Orthopyroxene is a minor $(<5 \%)$ and, in some centimeter-scale domains, a major (up to $25 \%$ ) phase in olivine gabbro, gabbro, troctolite, and gabbronorite (Figs. F19, F20). These orthopyroxene-bearing rocks have $\mathrm{Mg \#}$ ranging from $\sim 79$ to 87 . Although gabbronorite is common and expected in evolved (average $\mathrm{Mg \#}=\sim 58$ ) shallow-level gabbro at the Hess Deep Rift (Gillis, Mével, Allan, et al., 1993; Natland and Dick, 1996; Coogan et al., 2002a), orthopyrox- 
ene has only once been observed in fast-spreading primitive gabbro (Coogan et al., 2002a).

The presence of orthopyroxene as a cumulate phase at Site U1415 is significant, as it is considered to be one of the last major minerals to crystallize from MORB-like tholeiitic liquids (e.g., Stolper and Walker, 1980; Grove and Bryan, 1983; Grove et al., 1992; Feig et al., 2006). One model suggests that melts crossing the crust/mantle boundary were either generated by shallow mantle melting, or reequilibrated with the shallow mantle as they were transported through it, and crystallized within the crust without first mixing with aggregated MORB melts in the crust (Coogan et al., 2002a). This model led Coogan et al. (2002a) to propose that some of the melt extracted from the mantle is fully aggregated within the mantle but reacts with the shallow mantle during melt extraction. Alternatively, phase relationships derived from experimental studies cited above may be different from those observed at Site U1415 because of differing conditions. This emphasizes the importance of postcruise research to address this.

\section{Olivine textures and their significance in characterizing strain}

Intrinsic to the layering observed at Site U1415 is the development of dendritic and/or skeletal olivine textures in the cumulate rocks (Fig. F21B). These types of textures have been shown to be indicative of magmatic undercooling (O'Driscoll, 2007; Donaldson, 1982). Importantly, the local presence of these olivine textures shows that deformation subsequent to crystallization of these grains was locally minimal, otherwise these delicate structures would be destroyed.

\section{Clinopyroxene oikocrysts}

The textures of clinopyroxene observed in gabbroic rocks at Site U1415 are remarkable for their complexity and diversity compared to previously sampled ocean crust. Textural habits range from equant granular clinopyroxene to centimeter-scale oikocrysts of poikilitic clinopyroxene. One particular clinopyroxene texture is so distinctive that, for the purposes of description, its host rock was named clinopyroxene oikocryst-bearing troctolite. Large poikilitic clinopyroxene oikocrysts commonly occur in a range of gabbroic lithologies recovered from elsewhere in the oceanic crust (e.g., Blackman, Ildefonse, John, Ohara, Miller, MacLeod, and the Expedition 305/305 Scientists, 2006; Cannat et al., 1995; Dick, Natland, Miller, et al., 1999; Gillis, Mével, Allan, et al., 1993; Melson and Thompson, 1970); the clinopyroxene oikocrysts in clinopyroxene oikocryst-bearing trocto- lite at Site U1415 (Fig. F21A) are different. Here, the clinopyroxene forms large, centimeter-scale, isolated oikocrysts contrasting strongly with a finer grained (millimeter scale) foliated troctolitic matrix. Plagioclase chadacrysts may be undeformed, bent with deformation twins and subgrains, or annealed; they may also be resorbed. No olivine chadacrysts were observed. These varying textures record a potentially complex hypersolidus deformation history of the crystal mush. We speculate that the origin of this distinctive clinopyroxene texture is related to melt migration and reaction within the lower oceanic crust. Similar lithologies have been well documented from particular horizons in tholeiitic layered intrusions in continental settings (Olmsted, 1979; Mathison, 1987), providing evidence for a commonality between some magmatic processes occurring at both layered intrusions and mid-ocean ridges, as originally proposed by Melson and Thompson (1970).

\section{Pervasive hydrothermal alteration}

Pervasive alteration in the gabbroic rock types recovered spanned amphibolite to subgreenschist facies conditions $\left(>700^{\circ}\right.$ to $<200^{\circ} \mathrm{C}$ ) (Fig. F26). Clear evidence for early high-temperature amphibolite facies is rare and is manifested by the rare occurrence of brown amphibole and green spinel associated with olivine replacement in Hole U1415J. Some of the secondary amphibole associated with pyroxene and plagioclase replacement may also record amphibolite facies, by analogy with gabbroic rock from elsewhere at Hess Deep, but must be confirmed by postcruise analyses. Incipient alteration in the majority of the recovered core occurred at lower amphibolite $\left(450^{\circ}-\right.$ $650^{\circ} \mathrm{C}$ ) facies based on corona textures and olivine alteration assemblages (e.g., Frost et al., 2008; Nozaka and Fryer, 2011). The predominant alteration occurred at greenschist $\left(<400^{\circ} \mathrm{C}\right)$ to subgreenschist $\left(<200^{\circ} \mathrm{C}\right)$ facies, as evidenced by serpentine, chlorite, and prehnite assemblages and zeolite and clay mineral assemblages, respectively.

Pervasive alteration in Site U1415 primitive gabbroic rock differs from the more evolved, shallow-level gabbro found at the crest of the intrarift ridge and Northern Escarpment at Hess Deep. On average, this shallow-level gabbro is fresher, particularly in comparison with troctolite, and the dominant alteration is amphibole after pyroxene and minor secondary plagioclase and amphibole and chlorite after igneous plagioclase (Früh-Green et al., 1996; Gillis, 1995; Kirchner and Gillis, 2012). As olivine is absent or of low modal abundance in the shallow gabbro, abundant serpentine and talc would not be expected. Moreover, the lack of prehnite and chlorite replacing 
plagioclase may also be related to olivine abundance, as prehnite and chlorite may be by-products of the serpentinization process described above. Another feature that is ubiquitous, though with variable abundance, in the shallow gabbro and rare at Site U1415 is amphibole filling microfractures and lining grain boundaries at amphibolite facies $\left(>700^{\circ} \mathrm{C}\right)$. An important question to address is whether incipient fracturing at amphibolite facies is rare in fast-spreading primitive gabbro or if mineral assemblages differ because of their more evolved bulk compositions (e.g., McCollom and Shock, 1998). A third possibility is that the observations at Site U1415 simply reflect local scale heterogeneity caused by, for example, proximity to a zone of focused fluid flow (Coogan et al., 2006).

\section{Evolution of cataclastic deformation, magmatism, and hydrothermal alteration}

Another significant result of Expedition 345 is the recovery of blocks hosting a record of cataclasis whose development was synchronous with basaltic dike intrusion. These samples come from a fault zone cutting the Troctolite Series of Hole U1415J, where the recovered core documents complex interactions between cataclastic faulting, fluid flow and alteration, and magmatism. Cataclasis is largely localized at two depth intervals in the Troctolite Series, where brittle fabrics range from dense-anastomosing fractures to well-developed breccias and cataclasite. Elsewhere in Holes U1415J and U1415P, only very thin (less than centimeter scale) zones of fracturing and cataclasis were recovered.

The zone of brittle deformation in Hole U1415J exhibits heterogeneous grain sizes and degree of alteration and reflects the variable intensity of cataclasis at the centimeter scale. Cataclastic fabrics are characterized by grain size reduction through microcracking and rotation of the primary igneous and metamorphic minerals. This microstructure is commonly cut by prehnite and minor chlorite veins that are in turn cut by another period of cataclastic deformation. Locally, prehnite and chlorite veins are deformed and crosscut by later prehnite and chlorite veins. These relations indicate a complex succession of vein formation and brittle deformation.

Intervals of core host evidence of localized dike intrusion synchronous with the development of fault rocks in Hole U1415J. This is based on the combined evidence from textures of several pieces of fractured dolerite, two of which have very fine grained margins adjacent to altered locally cataclastic gabbro. As an example, microstructural observations suggest that one dolerite was likely emplaced into cohesive gabbro cataclasite hosting variable intensity prehnite/chlorite alteration. Boundaries with the cataclasite are sharp, with a distinctive increase in grain size away from the contact. Similar to elsewhere in the zones of fracture and cataclasis, the dolerite, contact zone, and cataclastic gabbro are cut by epidote and chlorite veins that were deformed by later brittle deformation. These relationships suggest the following sequence of events:

1. Localized fracture, cataclasis, and fluid flow associated with faulting and low-temperature $\left(<400^{\circ} \mathrm{C}\right)$ vein formation;

2. Vein intrusion;

3. Further cataclasis;

4. Dolerite dike emplacement; and

5. Another phase of brittle fracture.

A critical unresolved question is the timing of faulting and dike injection, as this would determine whether these processes are associated with the EPR or Cocos-Nazca Ridge. Results from Expedition 345 cannot readily resolve this issue. However, comparison with Hole 894G core may provide some constraints, as localized zones of cataclasite and vein networks with similar textures and alteration mineral assemblages to those found in Holes U1415J and U1415P were recovered. Magnetic and Formation MicroScanner data from Hole 894G indicate that veins and fractures show a strong preferred east-west strike and steep south-facing dips (MacLeod et al., 1996b). Because the EPR strikes north-south at this latitude, the veins' east-west orientations suggest formation by a mechanism unrelated to fracturing in an EPR hydrothermal system. This suggests that brittle deformation and alteration may be associated with Cocos-Nazca rifting.

\section{Multicomponent remanences in young lower oceanic crust}

Paleomagnetic demagnetization experiments conducted during Expedition 345 on discrete samples of both gabbroic and troctolitic rocks yielded stable magnetization directions with a variety of remanence structures. In all samples, components that unblock close to the magnetite Curie temperature (Fig. F27) are considered to represent primary thermoremanent magnetizations acquired during crustal accretion. These components have been used to assess the structural continuity and size of blocks sampled during the expedition. In addition to these high unblocking temperature components, thermal demagnetization experiments also identified more complex remanences in several core pieces sampled in Hole U1415J. These show nearly antipodal components of magnetization in individual samples that unblock over different temperature ranges (Fig. F27). This indicates that magnetizations were acquired 
across a protracted time interval spanning at least two geomagnetic polarity chrons. Such remanences have only been observed rarely in oceanic crust (MARK area and Atlantis Massif; Meurer and Gee, 2002; Morris et al., 2009), and may potentially result from slow cooling across reversal boundaries, thermal resetting by intrusive events, or phases of alteration resulting in thermoviscous remanence acquisition. Postcruise research aimed at understanding the origin of these multicomponent remanences may therefore provide constraints on temperatures at reversal boundaries or the timing of alteration.

\section{Preliminary scientific assessment}

Expedition 345 to Hess Deep Rift was remarkably successful, especially given the challenging operational conditions, which imposed less depth penetration and recovery than desired. Drilling into essentially rubble-covered fractured rock at water depths exceeding $4800 \mathrm{~m}$ meant that our operational objective of recovering one or more 100-250 $\mathrm{m}$ sections was only marginally achieved. Instead, one single-bit $35 \mathrm{~m}$ hole and two shallowly cased reentry $110 \mathrm{~m}$ holes with $14 \%-30 \%$ recovery were drilled. This is a remarkable achievement on the part of the operations team.

Expedition 345 achieved its primary scientific goal of recovering the first drilled sections of primitive gabbroic rock formed at a fast-spreading ridge. Drilling at Site U1415 provided the first confirmation of predictions that fast-spreading lower oceanic crust is layered. It also revealed a diversity of layering whose characteristics have similarities and differences to both layered sequences in ophiolites and layered mafic intrusions. Moreover, the core revealed significant unexpected mineralogical and textural diversity, some of which has been rarely observed in the lower oceanic crust elsewhere or in ophiolites. The core from Expedition 345 will be a reference section, for now the only reference section, for fast-spreading primitive lower ocean crust, which covers about half the Earth's surface. In this way, we surpassed our scientific expectations, making Expedition 345 a milestone for ocean crustal research.

Expedition 345 was designed to address the following objectives:

- What is the origin and significance of layering?

- How is melt transported from the mantle through the lower crust?

- How, and how fast, is heat extracted from the lower plutonic crust?
- What are the fluid and geochemical fluxes in the EPR lower plutonic crust?

The primitive gabbroic core recovered at Site U1415 makes it possible to address all of these scientific objectives, as well as some unanticipated objectives, such as

- Determining the origin of orthopyroxene in primitive lower ocean crust gabbros,

- Determining how plate separation is accommodated in the crust given the evidence against high-strain flow in a partially molten or subsolidus state,

- Reconstructing parental/primary MORB melt compositions using recovered olivine-phyric basalts in Hole U1415N,

- Distinguishing an EPR versus Cocos-Nazca Ridge source for basaltic dikes that intrude the gabbroic lithologies, and

- Evaluating the fluid flux and timing of localized zones of brittle fracturing and cataclasis.

These scientific objectives will primarily be addressed using core from the two reentry holes and one $35 \mathrm{~m}$ deep single-bit hole at Site U1415. The relationship of each of these objectives to core is briefly commented on below.

\section{What is the origin and significance of layering?}

Modally layered lower crustal gabbro has been central to our models for the ocean crust since the socalled "layer cake" model of the ocean crust was first developed (Anonymous, 1972). And yet to date, evidence for modally layered crust from drill core or samples recovered by other means has been sparse, comprising a single discrete sample and a small number of short drilled intervals (Perk et al., 2007; Dick, Natland, Miller, et al., 1999; Blackman, Ildefonse, John, Ohara, Miller, MacLeod, and the Expedition 305/305 Scientists, 2006). That is why recovery of abundant modally layered gabbro from the lower ocean crust, in particular that formed at a fastspreading ridge, is a tremendous achievement. Finally, we have unequivocal confirmation of a longstanding paradigm.

The layered series recovered in all holes display a remarkable variety, from simple modal layering to irregular and diffuse banding. Similarly, the recovered rocks display a spectacular variation in the development of the magmatic foliation. These differing types of magmatic foliation, magmatic layering, and their margins record complex histories of crystallization, melt migration, intrusion and mixing of melts, and deformation, to name a few of the contributing processes. 


\section{How is melt transported from the mantle through the lower crust?}

Many aspects of the recovered primitive gabbro were unexpected and call into question our understanding of MORB crystallization at fast-spreading ridges. The modal mineralogy of the Site U1415 core, in particular the abundance of orthopyroxene, demonstrates that crystallization of MORB at fast-spreading ridges may not proceed as expected. The mineral assemblages' growth and deformation textures show a remarkable complexity that implies that no single process can explain the crystallization of these primitive rocks. The types of processes that may be operative include simple cumulus crystallization, disequilibrium crystallization caused by undercooling of a melt, crystallization during melt extraction and compaction, and migration of melt either pervasively or in channels. Imposed on these are magmatic foliations ranging from weak to strong.

\section{How, and how fast, is heat extracted from the lower plutonic crust? What are the fluid and geochemical fluxes in the East Pacific Rise lower plutonic crust?}

These questions are combined here as they can be addressed primarily with postcruise research. The metamorphic assemblages and their relative age relationship in the Site U1415 core already provide some insight into the evolution of fluid-rock interaction. Some of this history is particular to the tectonic setting of Hess Deep, but much of the alteration is thought to be related to lower crustal cooling prior to tectonic disruption. Similar to primitive gabbro from slow-spreading ridges, primitive bulk compositions and the abundance of olivine lead to very different alteration histories, and it is expected that postcruise research will document the extent and nature of the resultant chemical exchange.

\section{Operations summary}

Expedition 345 occupied 16 holes in water depths ranging from 4675 to $4853 \mathrm{~m}$. Seven holes were cored by rotary core barrel, recovering $55.2 \mathrm{~m}$ of gabbroic rock. An additional $19.8 \mathrm{~m}$ of core was recovered during hole-cleaning operations ("ghost cores") (Table T1).

Two rotary core barrel holes were cored to $>100 \mathrm{mbsf}$ (111.8 mbsf in Hole U1415J and 107.9 mbsf in Hole $\mathrm{U} 1415 \mathrm{P})$. The other five rotary core barrel holes were cored to total depths ranging between 12.9 and 37.0 mbsf. The remaining holes occupied during Expedition 345 consisted of six jet-in tests and three failed attempts to establish reentry capability.

\section{References}

Agrinier, P., Hékinian, R., Bideau, D., and Javoy, M., 1995. $\mathrm{O}$ and $\mathrm{H}$ stable isotope compositions of oceanic crust and upper mantle rocks exposed in the Hess Deep near the Galapagos triple junction. Earth Planet. Sci. Lett., 136(3-4):183-196. doi:10.1016/0012-821X(95)00159-A

Alt, J.C., and Bach, W., 2006. Oxygen isotope composition of a section of lower oceanic crust, ODP Hole 735B. Geochem., Geophys., Geosyst., 7(12):Q12008. doi:10.1029/ 2006GC001385

Alt, J.C., Laverne, C., Coggon, R.M., Teagle, D.A.H., Banerjee, N.R., Morgan, S., Smith-Duque, C.E., Harris, M., and Galli, L., 2010. Subsurface structure of a submarine hydrothermal system in ocean crust formed at the East Pacific Rise, ODP/IODP Site 1256. Geochem., Geophys., Geosyst., 11(10):Q10010. doi:10.1029/2010GC003144

Anonymous, 1972. Penrose field conference on ophiolites. Geotimes, 17:24-25.

Arai, S., and Matsukage, K., 1996. Petrology of gabbro-troctolite-peridotite complex from Hess Deep, equatorial Pacific: implications for mantle-melt interaction within the oceanic lithosphere. In Mével, C., Gillis, K.M., Allan, J.F., and Meyer, P.S. (Eds.), Proc. ODP, Sci. Results, 147: College Station, TX (Ocean Drilling Program), 135-155. doi:10.2973/odp.proc.sr.147.008.1996

Arai, S., Matsukage, K., Isobe, E., and Vysotskiy, S., 1997. Concentration of incompatible elements in oceanic mantle: effect of melt/wall interaction in stagnant or failed melt conduits within peridotite. Geochim. Cosmochim. Acta, 61(3):671-675. doi:10.1016/S00167037(96)00389-4

Ballu, V., Hildebrand, J.A., and Canuteson, E.L., 1999. The density structure associated with oceanic crustal rifting at the Hess Deep: a seafloor and sea-surface gravity study. Earth Planet. Sci. Lett., 171(1):21-34. doi:10.1016/ S0012-821X(99)00132-6

Bédard, J.H., Sparks, R.S.J., Renner, R., Cheadle, M.J., and Hallworth, M.A., 1988. Peridotite sills and metasomatic gabbros in the eastern layered series of the Rhum complex. J. Geol. Soc. (London, U. K.), 145(2):207-224. doi:10.1144/gsjgs.145.2.0207

Berman, R.G., 1991. Thermometry using multiequilibria calculations: a new technique with petrologic applications. Can. Mineral., 29:833-855.

Bickle, M.J., and Teagle, D.A.H., 1992. Strontium alteration in the Troodos ophiolite: implications for fluid fluxes and geochemical transport in mid-ocean ridge hydrothermal systems. Earth Planet. Sci. Lett., 113(1-2):219237. doi:10.1016/0012-821X(92)90221-G

Blackman, D.K., Ildefonse, B., John, B.E., Ohara, Y., Miller, D.J., MacLeod, C.J., and the Expedition 304/305 Scientists, 2006. Proc IODP, 304/305: College Station, TX (Integrated Ocean Drilling Program Management International, Inc.). doi:10.2204/iodp.proc.304305.2006

Blum, N., 1991. Structure and composition of oceanic crust and upper mantle exposed in Hess Deep of the 
Galapagos microplate (equatorial east Pacific) [Ph.D.dissert.]. Univ. Karlsruhe, Germany.

Boudier, F., Nicolas, A., and Ildefonse, B., 1996. Magma chambers in the Oman ophiolite: fed from the top and the bottom. Earth Planet. Sci. Lett., 144(1-2):239-250. doi:10.1016/0012-821X(96)00167-7

Canales, J.P., Nedimovic, M.R., Kent, G.M., Carbotte, S.M., and Detrick, R.S., 2009. Seismic reflection images of a near-axis melt sill within the lower crust at the Juan de Fuca Ridge. Nature (London, U. K.), 460(7251):89-93. doi:10.1038/nature08095

Cannat, M., Karson, J.A., Miller, D.J., et al., 1995. Proc. ODP, Init. Repts., 153: College Station, TX (Ocean Drilling Program). doi:10.2973/odp.proc.ir.153.1995

Cannat, M., Mével, C., Maia, M., Deplus, C., Durand, C., Gente, P., Agrinier, P., Belarouchi, A., Dubuisson, G., Humler, E., and Reynolds, J., 1995. Thin crust, ultramafic exposures, and rugged faulting patterns at the Mid-Atlantic Ridge $\left(22^{\circ}-24^{\circ} \mathrm{N}\right)$. Geology, 23(1):49-52. doi:10.1130/0091-

7613(1995)023<0049:TCUEAR>2.3.CO;2

Chen, Y.J., 2001. Thermal effects of gabbro accretion from a deeper second melt lens at the fast spreading East Pacific Rise. J. Geophys. Res.: Solid Earth, 106(B5):85818588. doi:10.1029/2000JB900420

Cherkaoui, A.S.M., Wilcock, W.S.D., Dunn, R.A., and Toomey, D.R., 2003. A numerical model of hydrothermal cooling and crustal accretion at a fast spreading mid-ocean ridge. Geochem., Geophys., Geosyst., 4(9):8616. doi:10.1029/2001GC000215

Coogan, L.A., 2007. The lower oceanic crust. In Rudnick, R.L. (Ed.), Treatise on Geochemistry: The Crust (Vol. 3). Holland, H.D., and Turekian, K.K. (Series Eds.): New York (Elsevier), 1-45. doi:10.1016/B978-008043751-4/ 00230-3

Coogan, L.A., Gillis, K.M., MacLeod, C.J., Thompson, G.M., and Hékinian, R., 2002a. Petrology and geochemistry of the lower ocean crust formed at the East Pacific Rise and exposed at Hess Deep: a synthesis and new results. Geochem., Geophys., Geosyst., 3(11):8604. doi:10.1029/2001GC000230

Coogan, L.A., and Hinton, R.W., 2006. Do the trace element compositions of detrital zircons require Hadean continental crust? Geology, 34(8):633-636. doi:10.1130/ G22737.1

Coogan, L.A., Howard, K.A., Gillis, K.M., Bickle, M.J., Chapman, H., Boyce, A.J., Jenkin, G.R.T., and Wilson, R.N., 2006. Chemical and thermal constraints on focused fluid flow in the lower oceanic crust. Am. J. Sci., 306(6):389-427. doi:10.2475/06.2006.01

Coogan, L.A., Jenkin, G.R.T., and Wilson, R.N., 2007. Contrasting cooling rates in the lower oceanic crust at fastand slow-spreading ridges revealed by geospeedometry. J. Petrol., 48(11):2211-2231. doi:10.1093/petrology/ egm057

Coogan, L.A., Thompson, G., and MacLeod, C.J., 2002b. A textural and geochemical investigation of high level gabbros from the Oman ophiolite: implications for the role of the axial magma chamber at fast-spreading ridges. Lithos, 63(1-2):67-82. doi:10.1016/S00244937(02)00114-7

Crawford, W.C., and Webb, S.C., 2002. Variations in the distribution of magma in the lower crust and at the Moho beneath the East Pacific Rise at $9^{\circ}-10^{\circ}$ N. Earth Planet. Sci. Lett., 203(1):117-130. doi:10.1016/S0012821X(02)00831-2

Detrick, R.S., Buhl, P., Vera, E., Mutter, J., Orcutt, J., Madsen, J., and Brocher, T., 1987. Multi-channel seismic imaging of a crustal magma chamber along the East Pacific Rise. Nature (London, U. K.), 326(6108):35-41. doi:10.1038/326035a0

Dick, H.J.B., 1989. Abyssal peridotites, very slow spreading ridges and ocean ridge magmatism. In Saunders, A.D., and Norry, M.J. (Eds.), Magmatism in the Ocean Basins. Geol. Soc. Spec. Publ., 42(1):71-105. doi:10.1144/ GSL.SP.1989.042.01.06

Dick, H.J.B., Lin, J., and Schouten, H., 2003. An ultraslowspreading class of ocean ridge. Nature (London, U. K.), 426(6965):405-412. doi:10.1038/nature02128

Dick, H.J.B., Natland, J.H., and Ildefonse, B., 2006. Past and future impact of deep drilling in the oceanic crust and mantle. Oceanography, 19(4):72-80. doi:10.5670/ oceanog.2006.06

Dick, H.J.B., Natland, J.H., Miller, D.J., et al., 1999. Proc. ODP, Init. Repts., 176: College Station, TX (Ocean Drilling Program). doi:10.2973/odp.proc.ir.176.1999

Donaldson, C.H., 1982. Origin of some of the Rhum harrisite by segregation of intercumulus liquid. Mineral. Mag., 45(337):201-209. doi:10.1180/minmag.1982.045.337.23

Dunn, R.A., Toomey, D.R., and Solomon, S.C., 2000. Threedimensional seismic structure and physical properties of the crust and shallow mantle beneath the East Pacific Rise at $9^{\circ} 30^{\prime}$ N. J. Geophys. Res.: Solid Earth, 105(B10):23537-23556. doi:10.1029/2000JB900210

Durant, D.T., and Toomey, D.R., 2009. Evidence and implications of crustal magmatism on the flanks of the East Pacific Rise. Earth Planet. Sci. Lett., 287(1-2):130-136. doi:10.1016/j.epsl.2009.08.003

Evans, B.W., and Trommsdorff, V., 1974. On elongate olivine of metamorphic origin. Geology, 2(3):131-132. doi:10.1130/00917613(1974)2<131:OEOOMO>2.0.CO;2

Faak, K., Chakraborty, S., and Coogan, L.A., 2011. Evaluation of the variation in cooling rate with depth in the lower oceanic crust at fast-spreading ridges using a newly developed $\mathrm{Mg}$ in plagioclase geospeedometer [presented at the 2011 American Geophysical Union Fall Meeting, San Francisco, CA, 5-9 December 2011].(Abstract V13F-04) http://www.agu.org/meetings/fm11/waisfm11.html

Feig, S.T., Koepke, J., and Snow, J.E., 2006. Effect of water on tholeiitic basalt phase equilibria: an experimental study under oxidizing conditions. Contrib. Mineral. Petrol., 152(5):611-638. doi:10.1007/s00410-006-0123-2

Ferrini, V.L., Shillington, D.J., Gillis, K., MacLeod, C.J., Teagle, D.A.H., Morris, A., Cazenave, P.W., Hurst, S., Tominaga, M., and the JC21 Scientific Party, 2013. Evidence of mass failure in the Hess Deep Rift from multi-resolu- 
tional bathymetry data. Mar. Geol., 339:13-21. doi:10.1016/j.margeo.2013.03.006

Francheteau, J., Armijo, R., Cheminée, J.L., Hekinian, R., Lonsdale, P., and Blum, N., 1990. 1 Ma East Pacific Rise oceanic crust and uppermost mantle exposed by rifting in Hess Deep (equatorial Pacific Ocean). Earth Planet. Sci. Lett., 101:281(2-4)-295. doi:10.1016/0012821X(90)90160-Y

Frost, B.R., Beard, J.S., McCaig, A., and Condliffe, E., 2008. The formation of micro-rodingites from IODP Hole U1309D: key to understanding the process of serpentinization. J. Petrol., 49(9):1579-1588. doi:10.1093/ petrology/egn038

Früh-Green, G.L., Plas, A., and Dell'Angelo, L.N., 1996. Mineralogic and stable isotope record of polyphase alteration of upper crustal gabbros of the East Pacific Rise (Hess Deep, Site 894). In Mével, C., Gillis, K.M., Allan, J.F., and Meyer, P.S. (Eds.), Proc. ODP, Sci. Results, 147: College Station, TX (Ocean Drilling Program), 235254. doi:10.2973/odp.proc.sr.147.015.1996

Gao, Y., Hoefs, J., Przybilla, R., and Snow, J.E., 2006. A complete oxygen isotope profile through the lower oceanic crust, ODP Hole 735B. Chem. Geol., 233(3-4):217234. doi:10.1016/j.chemgeo.2006.03.005

Garmany, J., 1989. Accumulations of melt at the base of young oceanic crust. Nature (London, U. K.), 340(6235):628-632. doi:10.1038/340628a0

Gillis, K., Mével, C., Allan, J., et al., 1993. Proc. ODP, Init. Repts., 147: College Station, TX (Ocean Drilling Program). doi:10.2973/odp.proc.ir.147.1993

Gillis, K., Snow, J.E., and Klaus, A., 2012. Hess Deep plutonic crust: exploring the plutonic crust at a fast-spreading ridge: new drilling at Hess Deep. IODP Sci. Prosp., 345. doi:10.2204/iodp.sp.345.2012

Gillis, K.M., 1995. Controls on hydrothermal alteration in a section of fast-spreading oceanic crust. Earth Planet. Sci. Lett., 134(3-4):473-489. doi:10.1016/ 0012-821X(95)00137-2

Gillis, K.M., 2008. The roof of an axial magma chamber: a hornfelsic heat exchanger. Geology, 36(4):299-302. doi:10.1130/G24590A.1

Gillis, K.M., Coogan, L.A., and Chaussidon, M., 2003. Volatile element $(\mathrm{B}, \mathrm{Cl}, \mathrm{F})$ behaviour in the roof of an axial magma chamber from the East Pacific Rise. Earth Planet. Sci. Lett., 213(3-4):447-462. doi:10.1016/S0012821X(03)00346-7

Gillis, K.M., Coogan, L.A., and Pedersen, R., 2005. Strontium isotope constraints on fluid flow in the upper oceanic crust at the East Pacific Rise. Earth Planet. Sci. Lett., 232(1-2):83-94. doi:10.1016/j.epsl.2005.01.008

Gillis, K.M., Muehlenbachs, K., Stewart, M., Gleeson, T., and Karson, J., 2001. Fluid flow patterns in fast spreading East Pacific Rise crust exposed at Hess Deep. J. Geophys. Res.: Solid Earth, 106(B11):26311-26329. doi:10.1029/2000JB000038

Grove, T.L., and Bryan, W.B., 1983. Fractionation of pyroxene-phyric MORB at low pressure: an experimental study. Contrib. Mineral. Petrol., 84(4):293-309. doi:10.1007/BF01160283
Grove, T.L., Kinzler, R.J., and Bryan, W.B., 1992. Fractionation of mid-ocean ridge basalt (MORB). In Morgan, J.P., Blackman, D.K., and Sinton, J.M. (Eds.), Mantle Flow and Melt Generation at Mid-Ocean Ridges. Geophys. Monogr., 71:281-310. doi:10.1029/GM071p0281

Hanna, H.D., 2004. Geochemical variations in basaltic glasses from an incipient rift and upper level gabbros from Hess Deep, eastern equatorial Pacific [M.Sc. thesis]. Duke Univ., Durham.

Hékinian, R., Bideau, D., Francheteau, J., Cheminee, J.L., Henstock, T.J., Woods, A.W., and White, R.S., 1993. The accretion of oceanic crust by episodic sill intrusion. J. Geophys. Res.: Solid Earth, 98(B3):4143-4161. doi:10.1029/92JB02661

Henstock, T.J., Woods, A.W., and White, R.S., 1993. The accretion of oceanic crust by episodic sill intrusion. J. Geophys. Res.: Solid Earth, 98(B3):4143-4161. doi:10.1029/92JB02661

Hess, H.H., 1960. The AMSOC hole to the Earth's mantle. Am. Sci., 48(2):254-263. http://www.jstor.org/stable/ 27827541

Hey, R., Johnson, G.L., and Lowrie, A., 1977. Recent plate motions in the Galapagos area. Geol. Soc. Am. Bull., 88(10):1385-1403. doi:10.1130/00167606(1977)88<1385:RPMITG >2.0.CO;2

Hey, R.N., Deffeyes, K.S., Johnson, G.L., and Lowrie, A., 1972. The Galapagos triple junction and plate motions in the East Pacific. Nature (London, U. K.), 237(5349)2022. doi: $10.1038 / 237020 \mathrm{a} 0$

Holden, J.C., and Dietz, R.S., 1972. Galapagos gore, NazCoPac triple junction and Carnegie/Cocos Ridges. Nature (London, U. K.), 235(5336):266-269. doi:10.1038/ 235266a0

Hooft, E.E.E., Detrick, R.S., and Kent, G.M., 1997. Seismic structure and indicators of magma budget along the southern East Pacific Rise. J. Geophys. Res.: Solid Earth, 102(B12):27319-27340. doi:10.1029/97JB02349

Karson, J.A., Hurst, S.D., and Lonsdale, P., 1992. Tectonic rotations of dikes in fast-spread oceanic crust exposed near Hess Deep. Geology, 20(8):685-688. doi:10.1130/ 0091-7613(1992)020<0685:TRODIF>2.3.CO;2

Karson, J.A., Klein, E.M., Hurst, S.D., Lee, C.E., Rivizzigno, P.A., Curewitz, D., Morris, A.R., Miller, D.J., Varga, R.G., Christeson, G.L., Cushman, B., O'Neill, J.M., Brophy, J.G., Gillis, K.M., Stewart, M.A., and Sutton, A.L., 2002. Structure of uppermost fast-spread oceanic crust exposed at the Hess Deep Rift: implications for subaxial processes at the East Pacific Rise. Geochem., Geophys., Geosyst., 3(1):1002. doi:10.1029/2001GC000155

Kelemen, P.B., and Aharonov, E., 1998. Periodic formation of magma fractures and generation of layered gabbros in the lower crust beneath oceanic spreading ridges. In Buck, R., Delaney, P.T., Karson, J.A., and Lagabrielle, Y. (Eds.), Faulting and Magmatism at Mid-Ocean Ridges. Geophys. Monogr., 106:267-289. doi:10.1029/ GM106p0267

Kelemen, P.B., Koga, K., and Shimizu, N., 1997. Geochemistry of gabbro sills in the crust-mantle transition zone of the Oman ophiolite: implications for the origin of 
the oceanic lower crust. Earth Planet. Sci. Lett., 146(34):475-488. doi:10.1016/S0012-821X(96)00235-X

Kent, G.M., Harding, A.J., and Orcutt, J.A., 1990. Evidence for a smaller magma chamber beneath the East Pacific Rise at $9^{\circ} 30^{\prime} \mathrm{N}$. Nature (London, U. K.), 344(6267):650653. doi:10.1038/344650a0

Kirchner, T.M., and Gillis, K.M., 2012. Mineralogical and strontium isotopic record of hydrothermal processes in the lower ocean crust at and near the East Pacific Rise. Contrib. Mineral. Petrol., 164(1):123-141 doi:10.1007/ s00410-012-0729-5

Klein, E.M., 2007. Geochemistry of the igneous oceanic crust. Treatise Geochem., 3:433-463. doi:10.1016/B0-08043751-6/03030-9

Koepke, J., Berndt, J., Feig, S.T., and Holtz, F., 2007. The formation of $\mathrm{SiO}_{2}$-rich melts within the deep ocean crust by hydrous partial melting of gabbros. Contrib. Mineral. Petrol., 153(1):67-84. doi:10.1007/s00410-0060135-y

Koepke, J., France, L., Müller, T., Faure, F., Goetze, N., Dziony, W., and Ildefonse, B., 2011. Gabbros from IODP Site 1256, equatorial Pacific: insight into axial magma chamber processes at fast spreading ocean ridges. Geochem., Geophys., Geosyst., 12(9):Q09014. doi:10.1029/ 2011GC003655

Korenaga, J., and Kelemen, P.B., 1997. Origin of gabbro sills in the Moho transition zone of the Oman ophiolite: implications for magma transport in the oceanic lower crust. J. Geophys. Res.: Solid Earth, 102(B12):27729-27749. doi:10.1029/97JB02604

Korenaga, J., and Kelemen, P.B., 1998. Melt migration through the oceanic lower crust: a constraint from melt percolation modeling with finite solid diffusion. Earth Planet. Sci. Lett., 156(1-2):1-11. doi:10.1016/ S0012-821X(98)00004-1

Lécuyer, C., and Gruau, G., 1996. Oxygen and strontium isotope compositions of Hess Deep gabbros (Holes 894F and 894G): high-temperature interaction of seawater with the oceanic crust Layer 3. In Mével, C., Gillis, K.M., Allan, J.F., and Meyer, P.S. (Eds.), Proc. ODP, Sci. Results, 147: College Station, TX (Ocean Drilling Program), 227234. doi:10.2973/odp.proc.sr.147.014.1996

Lecuyer, C., and Reynard, B., 1996. High-temperature alteration of oceanic gabbros by seawater (Hess Deep, Ocean Drilling Program Leg 147): evidence from oxygen isotopes and elemental fluxes. J. Geophys. Res.: Solid Earth, 101(B7):15883-15897. doi:10.1029/96JB00950

Lissenberg, C.J., MacLeod, C.J., Howard, K.A., and Godard, M., 2013. Pervasive reactive melt migration through fast-spreading lower oceanic crust (Hess Deep, equatorial Pacific Ocean). Earth Planet. Sci. Lett., 361:436-447. doi:10.1016/j.epsl.2012.11.012

Lonsdale, P., 1988. Structural pattern of the Galapagos microplate and evolution of the Galapagos triple junctions. J. Geophys. Res. [Solid Earth], 93(B11):1355113574. doi:10.1029/JB093iB11p13551

Lonsdale, P., 1989. Segmentation of the Pacific-Nazca spreading center, $1^{\circ} \mathrm{N}-20^{\circ} \mathrm{S}$. J. Geophys. Res.: Solid Earth, 94(B9):12197-12225. doi:10.1029/JB094iB09p12197
Maclennan, J., Hulme, T., and Singh, S.C., 2004. Thermal models of oceanic crustal accretion: linking geophysical, geological, and petrological observations. Geochem., Geophys., Geosyst., 5(2):Q02F25. doi:10.1029/ 2003GC000605

MacLeod, C.J., Boudier, F., Yaouancq, G., and Richter, C., 1996a. Gabbro fabrics from Site 894, Hess Deep: implications for magma chamber processes at the East Pacific Rise. In Mével, C., Gillis, K.M., Allan, J.F., and Meyer, P.S. (Eds.), Proc. ODP, Sci. Results, 147: College Station, TX (Ocean Drilling Program), 317-328. doi:10.2973/ odp.proc.sr.147.018.1996

MacLeod, C.J., Célérier, B., Früh-Green, G.L., and Manning, C.E., 1996b. Tectonics of Hess Deep: a synthesis of drilling results from Leg 147. In Mével, C., Gillis, K.M., Allan, J.F., and Meyer, P.S. (Eds.), Proc. ODP, Sci. Results, 147: College Station, TX (Ocean Drilling Program), 461475. doi:10.2973/odp.proc.sr.147.032.1996

MacLeod, C.J., Teagle, D.A., Gillis, K.M., Shillington, D.J., and Scientific Party, 2008. Morphotectonics of Hess Deep: preliminary results of RSS James Cook Cruise JC21. Eos, Trans. Am. Geophys. Union, 89(53)(Suppl.):V43I-408 (Abstract). http://www.agu.org/meetings/fm08/ waisfm08.html

MacLeod, C.J., and Yaouancq, G., 2000. A fossil melt lens in the Oman ophiolite: implications for magma chamber processes at fast spreading ridges. Earth Planet. Sci. Lett., 176(3-4):357-373. doi:10.1016/S0012821X(00)00020-0

Manning, C.E., and MacLeod, C.J., 1996. Fracture-controlled metamorphism of Hess Deep gabbros, Site 894: constraints on the roots of mid-ocean-ridge hydrothermal systems at fast-spreading centers. In Mével, C., Gillis, K.M., Allan, J.F., and Meyer, P.S. (Eds.), Proc. ODP, Sci. Results, 147: College Station, TX (Ocean Drilling Program), 189-212. doi:10.2973/ odp.proc.sr.147.011.1996

Manning, C.E., Weston, P.E., and Mahon, K.I., 1996. Rapid high-temperature metamorphism of East Pacific Rise gabbros from Hess Deep. Earth Planet. Sci. Lett., 144(12):123-132. doi:10.1016/0012-821X(96)00153-7

Mathison, C.I., 1987. Cyclic units in the Somerset Dam layered gabbro intrusion, southeastern Queensland, Australia. Lithos, 20(3):187-205. doi:10.1016/00244937(87)90008-9

McCollom, T.M., and Shock, E.L., 1998. Fluid-rock interactions in the lower oceanic crust: thermodynamic models of hydrothermal alteration. J. Geophys. Res.: Solid Earth, 103(B1):547-575. doi:10.1029/97JB02603

Melson, W.G., and Thompson, G., 1970. Layered basic complex in oceanic crust, Romanche fracture, equatorial Atlantic Ocean. Science, 168(3933):817-820. doi:10.1126/science.168.3933.817

Meurer, W.P., and Gee, J., 2002. Evidence for the protracted construction of slow-spread oceanic crust by small magmatic injections. Earth Planet. Sci. Lett., 201(1):45-55. doi:10.1016/S0012-821X(02)00660-X

Miller, D.J., Iturrino, G.J., and Christensen, N.I., 1996. Geochemical and petrological constraints on velocity behavior of lower crustal and upper mantle rocks from 
the fast-spreading ridge at Hess Deep. In Mével, C., Gillis, K.M., Allan, J.F., and Meyer, P.S. (Eds.), Proc. ODP, Sci. Results, 147: College Station, TX (Ocean Drilling Program), 477-490. doi:10.2973/

odp.proc.sr.147.028.1996

Morris, A., Gee, J.S., Pressling, N., John, B.E., MacLeod, C.J., Grimes, C.B., and Searle, R.C., 2009. Footwall rotation in an oceanic core complex quantified using reoriented Integrated Ocean Drilling Program core samples. Earth Planet. Sci. Lett., 287(1-2):217-228. doi:10.1016/ j.epsl.2009.08.007

Morton, J.L., and Sleep, N.H., 1985. A mid-ocean ridge thermal model: constraints on the volume of axial hydrothermal heat flux. J. Geophys. Res.: Solid Earth, 90(B13):11345-11353. doi:10.1029/JB090iB13p11345

Natland, J.H., and Dick, H.J.B., 1996. Melt migration through high-level gabbroic cumulates of the East Pacific Rise at Hess Deep: the origin of magma lenses and the deep crustal structure of fast-spreading ridges. In Mével, C., Gillis, K.M., Allan, J.F., and Meyer, P.S. (Eds.), Proc. ODP, Sci. Results, 147: College Station, TX (Ocean Drilling Program), 21-58. doi:10.2973/ odp.proc.sr.147.002.1996

Nicolas, A., 1989. Structure of Ophiolites and Dynamics of the Oceanic Lithosphere: Dordrecht (Springer).

Nicolas, A., Reuber, I., and Benn, K., 1988. A new magma chamber model based on structural studies in the Oman ophiolite. Tectonophysics, 151(1-4):87-105. doi:10.1016/0040-1951(88)90242-9

Nozaka, T., and Fryer, P., 2011. Alteration of the oceanic lower crust at a slow-spreading axis: insight from veinrelated zoned halos in olivine gabbro from Atlantis Massif, Mid-Atlantic Ridge. J. Petrol., 52(4):643-664. doi:10.1093/petrology/egq098

O'Driscoll, B., Donaldson, C.H., Troll, V.R., Jerram, D.A., and Emeleus, C.H., 2007. An origin for harrisitic and granular olivine in the Rum Layered Suite, NW Scotland: a crystal size distribution study. J. Petrol., 48(2):253-270. doi:10.1093/petrology/eg1059

O'Hara, M.J., 1968. Are ocean floor basalts primary magma? Nature (London, U. K.), 220(5168):683-686. doi:10.1038/220683a0

Olmsted, J.F., 1979. Crystallization history and textures of the rearing pond gabbro, northwestern Wisconsin. Am. Mineral., 64(7-8):844-855.

Pallister, J.S., and Hopson, C.A., 1981. Samail ophiolite plutonic suite: field relations, phase variation, cryptic variation and layering, and a model of a spreading ridge magma chamber. J. Geophys. Res.: Solid Earth, 86(B4):2593-2644. doi:10.1029/JB086iB04p02593

Pariso, J.E., Kelso, P., and Richter, C., 1996. Paleomagnetism and rock magnetic properties of gabbro from Hole 894G, Hess Deep. In Mével, C., Gillis, K.M., Allan, J.F., and Meyer, P.S. (Eds.), Proc. ODP, Sci. Results, 147: College Station, TX (Ocean Drilling Program), 373-381. doi:10.2973/odp.proc.sr.147.023.1996

Pedersen, R.B., Malpas, J., and Falloon, T., 1996. Petrology and geochemistry of gabbroic and related rocks from Site 894, Hess Deep. In Mével, C., Gillis, K.M., Allan, J.F., and Meyer, P.S. (Eds.), Proc. ODP, Sci. Results, 147: Col- lege Station, TX (Ocean Drilling Program), 3-19. doi:10.2973/odp.proc.sr.147.001.1996

Perk, N.W., Coogan, L.A., Karson, J.A., Klein, E.M., and Hanna, H.D., 2007. Petrology and geochemistry of primitive lower oceanic crust from Pito Deep: implications for the accretion of the lower crust at the southern East Pacific Rise. Contrib. Mineral. Petrol., 154(5):575590. doi:10.1007/s00410-007-0210-z

Phipps Morgan, J., and Chen, Y.J., 1993. The genesis of oceanic crust: magma injection, hydrothermal circulation, and crustal flow. J. Geophys. Res.: Solid Earth, 98(B4):6283-6297. doi:10.1029/92JB02650

Quick, J.E., and Denlinger, R.P., 1993. Ductile deformation and the origin of layered gabbro in ophiolites. J. Geophys. Res.: Solid Earth, 98(B8):14015-14027. doi:10.1029/93JB00698

Richter, C., Kelso, P.R., and MacLeod, C.J., 1996. Magnetic fabrics and sources of magnetic susceptibility in lower crustal and upper mantle rocks from Hess Deep. In Mével, C., Gillis, K.M., Allan, J.F., and Meyer, P.S. (Eds.), Proc. ODP, Sci. Results, 147: College Station, TX (Ocean Drilling Program), 393-403. doi:10.2973/ odp.proc.sr.147.025.1996

Rioux, M., Lissenberg, C.J., McLean, N.M., Bowring, S.A., MacLeod, C.J., Hellebrand, E., and Shimizu, N., 2012. Protracted timescales of lower crustal growth at the fastspreading East Pacific Rise. Nat. Geosci., 5(4):275-278. doi:10.1038/ngeo1378

Ryan, W.B.F., Carbotte, S.M., Coplan, J.O., O'Hara, S., Melkonian, A., Arko, R., Weissel, R.A., Ferrini, V., Goodwillie, A., Nitsche, F., Bonczkowski, J., and Zemsky, R., 2009. Global multi-resolution topography synthesis. Geochem., Geophys., Geosyst., 10(3):Q03014. doi:10.1029/2008GC002332

Saunders, A.D., Fornari, D.J., Joron, J.-L., Tarney, J., and Treuil, M., 1982. Geochemistry of basic igneous rocks, Gulf of California, Deep Sea Drilling Project Leg 64. In Curray, J.R., Moore, D.G., et al. (Eds.), Init. Repts. DSDP, 64: Washington, DC (U.S. Govt. Printing Office), 595642. doi:10.2973/dsdp.proc.64.112.1982

Schouten, H., Smith, D.K., Montési, L.G.J., Zhu, W., and Klein, E.M., 2008. Cracking of lithosphere north of the Galapagos triple junction. Geology, 36(5):339-342. doi:10.1130/G24431A.1

Singh, S.C., Kent, G.M., Collier, J.S., Harding, A.J., and Orcutt, J.A., 1998. Melt to mush variations in crustal magma properties along the ridge crest at the southern East Pacific Rise. Nature (London, U. K.), 394(6696):874878. doi:10.1038/29740

Sleep, N.H., 1975. Formation of oceanic crust: some thermal constraints. J. Geophys. Res.: Solid Earth, 80(29):4037-4042. doi:10.1029/JB080i029p04037

Smith, D.K., Schouten, H., Zhu, W., Montési, L.G.J., and Cann, J.R., 2011. Distributed deformation ahead of the Cocos-Nazca Rift at the Galapagos triple junction. Geochem., Geophys., Geosyst., 12(6):Q11003. doi:10.1029/ 2011GC003689

Stewart, M.A., Klein, E.M., and Karson, J.A., 2002. Geochemistry of dikes and lavas from the north wall of the Hess Deep Rift: insights into the four-dimensional char- 
acter of crustal construction at fast-spreading mid-ocean ridges. J. Geophys. Res.: Solid Earth, 107(B10):2238. doi:10.1029/2001JB000545

Stolper, E., and Walker, D., 1980. Melt density and the average composition of basalt. Contrib. Mineral. Petrol., 74(1):7-12. doi:10.1007/BF00375484

Teagle, D.A.H., Bickle, M.J., and Alt, J.C., 2003. Recharge flux to ocean-ridge black smoker systems: a geochemical estimate from ODP Hole 504B. Earth Planet. Sci. Lett., 210(1-2):81-89. doi:10.1016/S0012-821X(03)00126-2

Teagle, D.A.H., Ildefonse, B., Blum, P., and the Expedition 335 Scientists, 2012. Proc. IODP, 335: Tokyo (Integrated Ocean Drilling Program Management International, Inc.). doi:10.2204/iodp.proc.335.2012

Wiggins, S.M., Dorman, L.M., Cornuelle, B.D., and Hildebrand, J.A., 1996. Hess Deep rift valley structure from seismic tomography. J. Geophys. Res.: Solid Earth, 101(B10):22335-22353. doi:10.1029/96JB01230

Wilson, D.S., Teagle, D.A.H., Alt, J.C., Banerjee, N.R., Umino, S., Miyashita, S., Acton, G.D., Anma, R., Barr, S.R., Belghoul, A., Carlut, J., Christie, D.M., Coggon,
R.M., Cooper, K.M., Cordier, C., Crispini, L., Durand, S.R., Einaudi, F., Galli, L., Gao, Y., Geldmacher, J., Gilbert, L.A., Hayman, N.W., Herrero-Bervera, E., Hirano, N., Holter, S., Ingle, S., Jiang, S., Kalberkamp, U., Kerneklian, M., Koepke, J., Laverne, C., Vasquez, H.L.L., Maclennan, J., Morgan, S., Neo, N., Nichols, H.J., Park, S.-H., Reichow, M.K., Sakuyama, T., Sano, T., Sandwell, R., Scheibner, B., Smith-Duque, C.E., Swift, S.A., Tartarotti, P., Tikku, A.A., Tominaga, M., Veloso, E.A., Yamasaki, T., Yamazaki, S., and Ziegler, C., 2006. Drilling to gabbro in intact ocean crust. Science, 312(5776):1016-1020. doi:10.1126/science.1126090

Parsons, I. (Ed.), 1986. Origins of Igneous Layering: Dordrecht, Holland (D. Reidel Publ.).

Zonenshain, L.P., Kogan, L.I., Savostin, L.A., Golmstock, A.J., and Gorodnitskii, A.M., 1980. Tectonics, crustal structure and evolution of the Galapagos triple junction. Mar. Geol., 37(3-4):209-230. doi:10.1016/ 0025-3227(80)90102-4

Publication: 12 February 2014 MS 345-101 
Figure F1. Schematic models for the ocean crust showing how its structure changes with decreasing magmatism and increasing faulting from A to D. Modified after Dick et al. (2006). A. Fast-spreading crust, after the Penrose standard layered model (Anonymous, 1972). Red bars = major deep drilling sites, dashed blue bar = drilling target area for Expedition 345. Moho $=$ Mohorovicic discontinuity. B. Slow-spreading crust formed at a segment center (Cannat et al., 1995). C. Slow-spreading crust formed at a segment end (Cannat et al., 1995). D. Ultraslow-spreading crust, which is the nearly nonvolcanic end-member of crustal construction (Dick et al., 2006).

\section{Slow-spreading ridge}

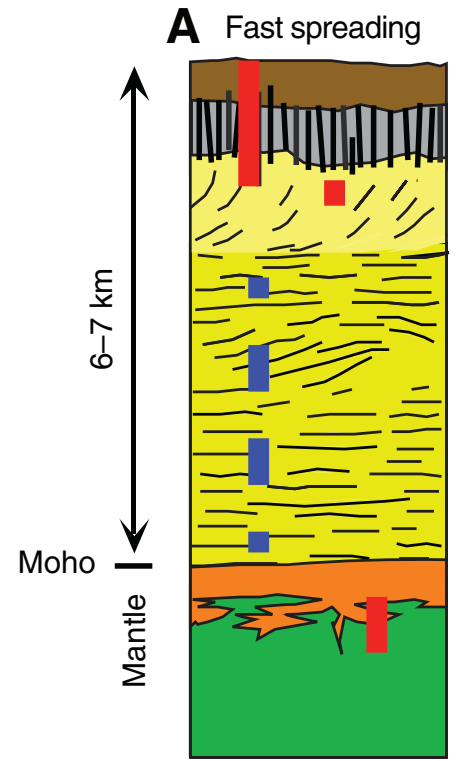

Sites 504,1256 Sites 894, 895

Site U1415

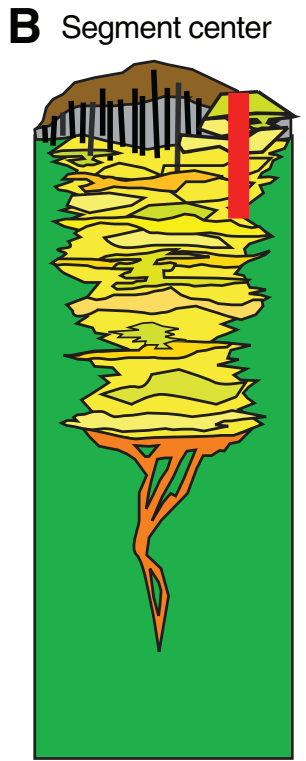

Site 735

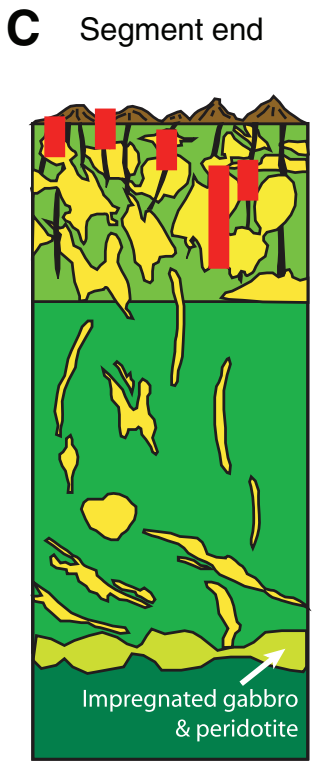

Legs 153, 209 Site U1309
D Ultraslow spreading

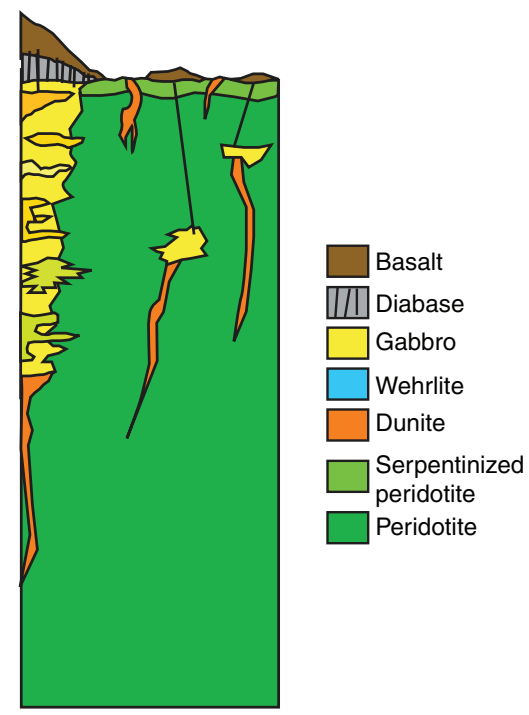

Nothing

yet 
Figure F2. Schematic drawings of crustal accretion models (modified from Korenaga and Kelemen, 1997). Black arrows $=$ movement of the crystal mush, blue arrows $=$ dominant zones where hydrothermal circulation removes latent and sensible heat. A. Gabbro glacier in which the lower oceanic crust crystallizes in a thin magma lens at the base of the sheeted dike complex from which cumulates subside downward and outward to form the lower crust (e.g., Henstock et al., 1993; Phipps Morgan and Chen, 1993; Quick and Denlinger, 1993). B. Hybrid model in which some crystallization occurs in an upper melt lens and some within sill-like bodies in the lower crust (e.g., Boudier et al., 1996). C. "Sheeted" or "stacked" sill model in which the lower ocean crust forms by crystallization of multiple sill-like intrusions (e.g., Bédard et al., 1988; Kelemen and Aharonov, 1998; Kelemen et al., 1997).
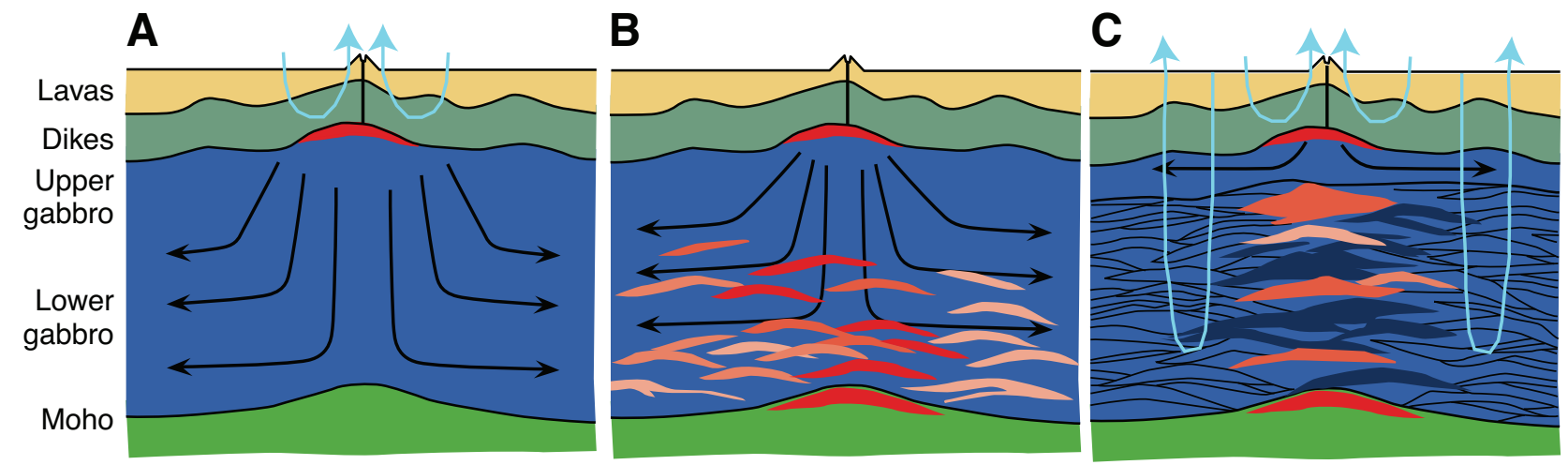
Figure F3. Schematic representation of the predictions of the general depth trends of latent heat release, bulk Mg\#, strain, cooling rate, hydrothermal fluid flux, fluid temperature, and intensity of high-temperature (HT) alteration for the end-member "gabbro glacier" (with mainly conductive cooling of the lower crust) and "sheeted sill" (with convective cooling of the lower crust) models (Teagle, Ildefonse, Blum, and the Expedition 335 Scientists, 2012; original figure by R. Coggon).

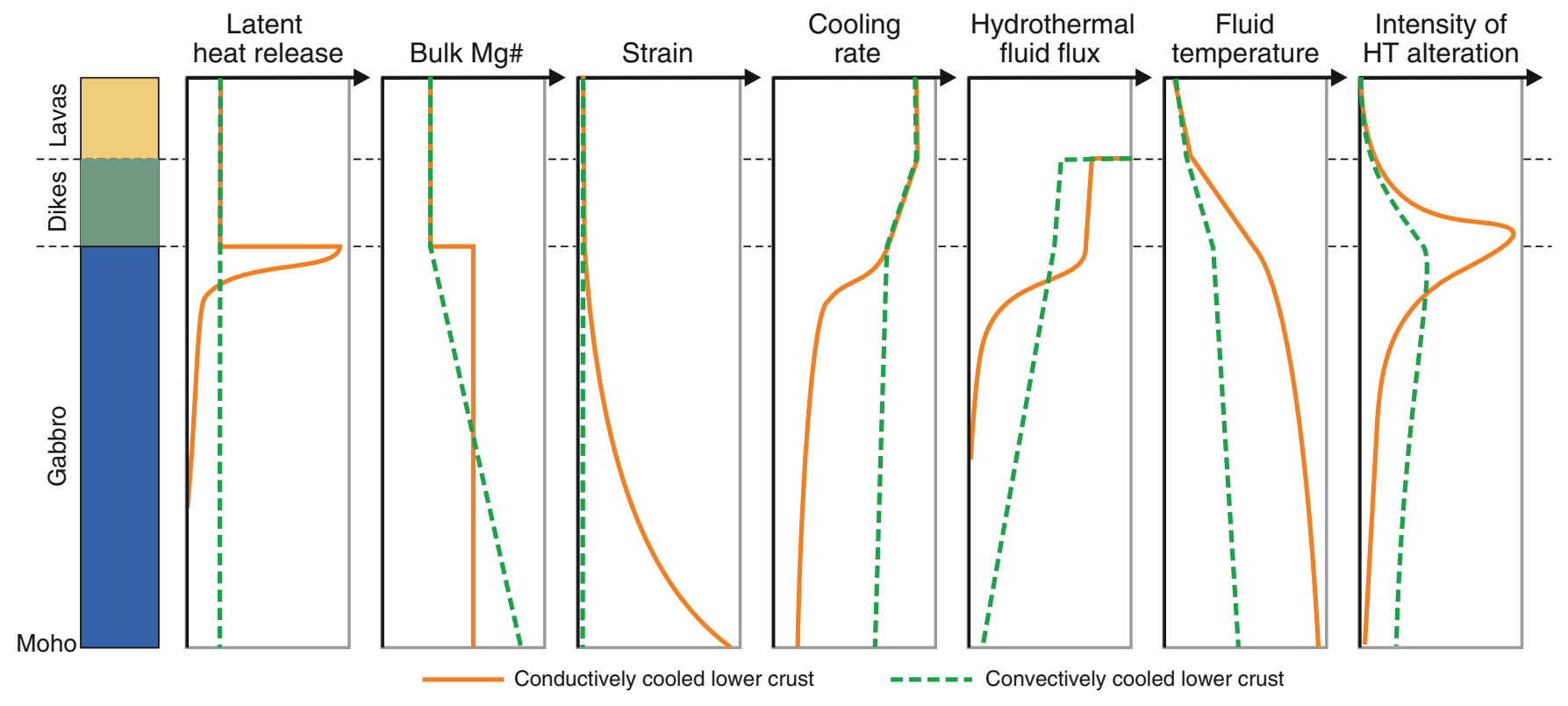


Figure F4. Map of the Galapagos triple junction in the eastern equatorial Pacific Ocean showing bathymetry derived from satellite altimetry data and archived multibeam bathymetry data available from the Global MultiResolution Topography Data Portal at Lamont-Doherty Earth Observatory. The map was generated using GeoMapApp (Ryan et al., 2009). Tectonic boundaries modified from Smith et al. (2011). EPR = East Pacific Rise, TJ = triple junction. Red box with dashed lines indicates location of the map in Figure F5.

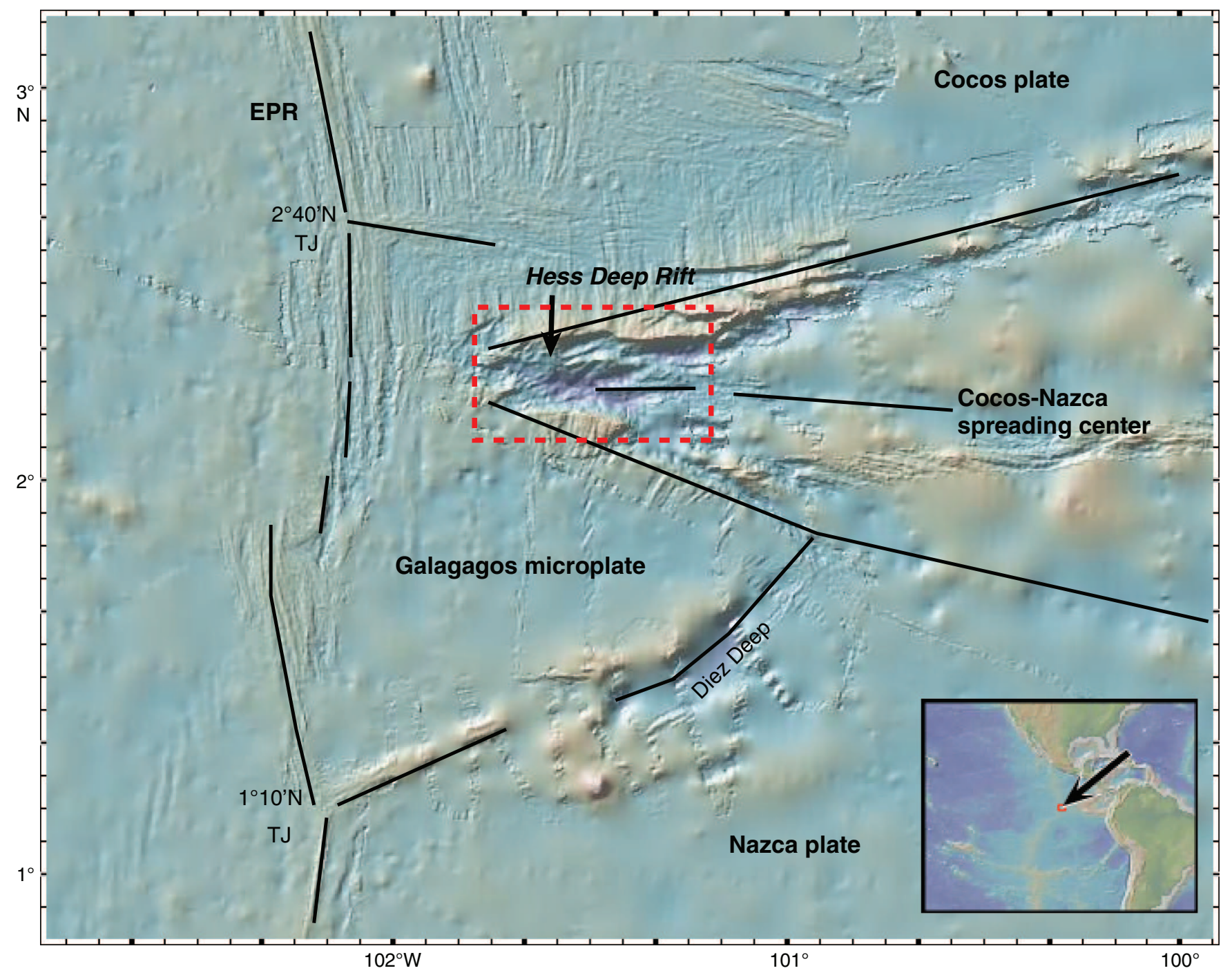


Figure F5. Regional bathymetric map of the Hess Deep Rift showing key morphological features and locations of IODP Expedition 345 Site U1415 and ODP Sites 894 and 895. Swath data were gridded at between 50 and $150 \mathrm{~m}$ depending on the density of data coverage, with the smallest grid spacing in the center of Hess Deep. Data available from the Marine Geoscience Data System (www.marine-geo.org) from cruises aboard the R/V Thomas Washington in 1982 (PI: P. Lonsdale), 1985 (PI: Lonsdale), and 1992 (PI: L. Dorman), and aboard the R/V Melville in 2000 (PI: D. Fornari) and 2002 (PI: E. Klein) were combined with data collected during the JC-21 site survey cruise in 2008 (MacLeod et al., unpubl. data).
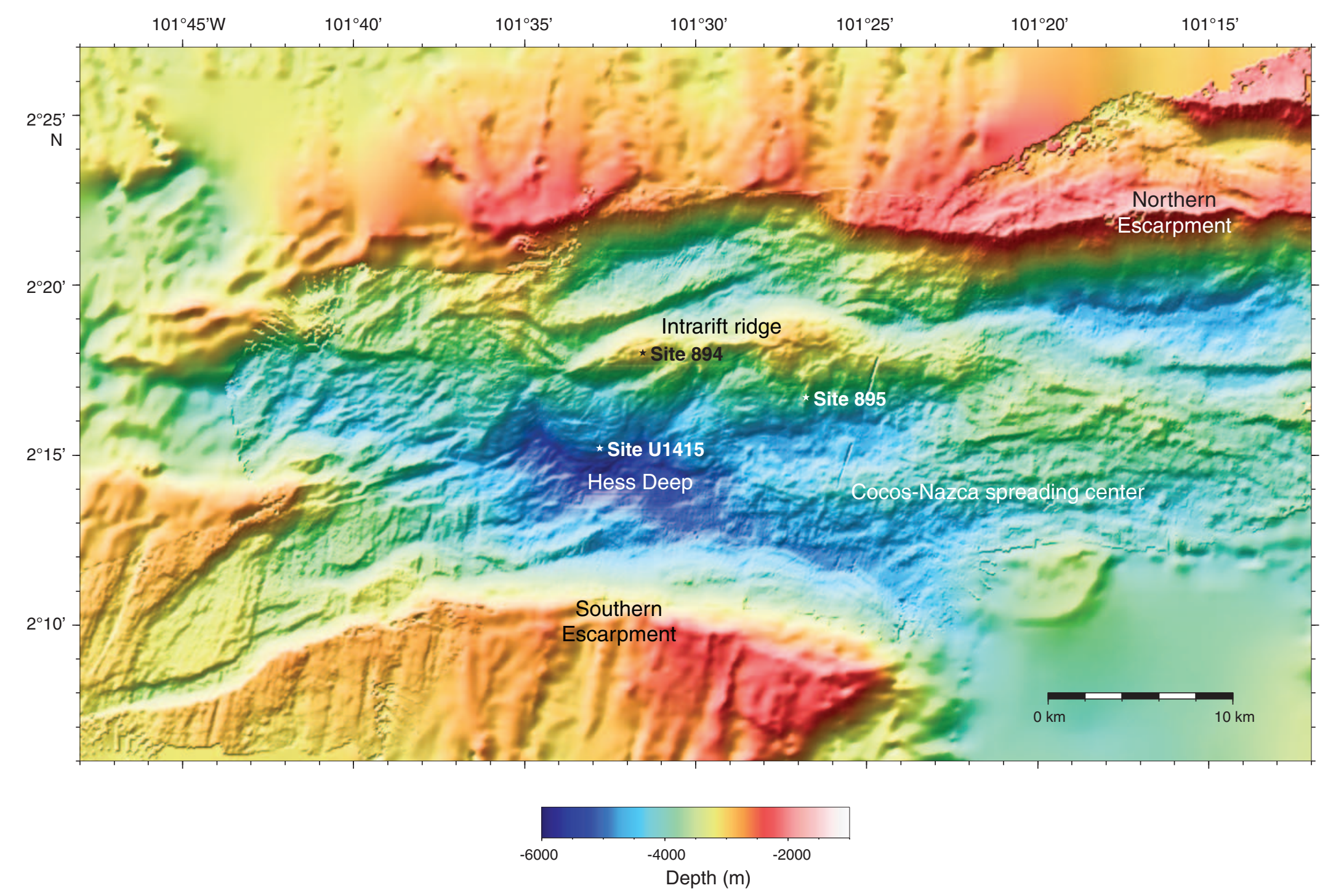
Figure F6. Bathymetric map of the western end of the intrarift ridge and its southern slope showing the distribution of rock types recovered during the NazCoPac submersible cruise (triangles) (Francheteau et al., 1990; Hékinian et al., 1993) and the JC-21 site survey cruise (circles) (MacLeod et al., unpubl. data). Box indicates the area of a smaller scale map of the southern slope shown in Figure F8. See Figure F5 for bathymetric data sources. Contour interval $=100 \mathrm{~m}$.

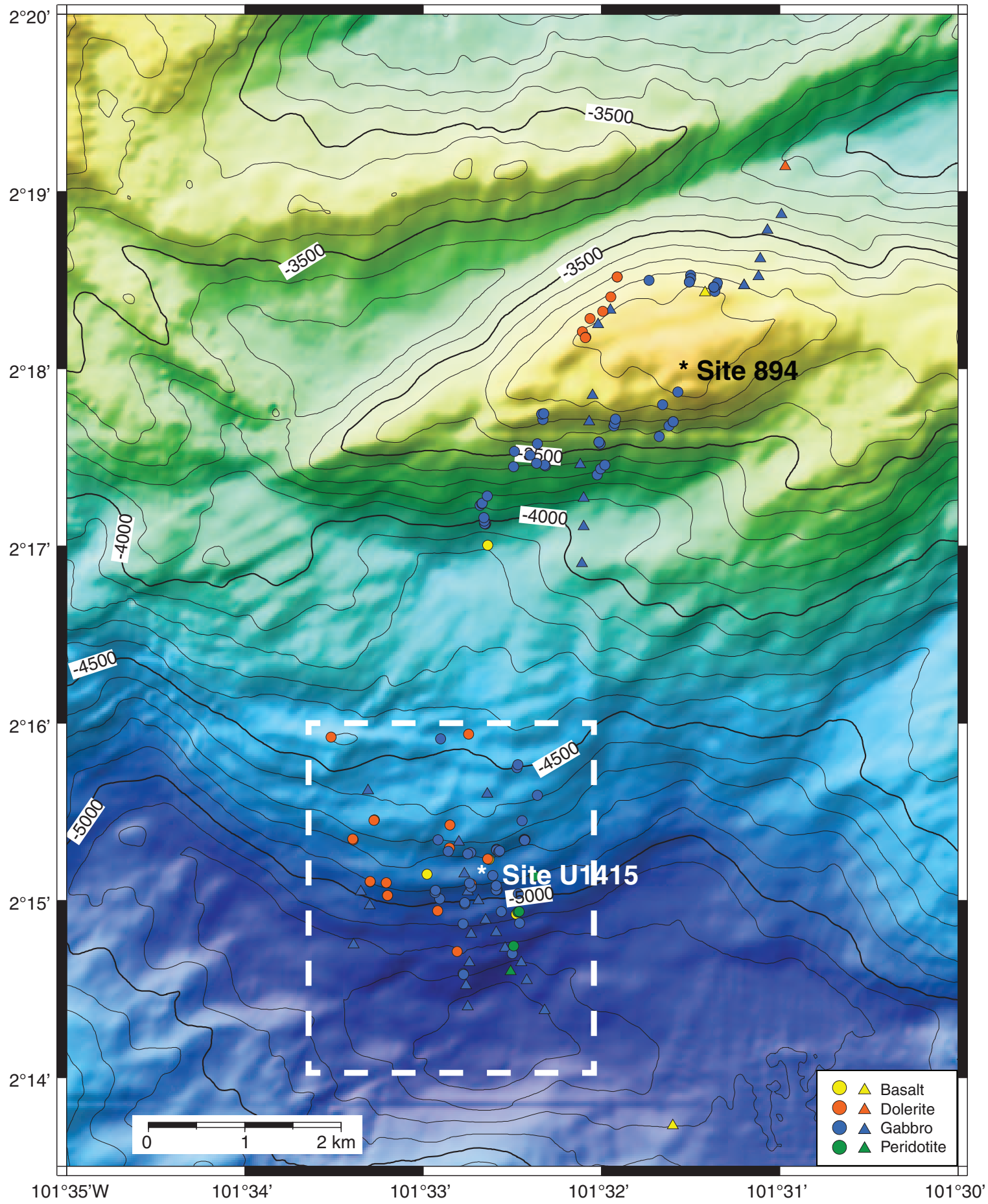


Figure F7. Contoured microbathymetry map for the southern slope of the intrarift ridge between 4300 and 5400 mbsl showing the location and rock type of samples recovered during the JC21 site survey cruise by the ROV Isis (circles; MacLeod et al., unpubl. data) and the submersible Nautile during the NazCoPac cruise (triangles; Francheteau et al., 1990). Rock types were determined by shore-based petrographic analysis (MacLeod, pers. comm., 2009; Hékinian et al., 1993). Microbathymetry data were acquired at a nominal altitude of $\sim 100$ $\mathrm{m}$ and speed of $0.3 \mathrm{kt}$ by a Simrad SM2000 (200 kHz) multibeam sonar system mounted on the Isis. Swath widths during Isis surveys were $200-350 \mathrm{~m}$ depending on noise and seabed characteristics (dip and reflectivity). See Figure F6 for location within the Hess Deep Rift. The dashed line outlines the area surrounding Site U1415 shown in Figure F17. Note that the NazCoPac samples are not precisely located, as the dive tracks were not transponder navigated. Map prepared by D. Shillington and V. Ferrini. Contour interval $=20 \mathrm{~m}$.

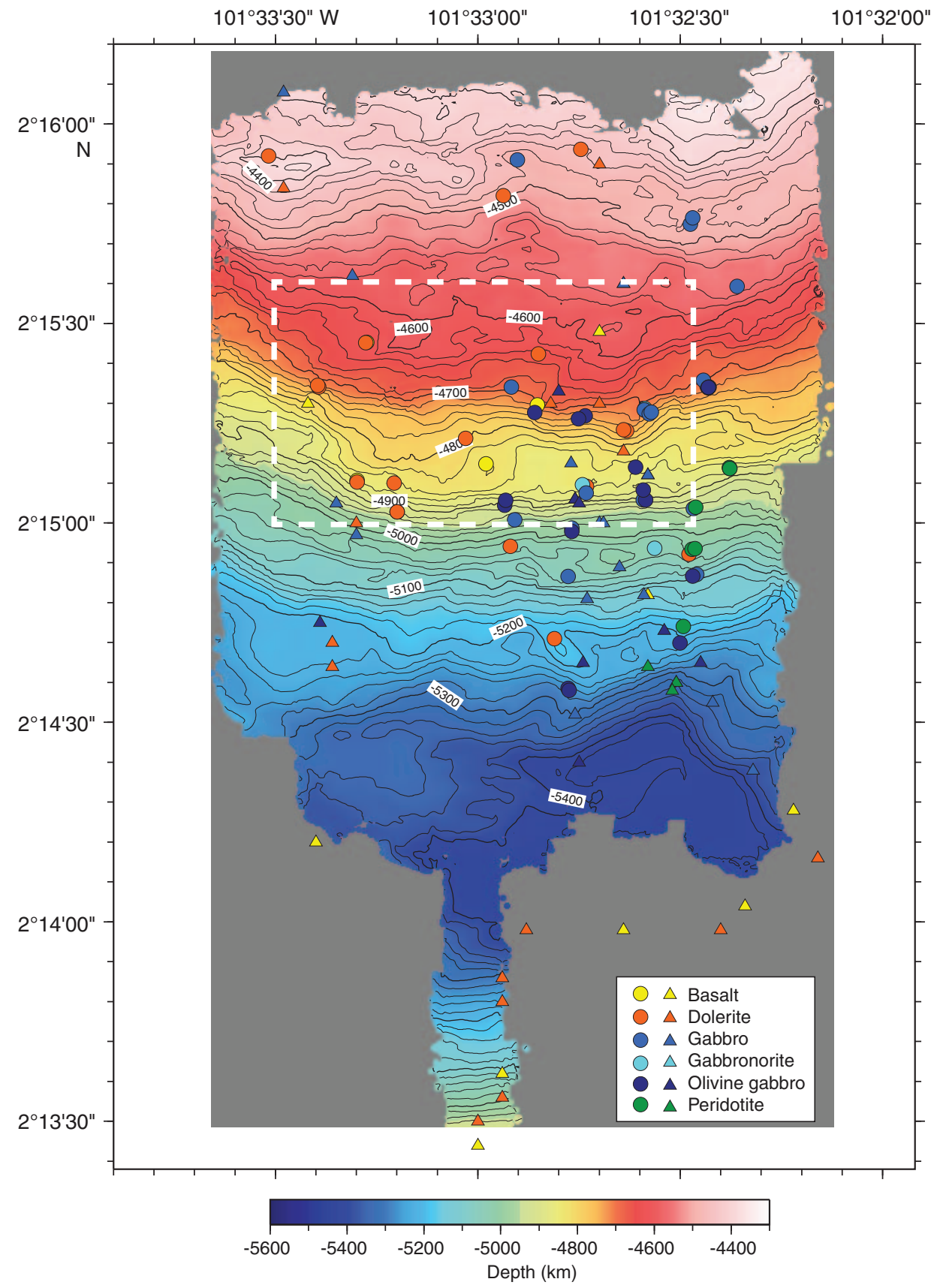


Figure F8. Bathymetric map with locations of Site U1415 drill holes. See Figure F9 for close-up of outlined area at the eastern end of the bench.

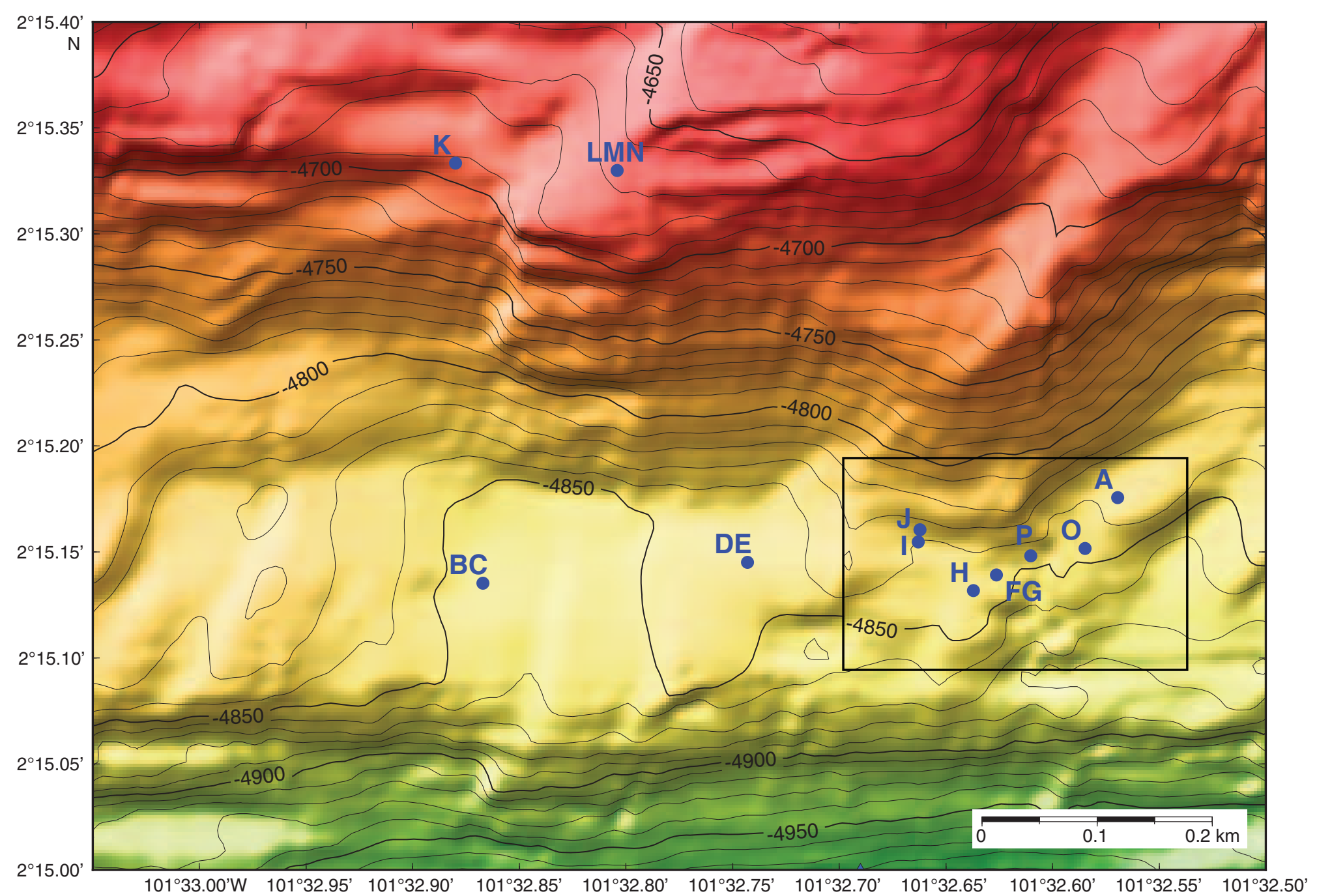


Figure F9. Bathymetric map detail of Site U1415 drill hole locations at the eastern end of the bench outlined in Figure F8.

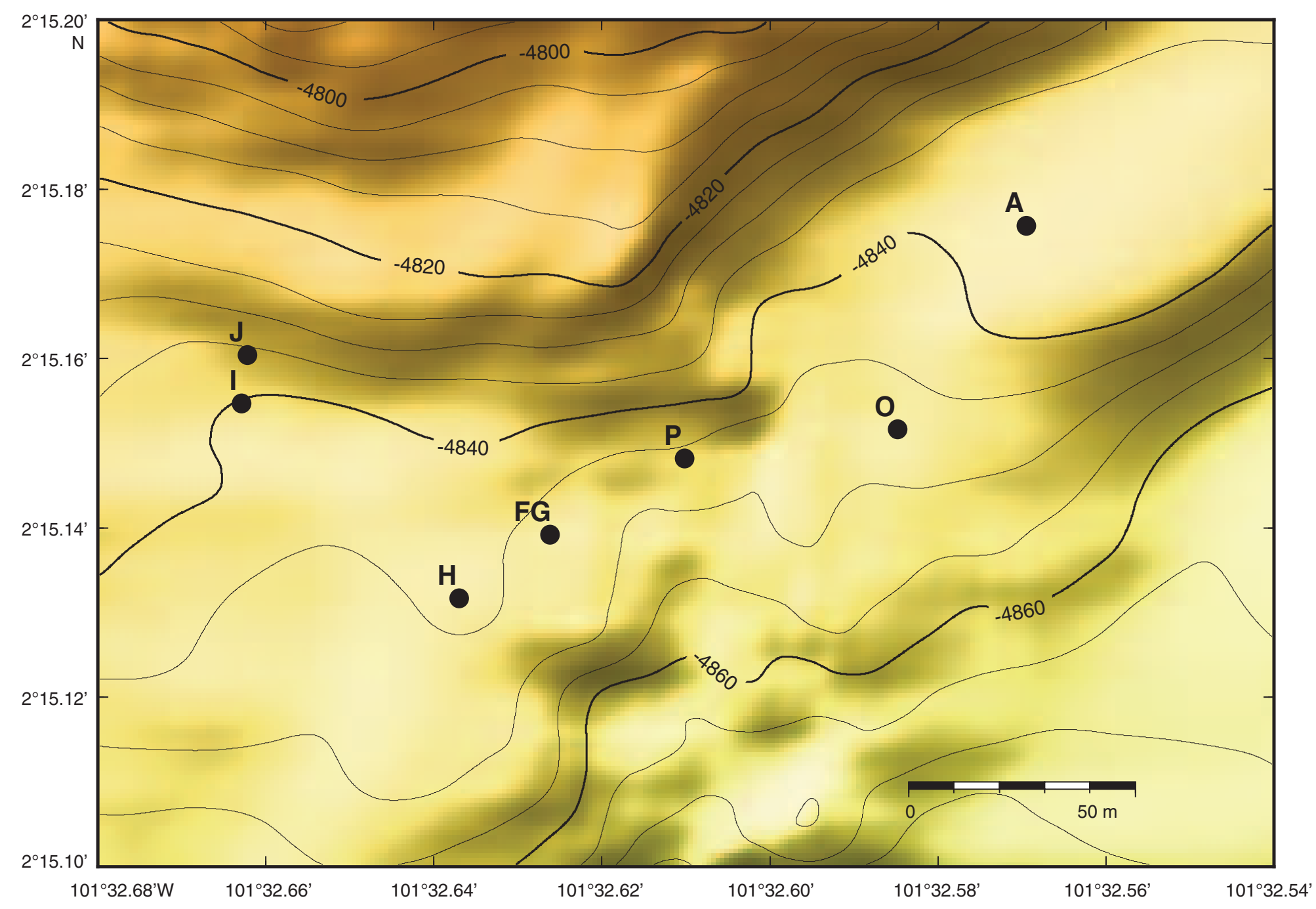


Figure F10. Summary of shipboard results, Hole U1415J. Cored intervals are shaded gray. "Others" includes dolerite, basalt, altered chromitite, and cataclasite. Ghost core Cluster 1 includes Cores 345-U1415J-6G, 7G, and 15G and ghost core Cluster 2 includes Cores 14G, 17G, 22G, 24G, and 25G. Magmatic structures include foliations and modal layers; modal layers are always subparallel to the foliations. Inclination of magnetic remanence (only well-constrained values) and $P$-wave velocity were measured on discrete shipboard samples. Note that the horizontal scale for orthopyroxene (Opx) percentage is logarithmic. TS = shipboard thin sections.

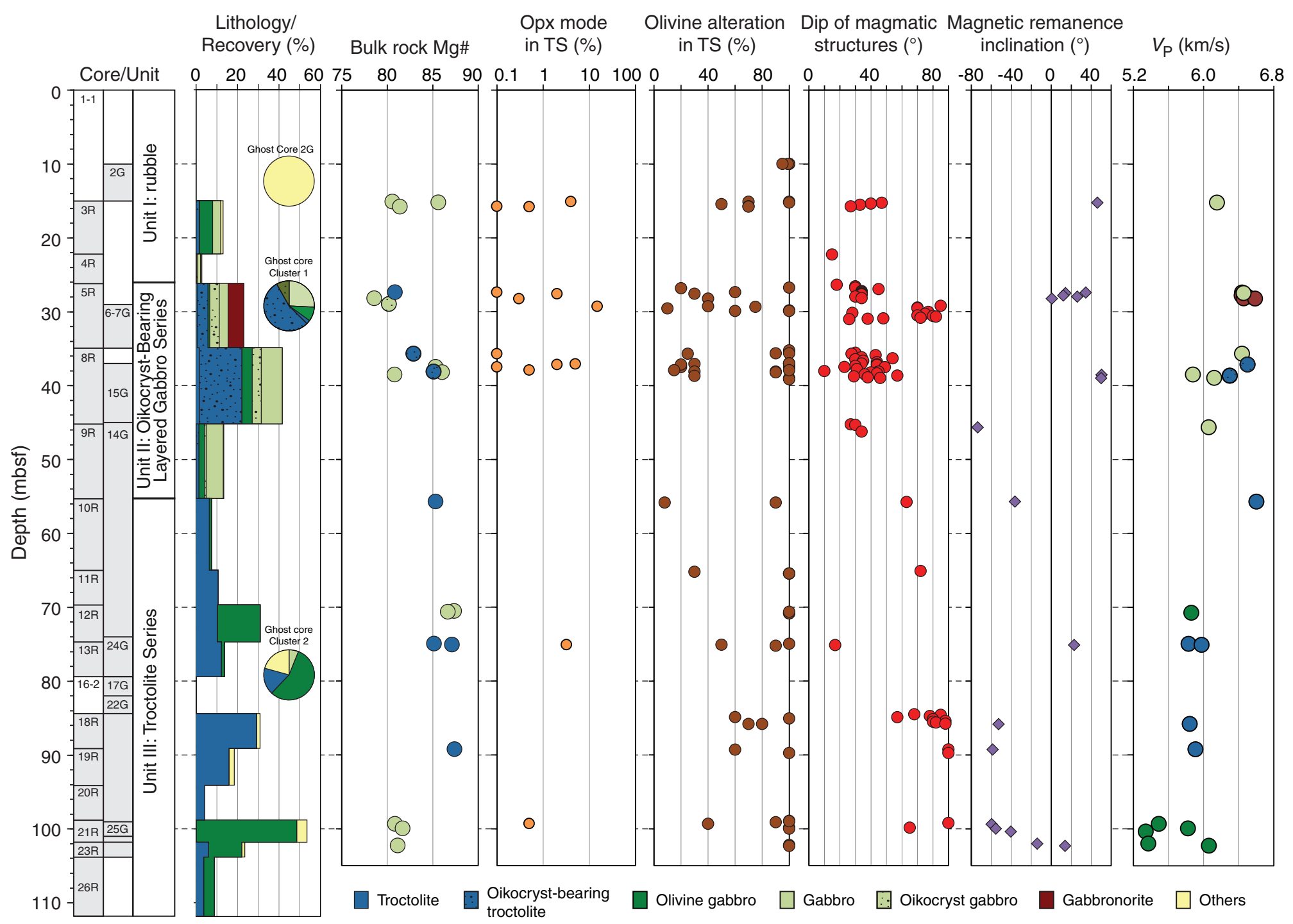


Figure F11. Summary of shipboard results, Hole U1415P. Cored intervals are shaded gray. "Others" includes sand and drilling-induced disaggregated gabbro cuttings (in Core 345-U1415P-2G). Inclination of magnetic remanence (only well-constrained values) and $P$-wave velocity were measured on discrete shipboard samples. Note that the horizontal scale for orthopyroxene (Opx) percentage is logarithmic. TS $=$ shipboard thin sections.

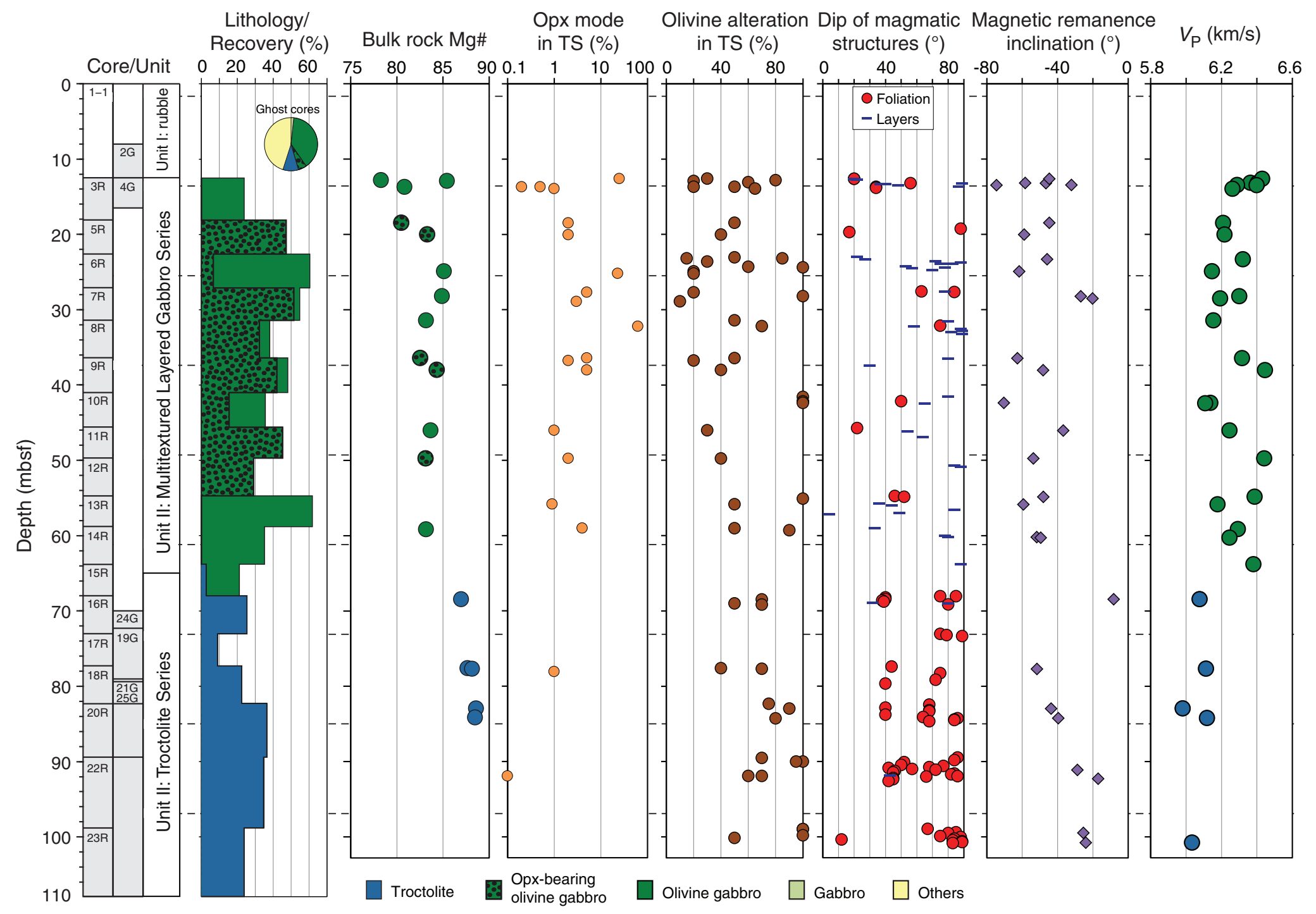


Figure F12. Relative proportions of igneous lithologies at Site U1415 excluding rubble units and ghost cores (Units II and III from Holes U1415I, U1415J and U1415P).

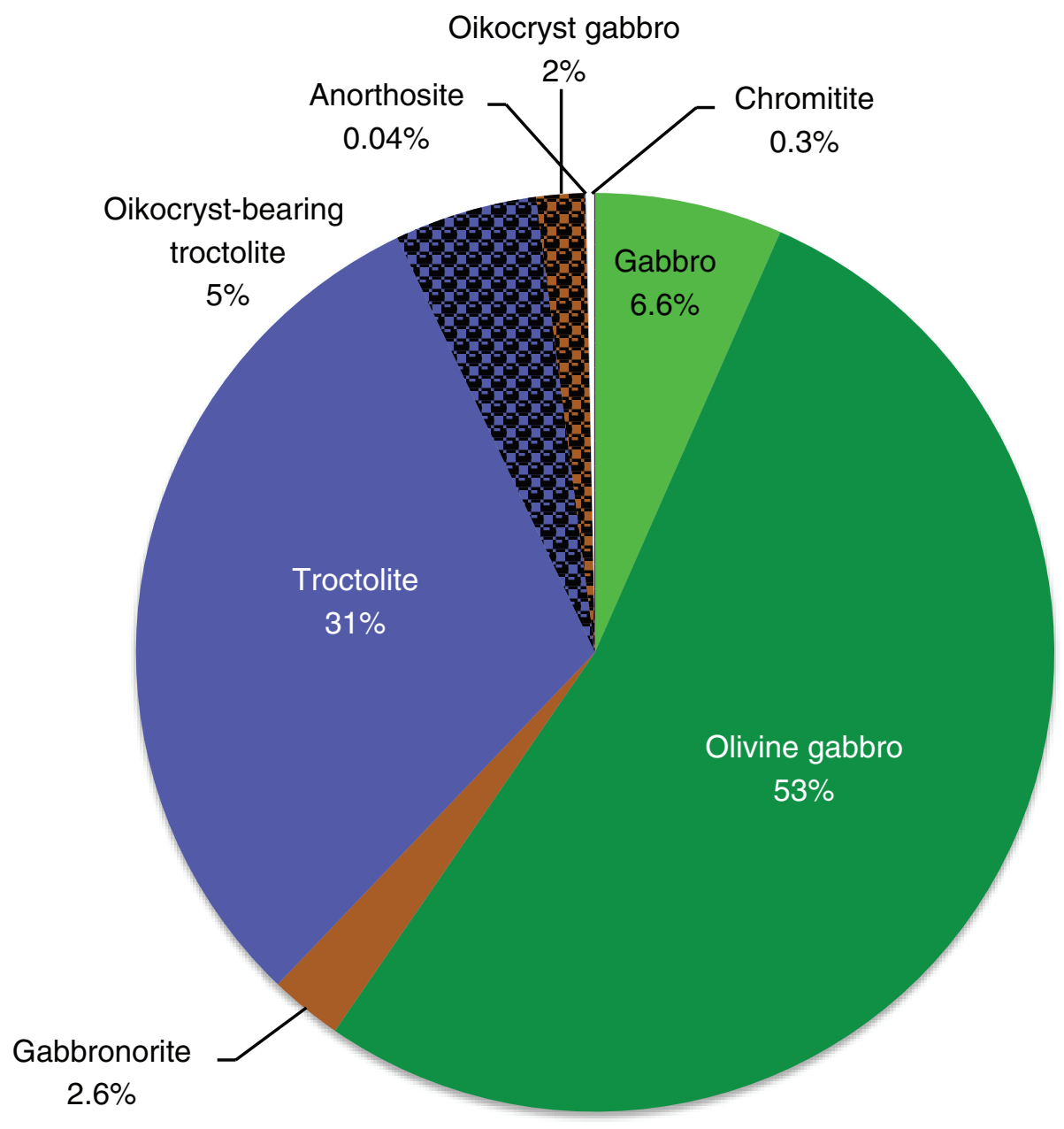


Figure F13. Inclination variation with depth of high unblocking temperature components of magnetization in discrete samples, Holes U1415J and U1415P. Data from Hole U1415J show a downhole change from an upper unit with downward-directed magnetization to a lower unit with upward-directed magnetization, suggesting sampling of two blocks that have been inverted relative to each other. More extensive data from Hole U1415P allow definition of statistically different mean inclinations from petrologically defined Units II (Multitextured Layered Gabbro Series) and III (Troctolitic Series), again consistent with sampling of two blocks with independent rotation histories.
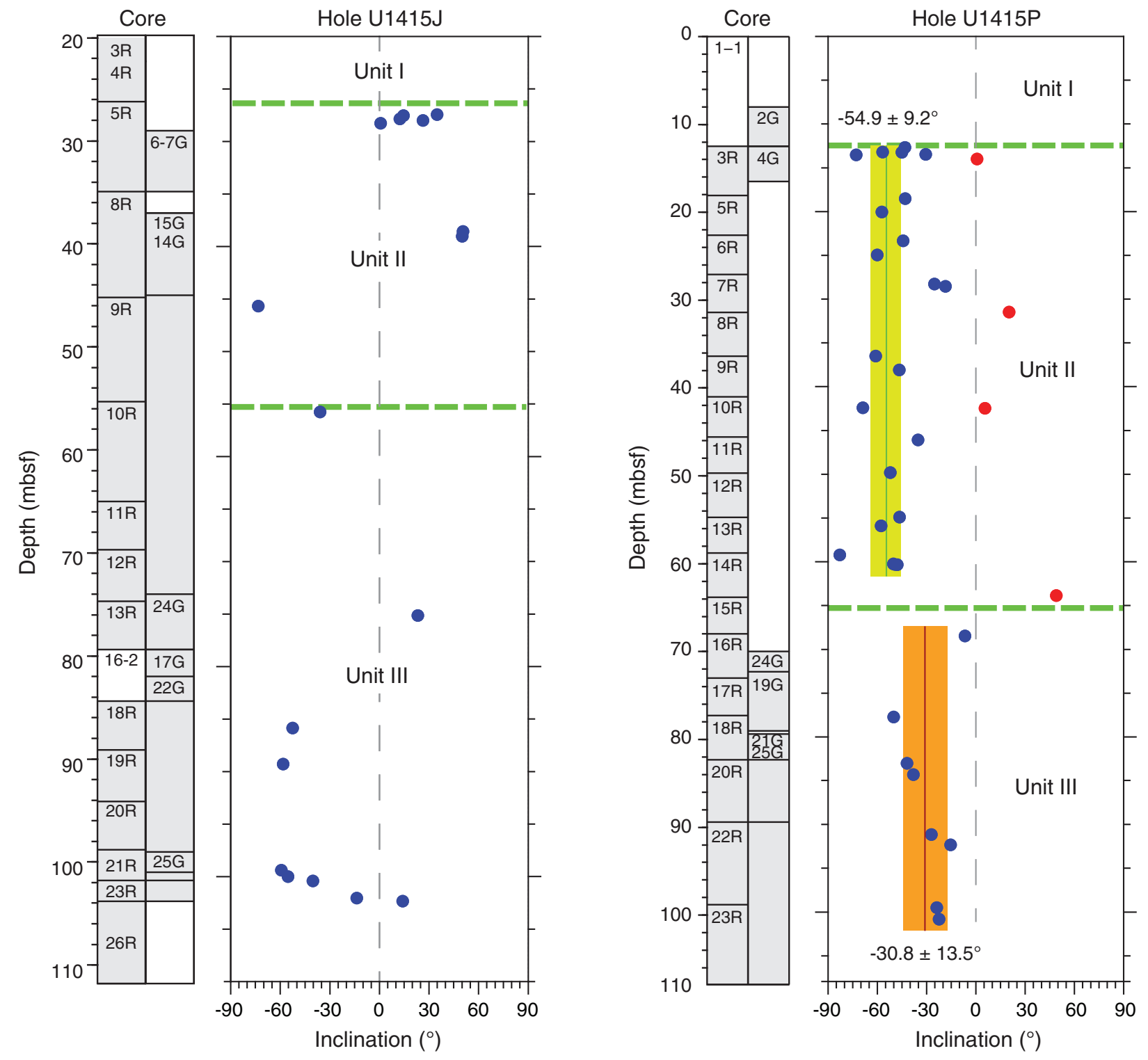
Figure F14. Summary of sampled major lithologic units, Holes U1415I, U1415J and U1415P.

\begin{tabular}{|c|c|}
\multicolumn{1}{c}{ Hole U1415I } \\
Unit & Name \\
\hline I & $\begin{array}{c}\text { Rubble } \\
(0-27.0 \text { mbsf })\end{array}$ \\
\hline II & Layered \\
& Gabbro \\
& $(27.0-35.2$ mbsf $)$ \\
\hline
\end{tabular}

\begin{tabular}{|c|c|}
\multicolumn{1}{c}{ Hole U1415J } \\
Unit & $\begin{array}{c}\text { Name } \\
\text { I }\end{array}$ \\
\hline II & $\begin{array}{c}\text { Rubble } \\
\text { Oikocryst-Bearing } \\
\text { Layered Gabbro } \\
\text { Series } \\
\text { (26.2-55.3 mbsf })\end{array}$ \\
\hline III & Troctolite Series \\
& (55.3-111.8 mbsf) \\
\hline
\end{tabular}

\begin{tabular}{|c|c|}
\hline \multicolumn{2}{|r|}{ Hole U1415P } \\
\hline Unit & Name \\
\hline I & $\begin{array}{c}\text { Rubble } \\
\text { (0-12.5 mbsf) }\end{array}$ \\
\hline II & $\begin{array}{l}\text { Multitextured } \\
\text { Layered } \\
\text { Gabbro Series } \\
\text { (12.5-64.2 mbsf) }\end{array}$ \\
\hline III & $\begin{array}{l}\text { Troctolite Series } \\
\text { (64.2-107.9 mbsf) }\end{array}$ \\
\hline
\end{tabular}


Figure F15. Lithostratigraphy and core recovery, Holes U1415I, U1415J, and U1415P. The different tones of yellow-shaded regions between columns identify lithologic units interpreted to be correlative. See text for details. Opx = orthopyroxene.
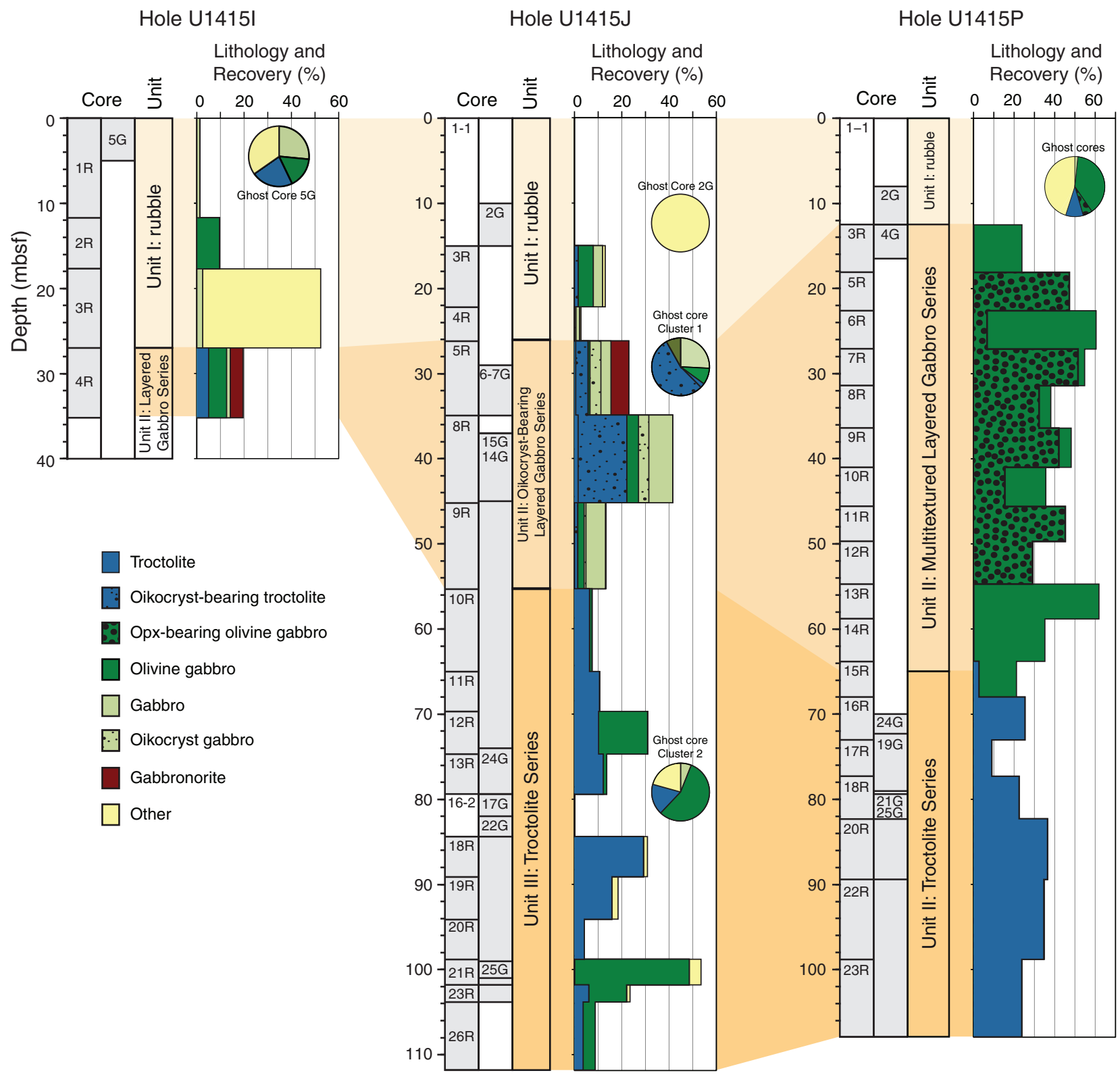
Figure F16. Summary of shipboard results, Hole U1415I. Cored intervals are shaded gray. "Others" includes drilling-induced disaggregated gabbro in Core 345-U1415I-3R and completely altered felsic material in ghost Core 5R. TS = thin section.

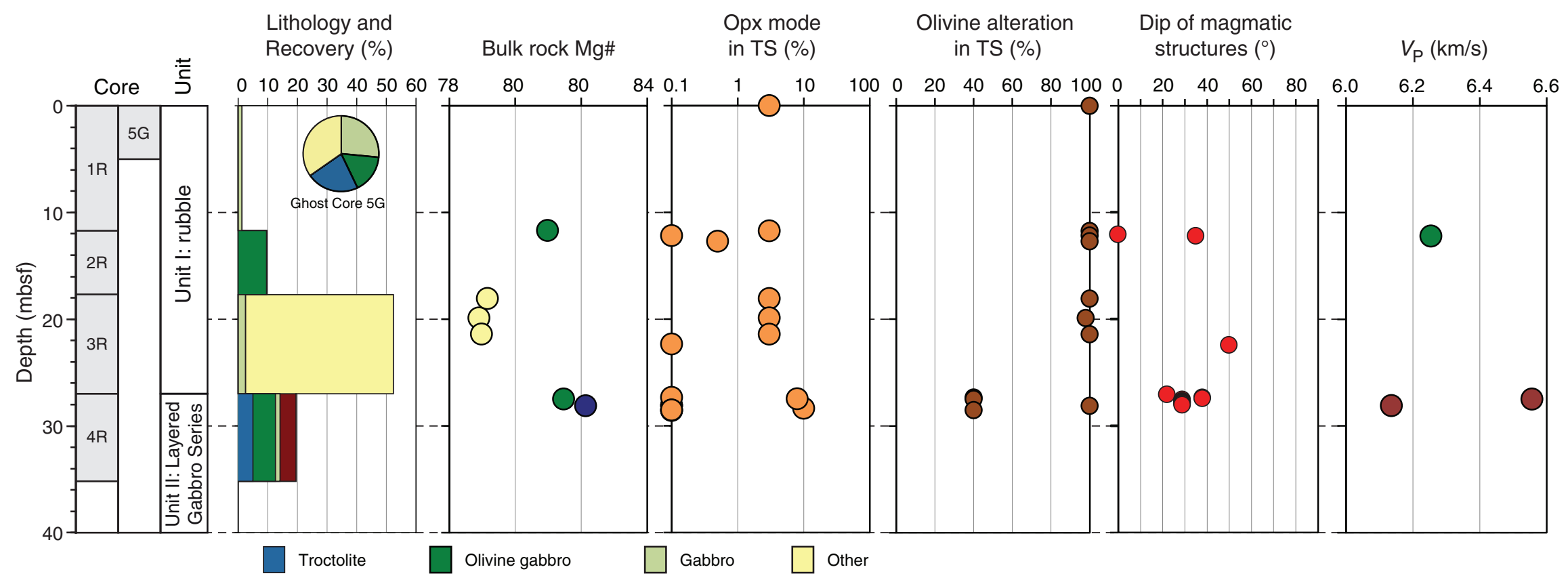


Figure F17. Sutured boundary (red dashed lines) between gabbro and olivine gabbro intervals in the OikocrystBearing Layered Gabbro Series, Hole U1415J. The boundary is defined by differences in grain size and modal mineralogy (Sample U1415J-8R-3, 31-41 cm [Piece 7]). A. Close-up core image. B, C. Thin Section 54; 35-38 cm (Piece 7) under (B) plane-polarized and (C) crossed polars.
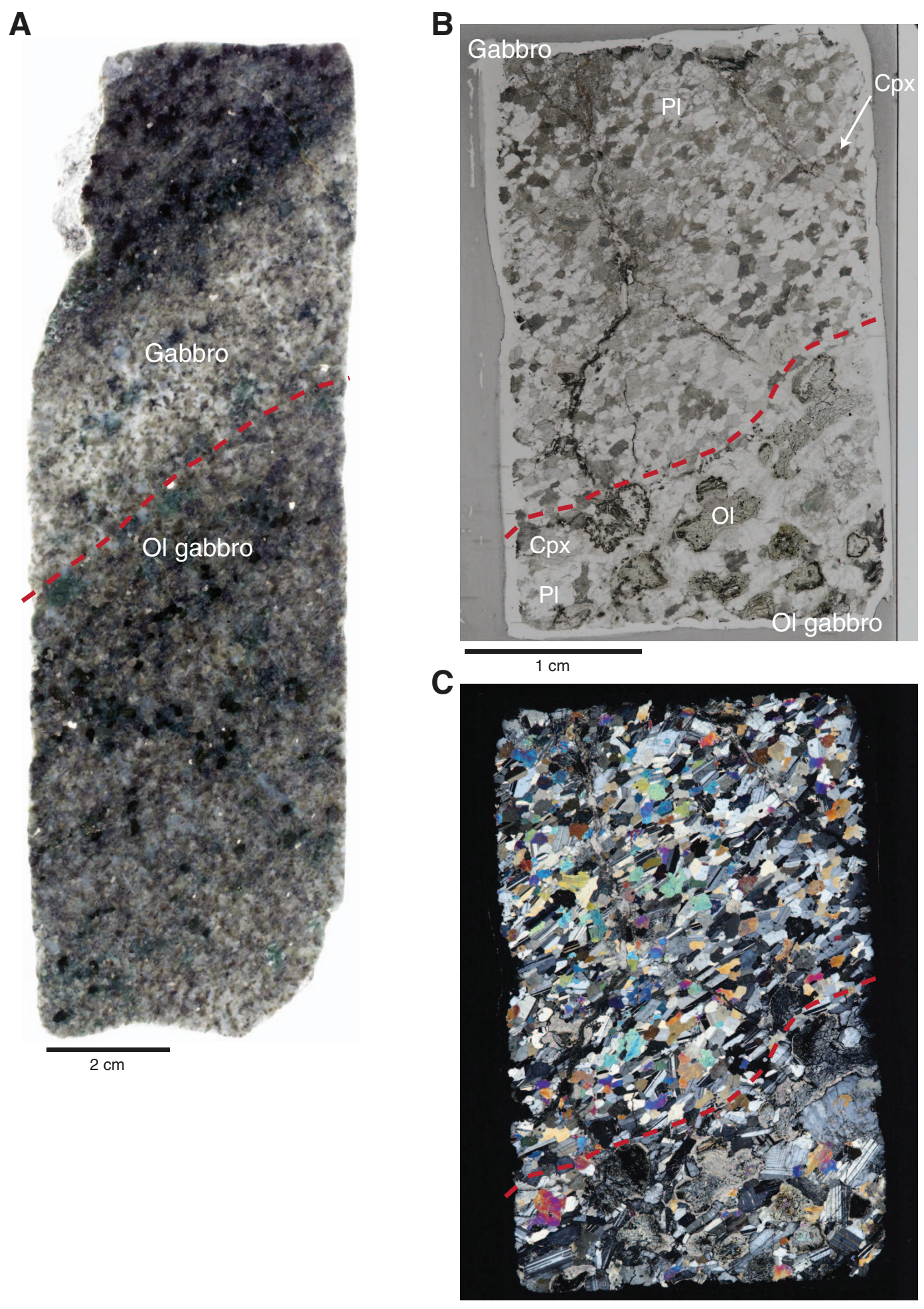

$1 \mathrm{~cm}$ 


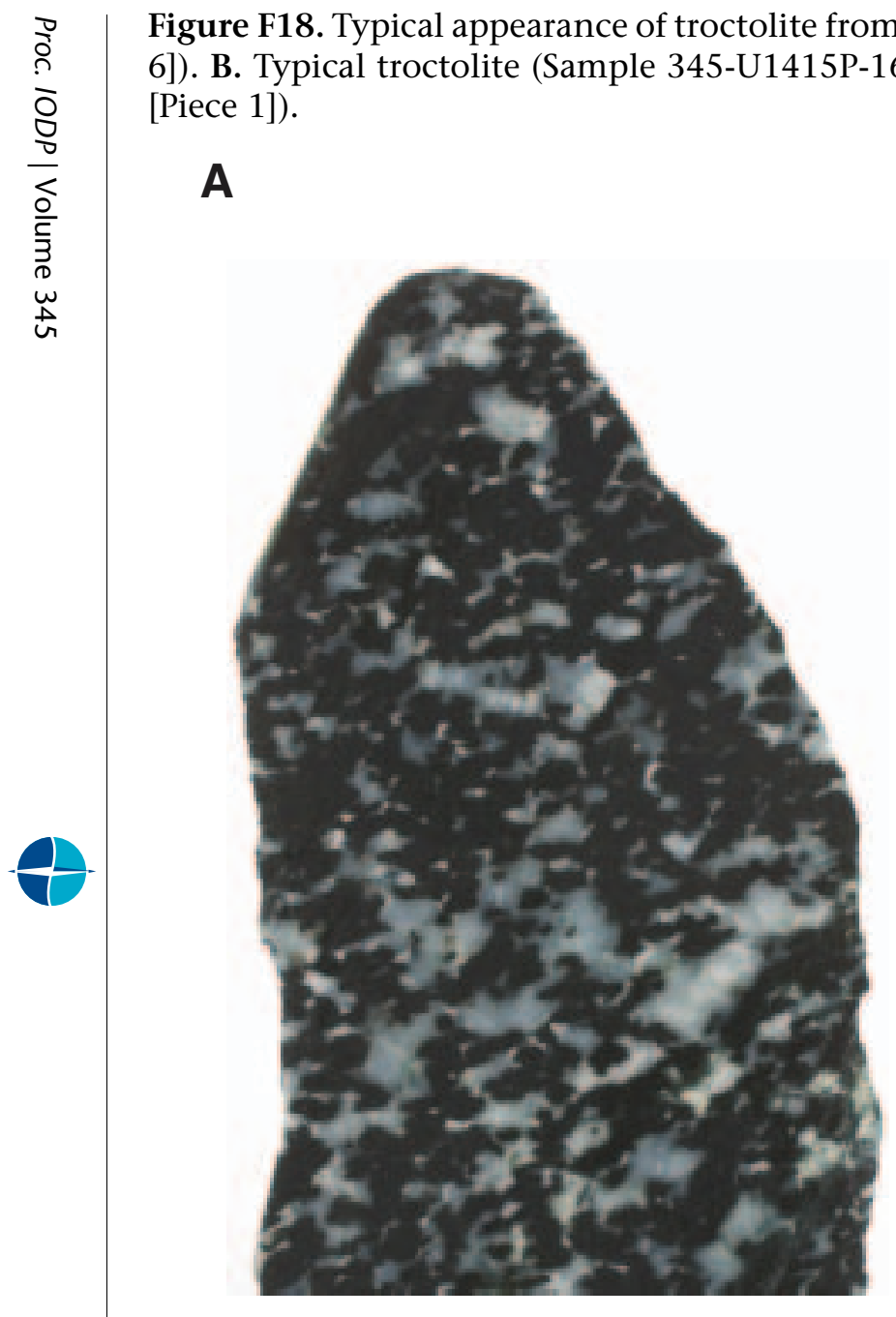

\section{B}

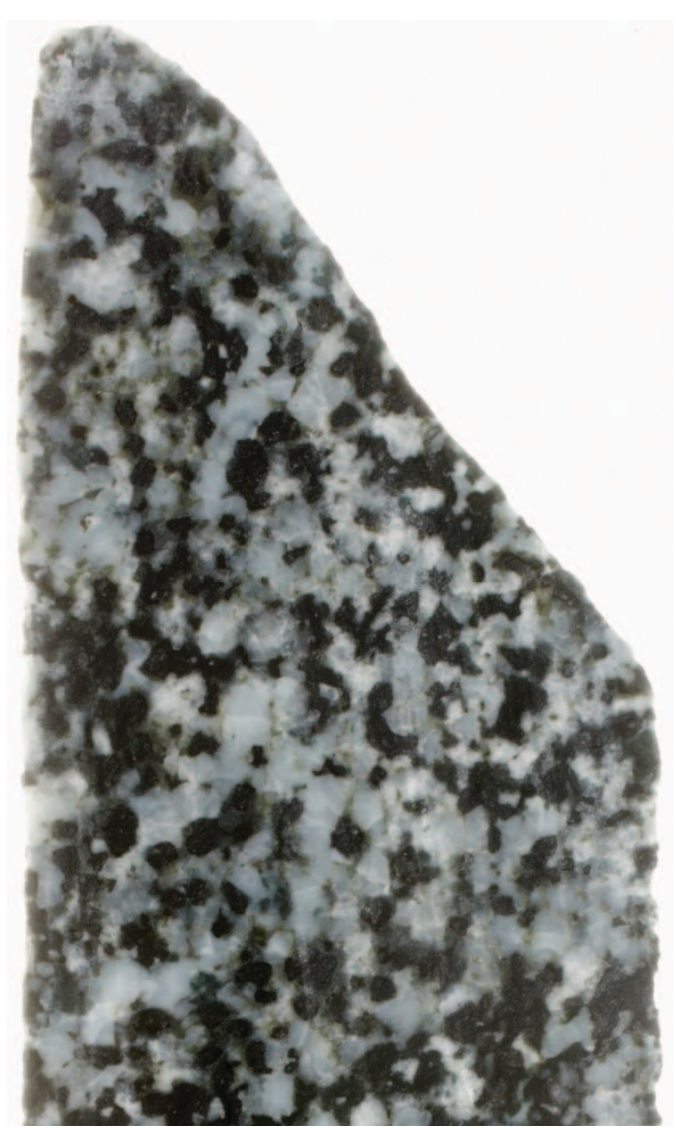

C

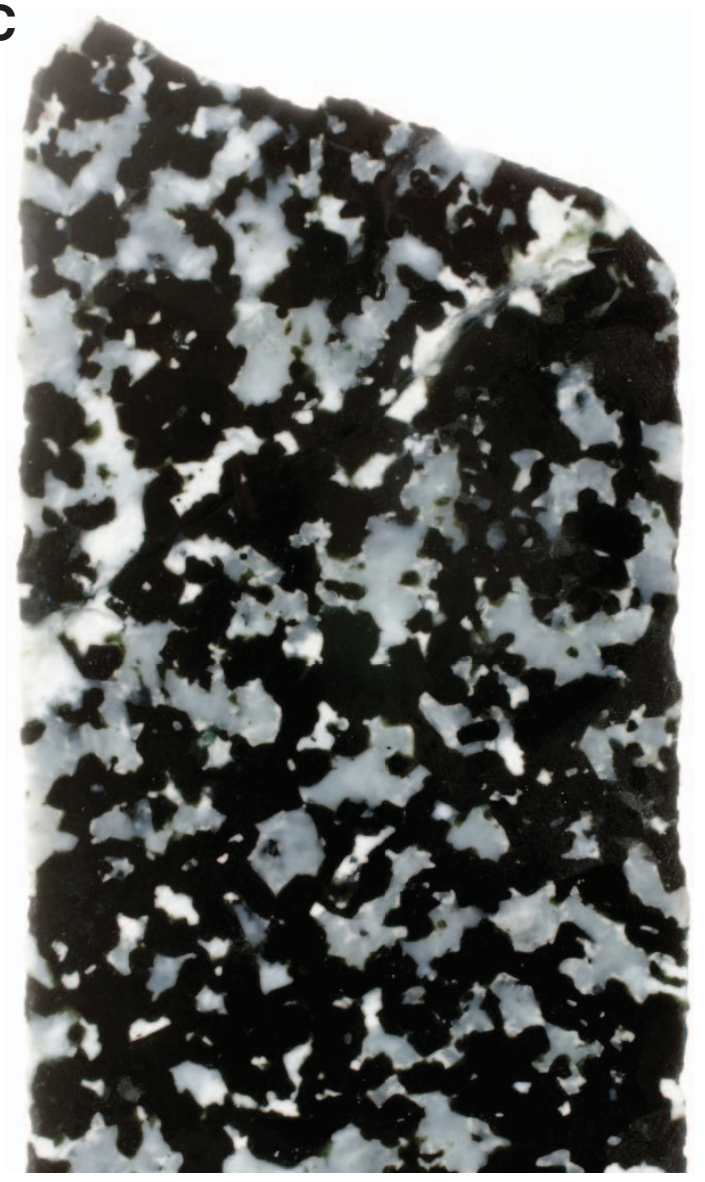


Figure F19. A. Olivine-bearing gabbronorite (Sample 345-U1415I-4R-1, 48-50 cm [Piece 8a]). Red box indicates the location of the thin sections shown in B, C. B. Plane-polarized light. C. Under crossed polars. Note the subparallel alignment of tabular plagioclase and clinopyroxene following the foliation of the rock in B and C. Cpx = clinopyroxene $\mathrm{Ol}=$ olivine, $\mathrm{Opx}=$ orthopyroxene .
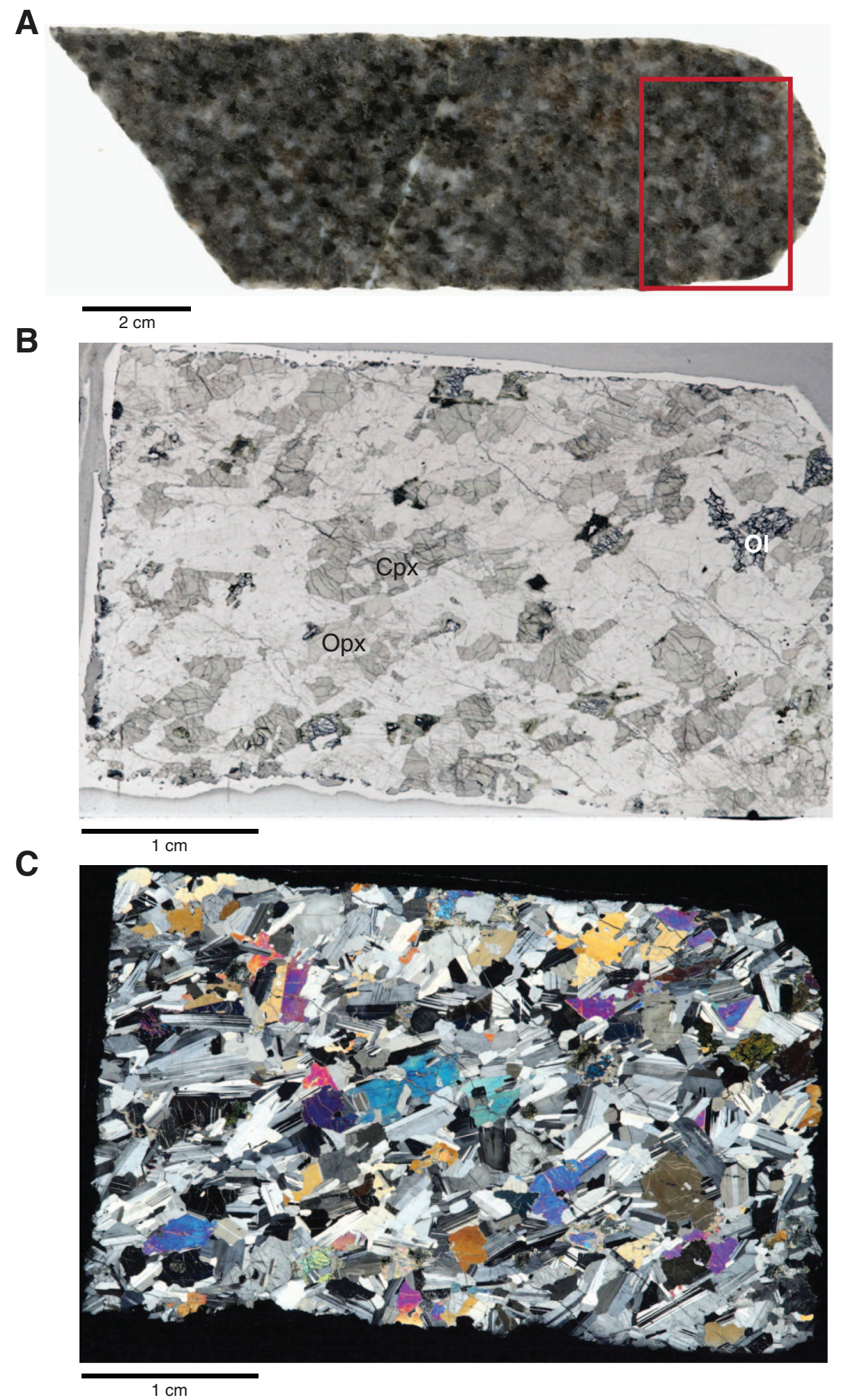
Figure F20. Orthopyroxene-bearing olivine gabbro illustrating the crystallization order for olivine (Ol), orthopyroxene (Opx), plagioclase, and clinopyroxene (Cpx) (Thin Section 118; Sample 345-U1415P-9R-1, 36-41 cm [Piece 3]). A. Plane-polarized light. B. Under crossed polars. White boxes indicate the locations of C and D. C. Skeletal olivine $(\mathrm{Ol})$ is intergrown with orthopyroxene (gray) and plagioclase. D. Late clinopyroxene (orange) is interstitial to all phases.
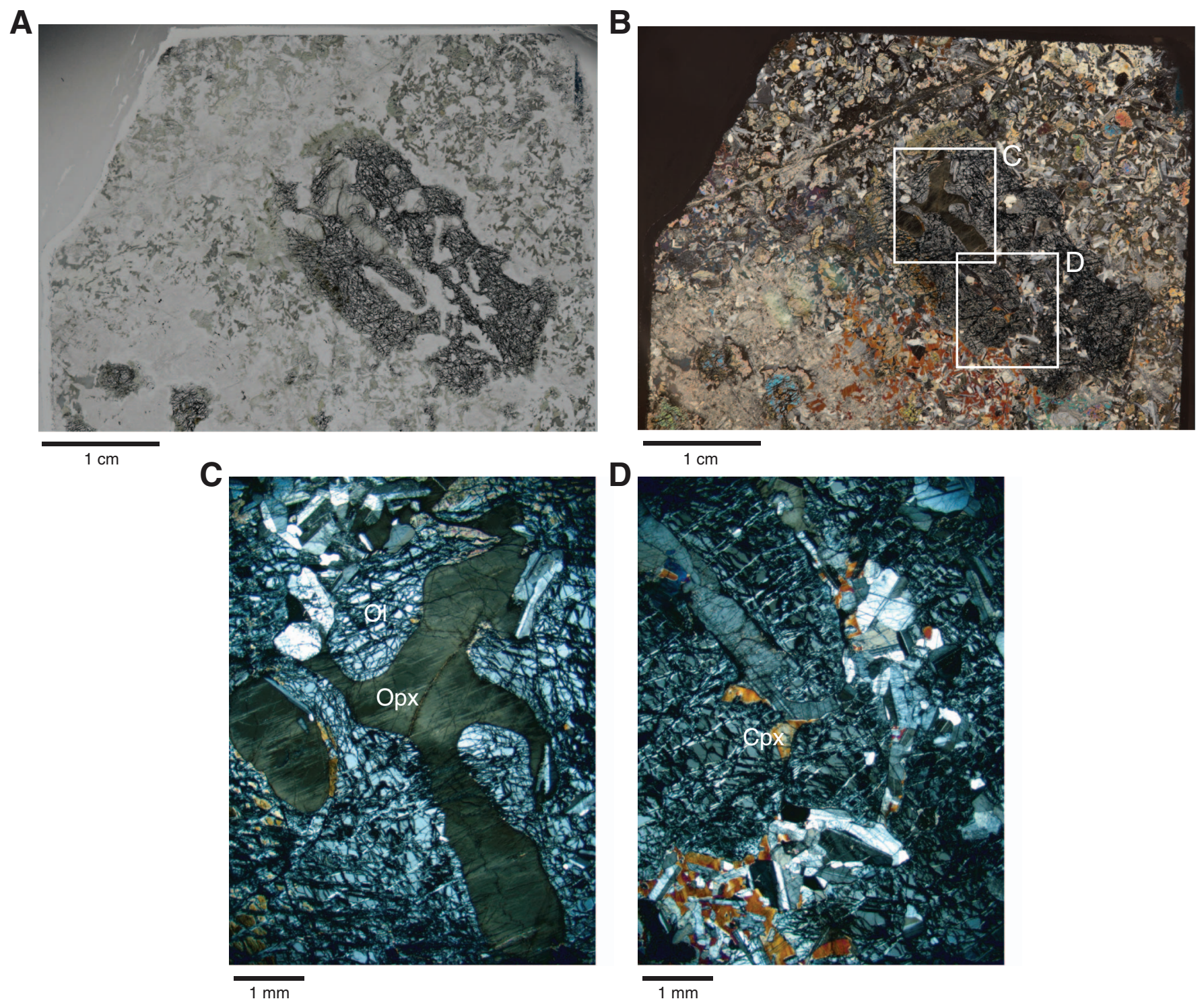
Figure F21. Mineral textures in the layered series, Site U1415. A. Clinopyroxene oikocryst-bearing troctolite (Sample 345-U1415J-8R-3, 79-91 cm [Piece 4B]). White box in the core image shows location of the thin section photomicrograph to the right which shows a large clinopyroxene oikocryst in the lower left. B. Close-up of skeletal olivine (white arrow) in a coarse-grained, multitextured orthopyroxene-bearing olivine gabbro (Sample 345-U1415P-10R-1 [Piece 7, 56-69 cm]). Photomicrograph on far right shows skeletal olivine in a medium-grained troctolite (Sample 345U1415J-10R-1 [Piece 6b, 53-55 cm]).

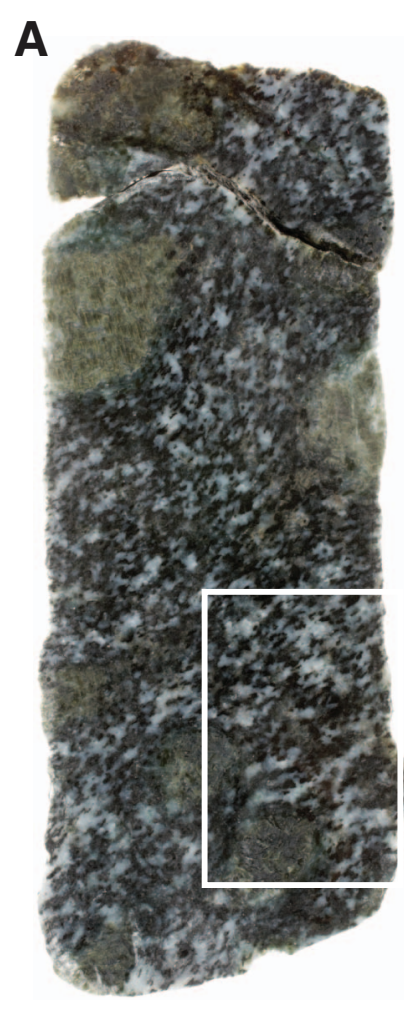

$2 \mathrm{~cm}$

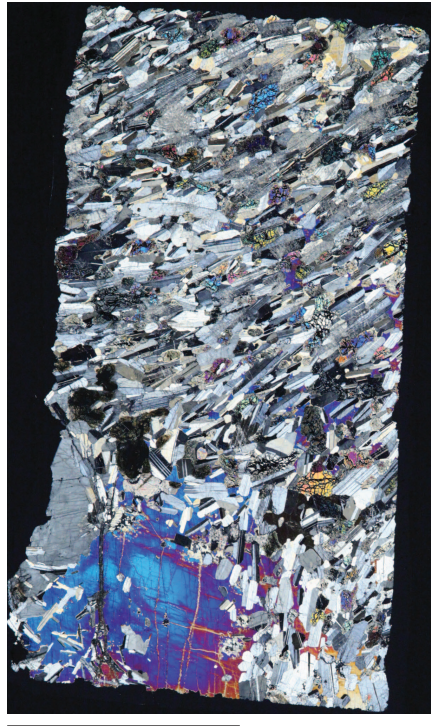

$1 \mathrm{~cm}$
B

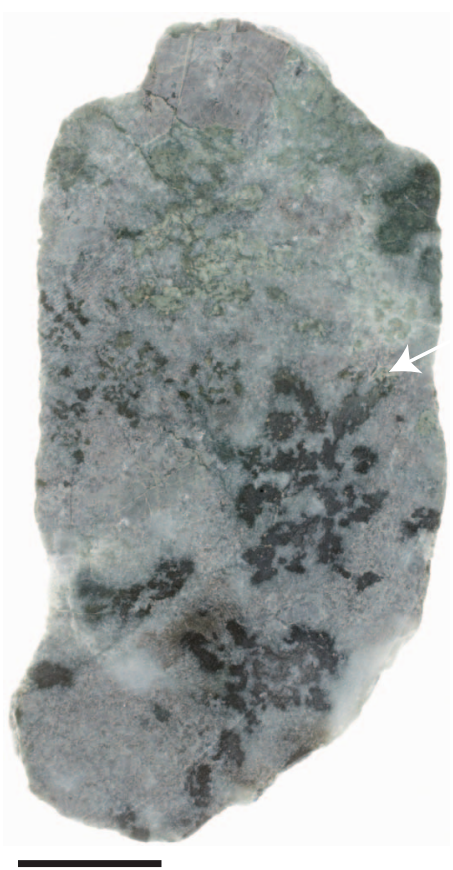

$2 \mathrm{~cm}$

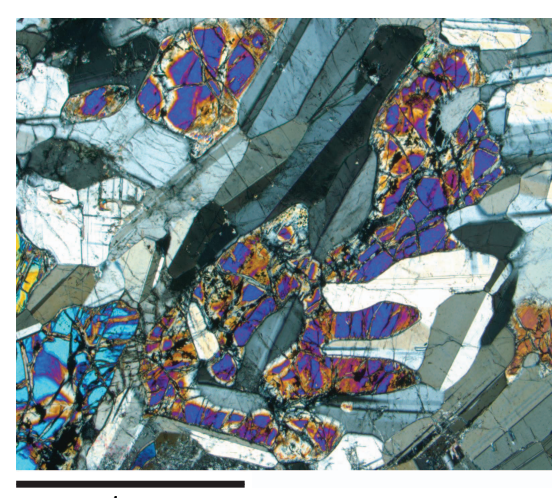

$1 \mathrm{~mm}$ 
Figure F22. A. Clinopyroxene oikocryst-bearing troctolite (Sample 345-U1415J-8R-3, 23-29 cm [Piece 5]). B, C. Clinopyroxene oikocryst-bearing troctolite (Thin Section 53; Sample 345-U1415J-8R-3, 23-29 cm [Piece 5]) showing the strongly foliated troctolite with a single large clinopyroxene oikocryst with abundant randomly orientated subhedral to resorbed deformed to undeformed plagioclase chadacrysts. $\mathrm{Ol}=$ olivine, $\mathrm{Cpx}=$ clinopyroxene, $\mathrm{Pl}=$ plagioclase. $\mathrm{B}$ is under plane-polarized light; $\mathrm{C}$ is under crossed polars.

\section{A}

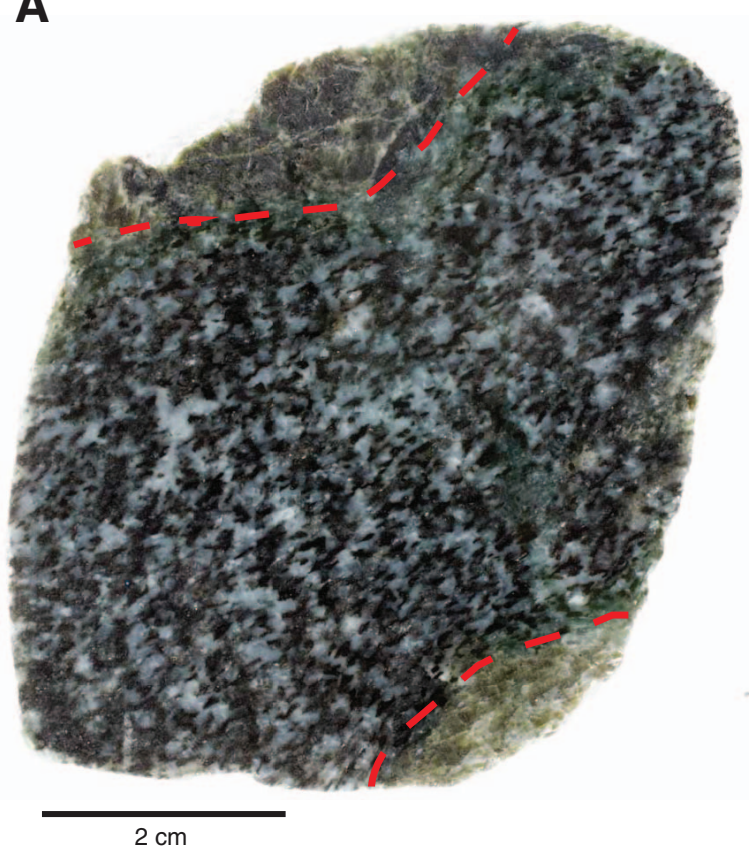

B

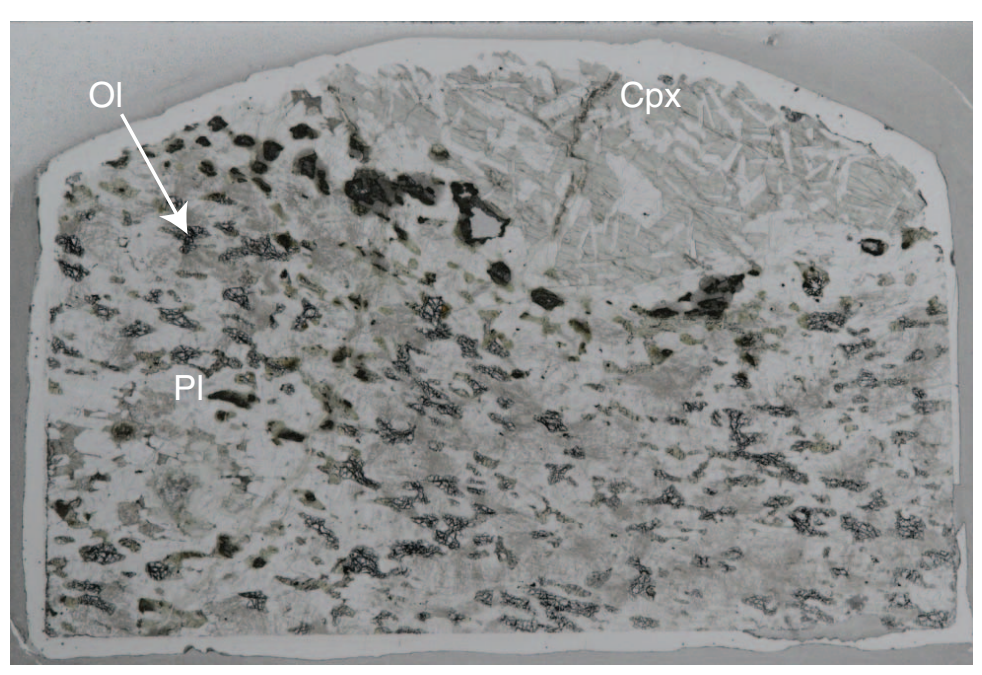

C

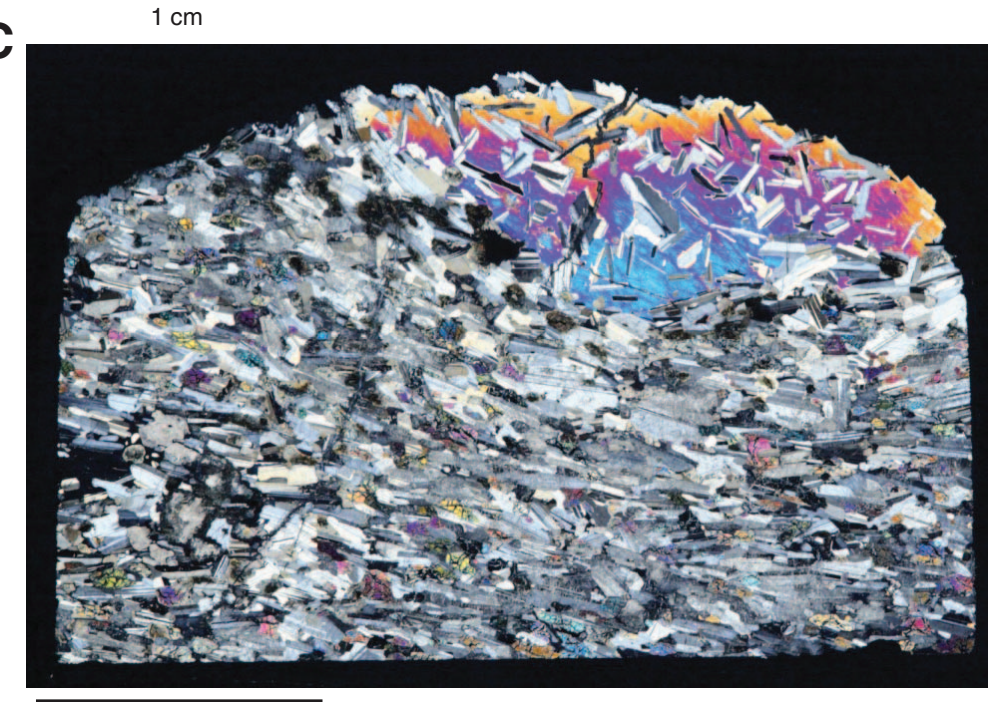

$1 \mathrm{~cm}$ 
Figure F23. Compositions of Cr vs. Mg\# in gabbroic rock, Site U1415. For comparison, a compilation of the plutonic rock sampled from Hess Deep (Hékinian et al., 1993; Gillis, Mével, Allan, et al., 1993; Miller et al., 1996; Natland and Dick, 1996; Pedersen et al., 1996; Hanna, 2004; Kirchner and Gillis, 2012), Pito Deep (Perk et al., 2007), and other locations (Saunders et al., 1982) along the East Pacific Rise (EPR) is shown.

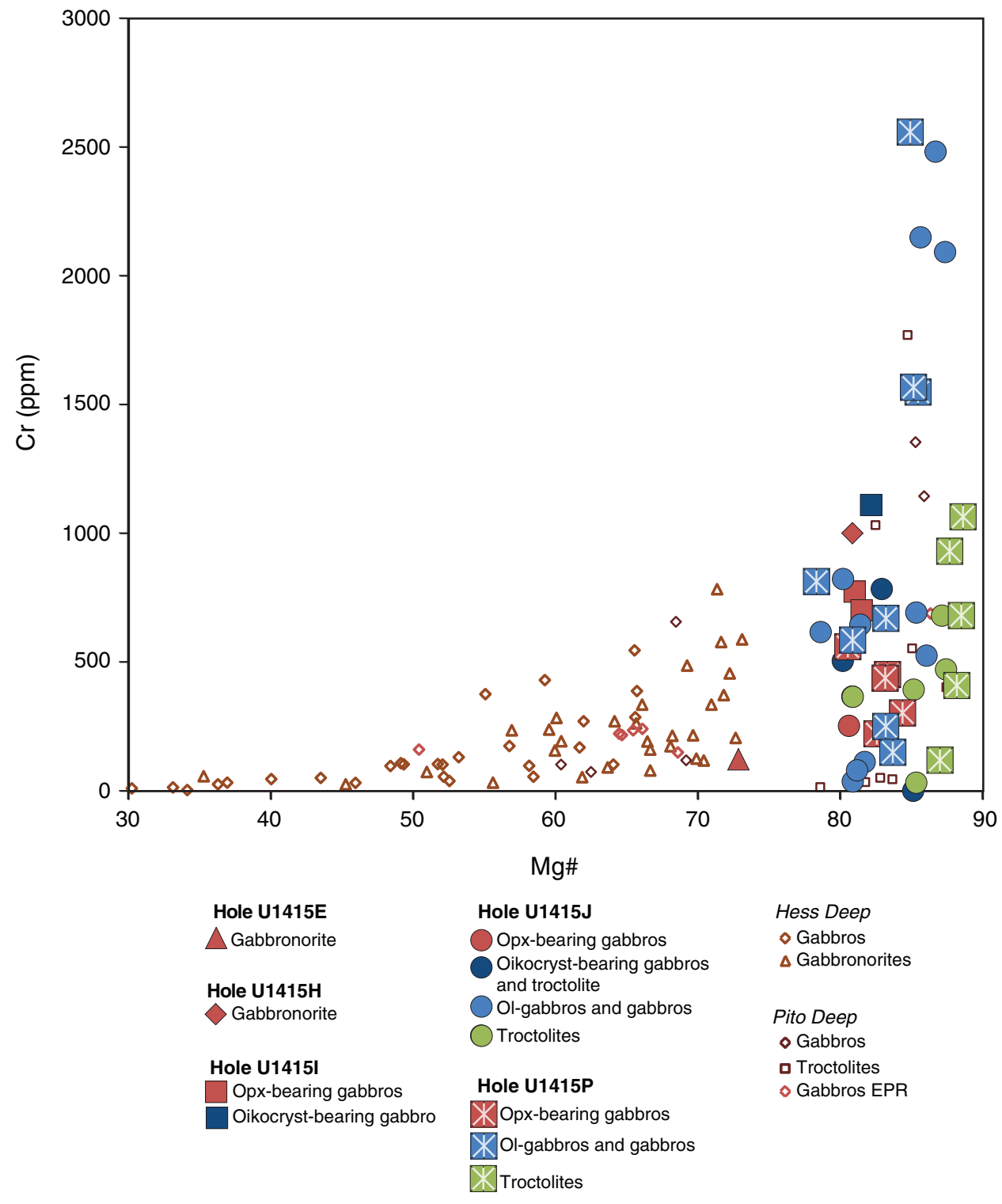


Figure F24. Variability of olivine and plagioclase replacement across different lithologies, Site U1415. Cpx = clinopyroxene, $\mathrm{Chl}=$ chlorite, $\mathrm{Ol}=$ olivine, $\mathrm{Pl}=$ plagioclase, $\mathrm{Pr}=$ prehnite, $\mathrm{Serp}=$ serpentine. $\mathrm{A}$. Olivine gabbro showing radial cracks in plagioclase interpreted as resulting from the apparent volume increase associated with serpentinization of olivine (Thin Section 21; Sample 345-U1415I-4R-1, 35-38 cm [Piece 6]) B. Similar olivine alteration in olivine gabbro in the Multitextured Layered Gabbro Series (Unit II), Hole U1415P. Coronitic textures are moderately well developed, but clinopyroxene and plagioclase are nearly fresh (Thin Section 96; Sample 345-U1415P-3R-1, 113-115 cm [Piece 7]). C. Complete pseudomorphic replacement of plagioclase in association with strongly serpentinized olivine and prehnite veins in the Troctolitic Series (Unit III), Hole U1415P. Coronitic textures are absent from these relict olivine grains. (Thin Section 140; Sample 345 U1415P22R-1, 113-115 cm [Piece 7]).
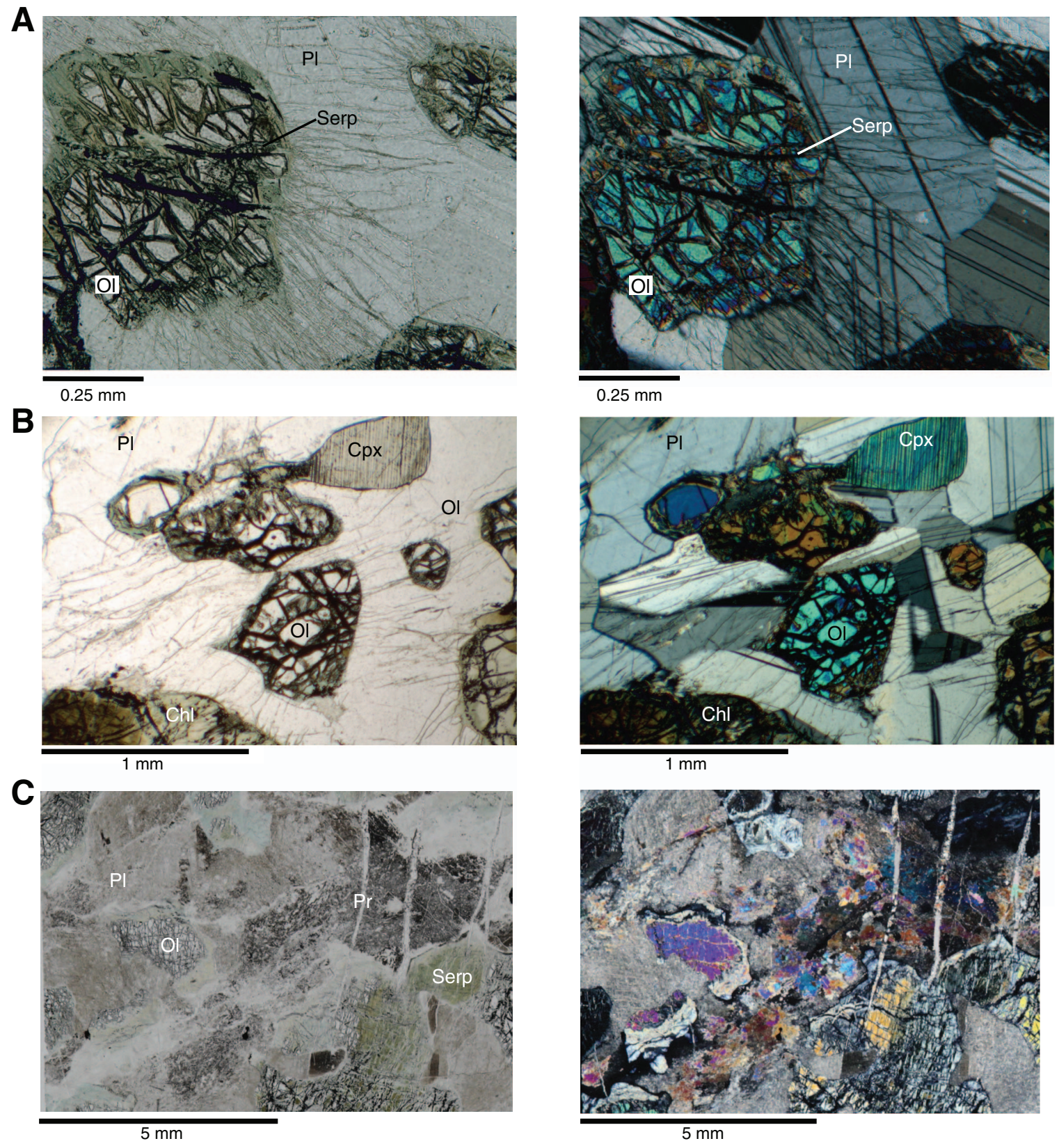
Figure F25. Styles of magmatic layering and foliation in the layered series, Holes U1415J and U1415P. A. Simple centimeter-scale modal layering with an olivine-bearing gabbronorite layer between a troctolite layer at the top and a second, thin troctolite layer in turn overlying an olivinebearing gabbro layer at the bottom. Olivine-plagioclase magmatic foliation subparallel to the layering is also evident (Sample 345-U1415J-5R-2, $2.0-17.5 \mathrm{~cm}$ [Piece 1]). B. Simple centimeter-scale modal layering consisting of a $2 \mathrm{~cm}$ thick olivine-bearing gabbro layer within a clinopyroxene oikocryst-bearing troctolite layer (Sample 345-U1415J-8R-2, 105.5-121.0 cm [Piece 9]). C. Diffuse subvertical (in the core reference frame) banding in orthopyroxene-bearing olivine gabbro (Sample 345-U1415P-8R-2, 0-16 cm [Piece 1]).
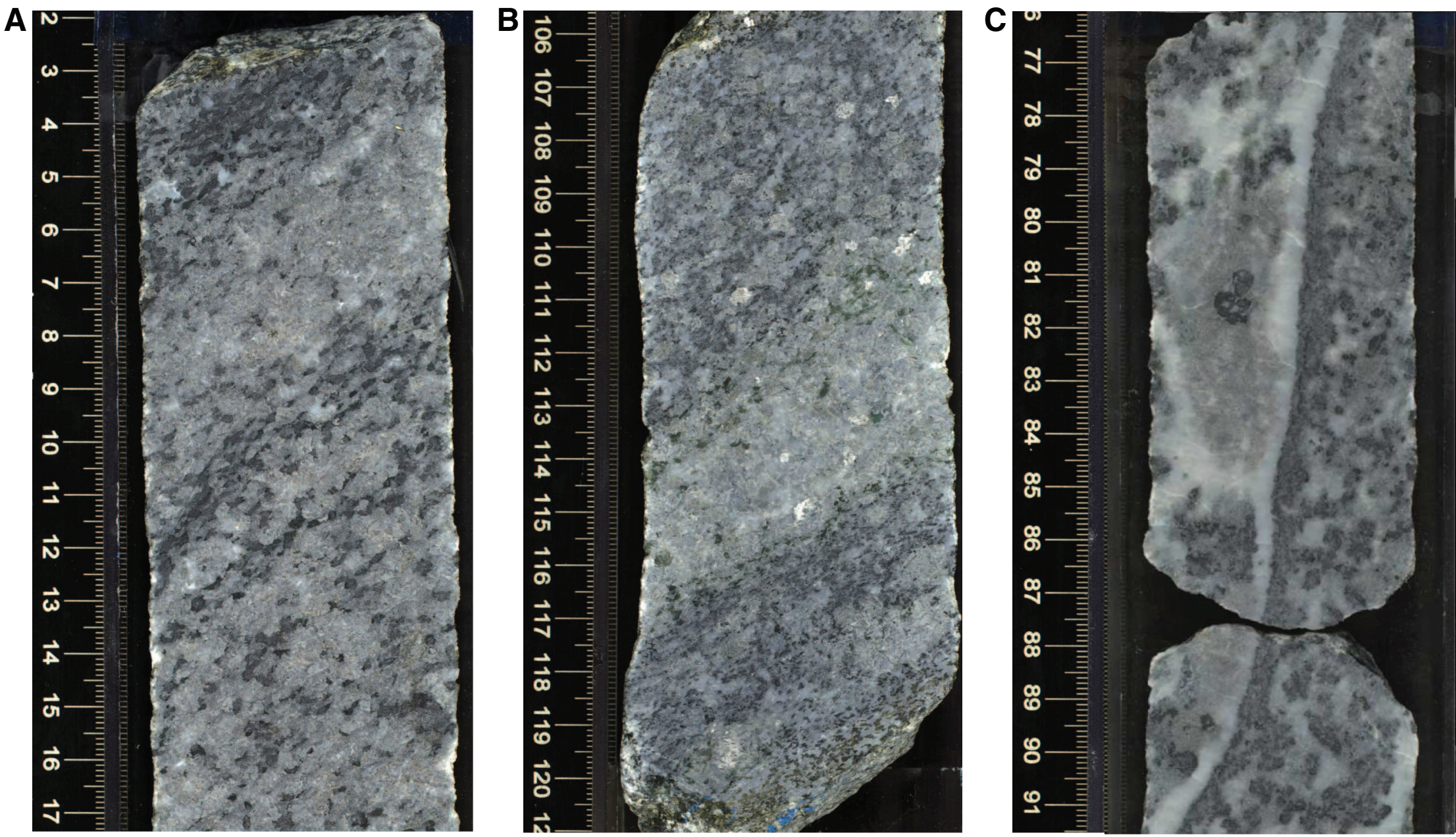
Figure F26. Conditions for representative background alteration mineral assemblages in Site U1415 gabbroic rock. Temperature conditions are estimated from thermodynamic calculations of reaction curves using simplified bulk compositions. Reaction curves were drawn using the TWQ software (version 2.3) with database version 1.02 (Berman, 1991). Dotted curves = displacement caused by the substitution of Mg by Fe in mafic minerals coexisting with $\mathrm{Fo}_{80}$ olivine, calculated using the distribution coefficients of Evans and Trommsdorff (1974). Because of the lack of appropriate constraints, pressure conditions were inferred from the assumption that gabbros originated at mid- to lower crustal depths and were exposed at the present position by a tectonic event under low-temperature conditions. This uncertainty is indicated by the question marks on the vertical scale. A. $\mathrm{CaO}-\mathrm{Al}_{2} \mathrm{O}_{3}-\mathrm{SiO}_{2}-\mathrm{H}_{2} \mathrm{O}$ system with additional reactions forming prehnite + chlorite assemblage. $\mathbf{B}$. CaO-MgO-Al $\mathrm{O}_{3}-\mathrm{SiO}_{2}-\mathrm{H}_{2} \mathrm{O}$ system (modified after Nozaka and Fryer, 2011).
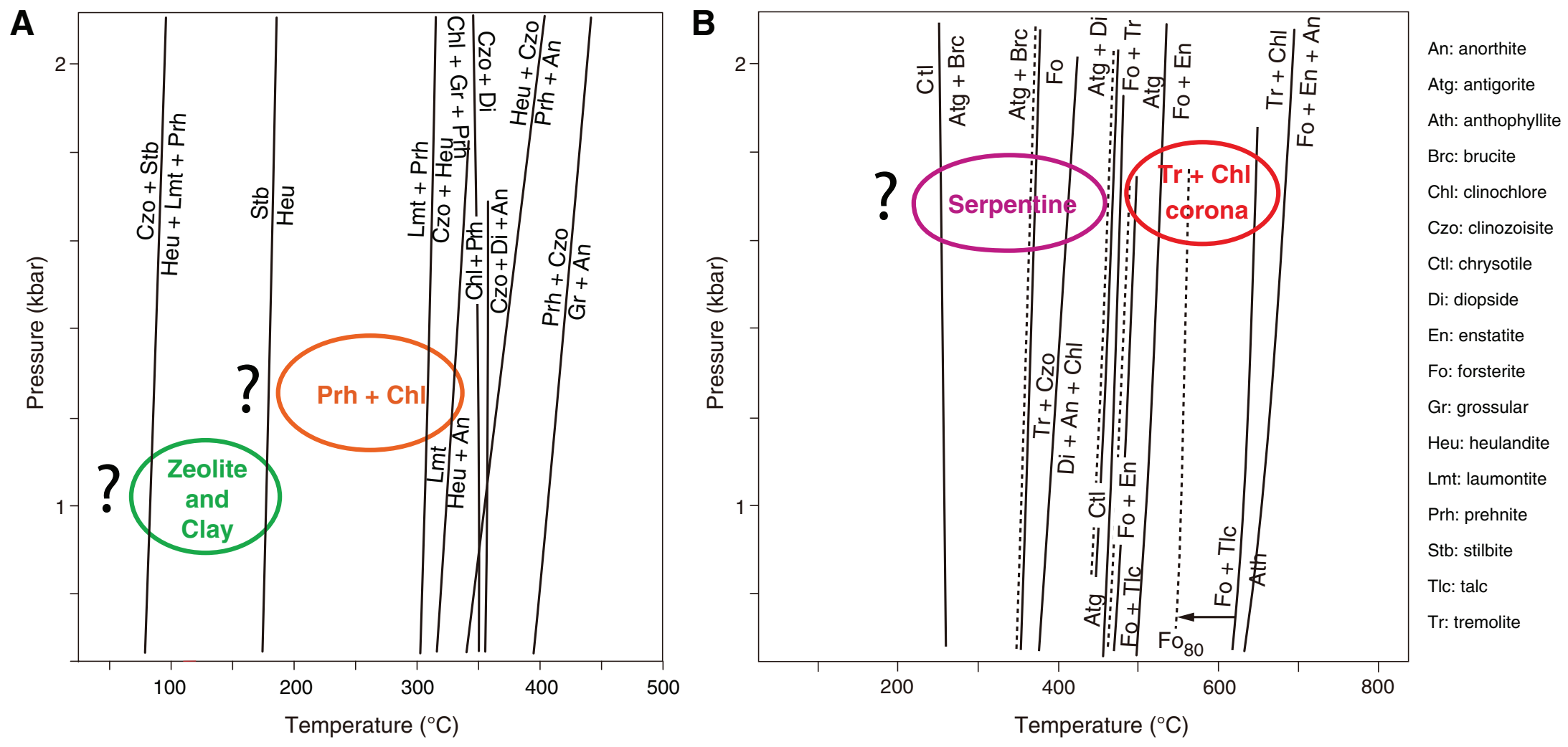
Figure F27. Examples of high-quality thermal demagnetization data, Site U1415. A. Most samples displayed stable, high unblocking temperature components of magnetization after removal of drilling-induced components by low-temperature demagnetization (LTD) and of lower temperature components (probably related to alteration in some samples). B. Several samples from Hole U1415J were found to hold complex remanences consisting of two or three nearly antipodal components, suggesting that magnetization was acquired in different geomagnetic polarity periods. Blue arrow = drilling-induced magnetization, red/orange/green arrows = high/middle/low unblocking temperature components, solid circles = projection on to the horizontal plane, open circles = projection on to the vertical Y-Z plane. Inset is equal-area stereographic projection in B (solid/ open symbols = lower/upper hemisphere).

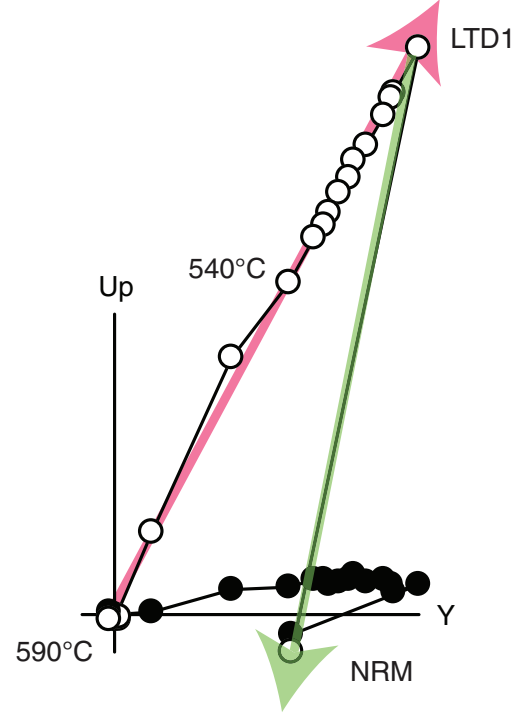

Troctolitic olivine gabbro 345-U1415P-6R-2, $92 \mathrm{~cm}$ $\mathrm{NRM}=906 \mathrm{~m} / \mathrm{Am}$

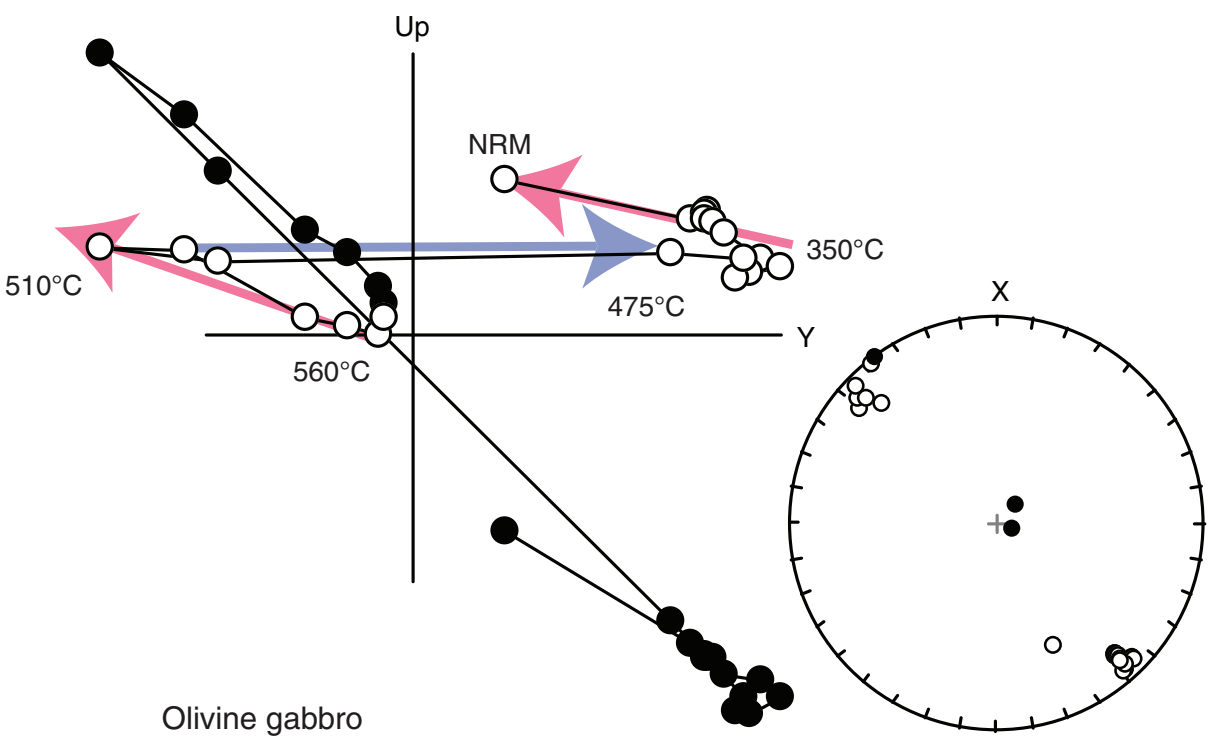

345-U1415J-23R-1, $22 \mathrm{~cm}$

$\mathrm{NRM}=3.2 \mathrm{~m} / \mathrm{Am}$ 
Table T1. Operations summary, Expedition 345.

\begin{tabular}{|c|c|c|c|c|c|c|c|c|}
\hline Hole & Location & $\begin{array}{l}\text { Water } \\
\text { depth } \\
\text { (mbsl) }\end{array}$ & $\begin{array}{c}\text { Total } \\
\text { penetration } \\
\text { (mbsf) }\end{array}$ & $\begin{array}{l}\text { Interval } \\
\text { cored } \\
(\mathrm{m})\end{array}$ & $\begin{array}{l}\text { Core } \\
\text { recovery* } \\
(\mathrm{m})\end{array}$ & $\begin{array}{l}\text { Core } \\
\text { recovery } \\
(\%)\end{array}$ & $\begin{array}{l}\text { Time } \\
\text { on hole } \\
\text { (d) }\end{array}$ & Operations \\
\hline U1415A & $2^{\circ} 15.1757^{\prime} \mathrm{N}, 101^{\circ} 32.5695^{\prime} \mathrm{W}$ & 4837 & 10.3 & - & - & - & 1.2 & Jet-in test \\
\hline U1415B & $2^{\circ} 15.1355^{\prime} \mathrm{N}, 101^{\circ} 32.8671^{\prime} \mathrm{W}$ & 4845 & 11.7 & - & - & - & 0.2 & Jet-in test \\
\hline U1415C & $2^{\circ} 15.1349^{\prime} \mathrm{N}, 101^{\circ} 32.8669^{\prime} \mathrm{W}$ & 4845 & \multicolumn{4}{|c|}{ BHA bent during penetration } & 0.8 & Jet-in test; bent $\mathrm{BHA}$ \\
\hline U1415D & $2^{\circ} 15.1437^{\prime} \mathrm{N}, 101^{\circ} 32.7441^{\prime} \mathrm{W}$ & 4840 & 4.2 & - & - & - & 0.7 & Jet-in test \\
\hline U1415E & $2^{\circ} 15.1461^{\prime} \mathrm{N}, 101^{\circ} 32.7424^{\prime} \mathrm{W}$ & 4840 & 15.3 & 15.3 & 0.84 & 5 & 1.1 & $\mathrm{RCB}$ coring \\
\hline U1415F & $2^{\circ} 15.1394^{\prime} \mathrm{N}, 101^{\circ} 32.6261^{\prime} \mathrm{W}$ & 4846 & 1.5 & - & - & - & 0.8 & Jet-in test \\
\hline U1415G & $2^{\circ} 15.1390^{\prime} \mathrm{N}, 101^{\circ} 32.6263^{\prime} \mathrm{W}$ & 4846 & 12.9 & 12.9 & 0.29 & 2 & 0.3 & $\mathrm{RCB}$ coring \\
\hline U1415H & $2^{\circ} 15.1317^{\prime} \mathrm{N}, 101^{\circ} 32.6370^{\prime} \mathrm{W}$ & 4846 & 12.9 & 12.9 & 0.44 & 3 & 1.0 & $\mathrm{RCB}$ coring \\
\hline U1415I & $2^{\circ} 15.1547^{\prime} \mathrm{N}, 101^{\circ} 32.6622^{\prime} \mathrm{W}$ & 4842 & 35.2 & 35.2 & 7.12 & 20 & 2.9 & $\mathrm{RCB}$ coring \\
\hline U1415] & $2^{\circ} 15.1604^{\prime} \mathrm{N}, 101^{\circ} 32.6622^{\prime} \mathrm{W}$ & 4839 & 111.8 & 91.8 & 14.35 & 16 & 16.0 & Installed nested FFFs and casing to $15 \mathrm{mbsf}$; RCB coring \\
\hline U1415K & $2^{\circ} 15.3307^{\prime} \mathrm{N}, 101^{\circ} 32.8527^{\prime} \mathrm{W}$ & 4687 & 35.3 & - & - & - & 3.6 & Failed attempt to establish reentry capability \\
\hline U1415L & $2^{\circ} 15.3300^{\prime} \mathrm{N}, 101^{\circ} 32.8041^{\prime} \mathrm{W}$ & 4675 & 4.0 & - & - & - & 0.7 & Jet-in test \\
\hline U1415M & $2^{\circ} 15.3304^{\prime} \mathrm{N}, 101^{\circ} 32.8040^{\prime} \mathrm{W}$ & 4675 & 25.9 & - & - & - & 2.6 & Failed attempt to establish reentry capability \\
\hline U1415N & $2^{\circ} 15.3304^{\prime} \mathrm{N}, 101^{\circ} 32.8121^{\prime} \mathrm{W}$ & 4675 & 37.0 & 37.0 & 1.56 & 4 & 2.1 & $\mathrm{RCB}$ coring \\
\hline U14150 & $2^{\circ} 15.1516^{\prime} \mathrm{N}, 101^{\circ} 32.5848^{\prime} \mathrm{W}$ & 4850 & 17.0 & - & - & - & 1.2 & Failed attempt to establish reentry capability \\
\hline \multirow[t]{2}{*}{ U1415P } & $2^{\circ} 15.1486^{\prime} \mathrm{N}, 101^{\circ} 32.6102^{\prime} \mathrm{W}$ & 4853 & 107.9 & 95.4 & 30.57 & 32 & 10.6 & $\begin{array}{l}\text { Installed FFF and casing to } 12.5 \mathrm{mbsf} ; \mathrm{RCB} \text { coring; failed } \\
\text { attempt to log }\end{array}$ \\
\hline & & Total*: & 442.9 & 300.5 & 55.17 & 18 & 45.9 & \\
\hline
\end{tabular}

${ }^{*}=$ excludes cores recovered during hole cleaning operations (ghost cores). $-=$ no data. $\mathrm{RCB}=$ rotary core barrel. $\mathrm{BHA}=$ bottom-hole assembly. $\mathrm{FFF}=$ free-fall funnel. 